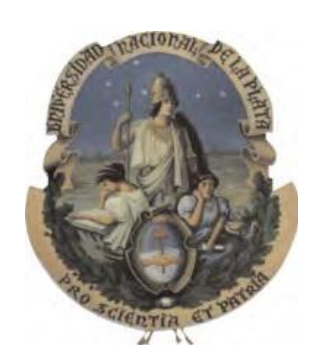

Universidad Nacional de La Plata

Facultad de Ciencias Exactas

Departamento de Ciencias Biológicas

Tesis Doctoral

\title{
Regulación Fisiológica del Cotransportador Sodio/Bicarbonato Cardíaco
}

\section{Alejandro Orlowski}

\author{
Director \\ Dr. Ernesto Alejandro Aiello \\ Profesor adjunto de la Cátedra de Fisiología y Biofísica \\ Facultad de Ciencias Médicas, UNLP. \\ Investigador Independiente (CONICET) \\ Codirector \\ Dr. Bernardo Víctor Álvarez \\ Jefe de Trabajos Prácticos de la Cátedra de Fisiología y Biofísica \\ Facultad de Ciencias Médicas, UNLP. \\ Investigador Independiente (CONICET)
}




\section{Agradecimientos}

A mi Director Alejandro, por su esfuerzo y dedicación, su amistad y confianza, quien con sus conocimientos, su experiencia, su ejemplo y su motivación ha logrado incrementar en mí la búsqueda constante de respuestas y la formulación de nuevas preguntas.

A mi Codirector Bernardo, por su predisposición, sus apreciados y relevantes aportes, críticas, comentarios y sugerencias. Por sus consejos a nivel científico y aún más importante a nivel personal.

A la Dra. Alicia Mattiazzi, por darme la oportunidad de formar parte del Centro de Investigaciones Cardiovasculares.

Al Dr. Martin Vila-Petroff, por permitirme finalizar mi trabajo de tesis doctoral en el Centro de Investigaciones Cardiovasculares.

A la Dra. Verónica Milesi, por aceptar ser mi asesora científica.

Al Dr. Horacio Cingolani, por dejarme participar en las reuniones permitiéndome escuchar y aprender de su experiencia y conocimiento; contribuyendo así de mi formación profesional.

Al Dr. Patricio Morgan, por su contagioso entusiasmo y sus incontables aportes científicos fundamentales para la realización de la tesis.

A Vero, Caro, Luis, Ale, Gisel, Gus por su paciencia, inagotable alegría, por las interminables conversaciones distendidas y la generosa amistad que me demuestran día a día.

A todos los integrantes del centro de investigaciones cardiovasculares, Alba, Mónica, Mariano, Margarita, Irene, Ines, Omar, Cecilia, Omin, Romina, Marisa, Nacho, Celeste, Susana, Luisa, Juliana, Alejandra, Constanza, Leandro, Matilde, Leticia, Bárbara, Julieta, Charly, Ezequiel, Luciana, Soledad, Mariela, Lorena, Malena, Juan, Ema, Juan, Pini, Leandro, Lucia, Paola, porque todos contribuyeron, inclusive sin saberlo, en la realización del presente trabajo de tesis.

A mis amigos, por su sincero afecto, consejos, charlas e infinitos momentos divertidos.

A mi familia porque sin su apoyo incondicional y su enorme cariño jamás hubiera podido alcanzar mis objetivos.

A Rocío, porque un día decidiste tomarme la mano y jamás soltarla, recorriendo la vida juntos cumpliendo cada uno de nuestros proyectos.

A todos ellos simplemente gracias por ser parte de este momento tan importante en mi vida. 
A mi familia.

Al amor de mi vida.

A mis amigos. 


\section{Lista de publicaciones derivadas de esta tesis}

\section{Revistas}

Orlowski A, De Giusti VC, Morgan PE, Aiello EA, Álvarez BV. "Binding of Carbonic Anhydrase IX to Extracellular Loop 4 of the $\mathrm{NBCe} 1 \mathrm{Na}^{+} / \mathrm{HCO}_{3}{ }^{-}$Cotransporter Enhances $\mathrm{NBCe1-mediated} \mathrm{HCO}_{3}{ }^{-}$ Influx in the Rat Heart" Am J Physiol Cell Physiol. 2012 Jul; 303(1):C69-80.

Orlowski A, Vargas LA, Aiello EA, Álvarez BV. "Elevated carbon dioxide upregulates NBCn1 $\mathrm{Na}^{+} / \mathrm{HCO}_{3}{ }^{-}$cotransporter in human embryonic kidney cells" Am J Physiol Renal Physiol. 2013 (En prensa).

\section{Congresos}

"Interacción física y funcional de la anhidrasa carbónica con la isoforma electrogénica NBC1 del cotransportardor $\mathrm{Na}^{+} / \mathrm{HCO}_{3}{ }^{-}$cardíaco" Orlowski A, De Giusti VC, Álvarez BV, Aiello EA. Reunión Científica Anual de la Sociedad Argentina de Fisiología. La Plata, Argentina 15-16/10/2009.

"Interacción física y funcional de la anhidrasa carbónica con la isoforma electrogénica NBC1 del cotransportardor $\mathrm{Na}^{+} / \mathrm{HCO}_{3}{ }^{-}$cardíaco" Orlowski A, De Giusti VC, Álvarez BV, Aiello EA. XXIII Congreso de la Asociación Latinoamericana de Ciencias Fisiológicas. Pucón, Chile 1620/11/2009.

"Physical and functional coupling of electrogenic $\mathrm{Na}^{+} / \mathrm{HCO}_{3}$ cotransport and carbonic anhydrases in the myocardium" Orlowski A, De Giusti VC, Aiello EA, Álvarez BV. 54 meeting Biophysical society. San Francisco, EEUU 20-24/02/2010.

"El transporte de bicarbonato endógeno de las células de riñón embrionarias HEK293 es mediado por el cotransporte $\mathrm{Na}^{+} / \mathrm{HCO}_{3}^{-}$electroneutro (NBCn1) y es modulado por la concentración de $\mathrm{CO}_{2}$ " Orlowski A, Alvarez BV, Aiello EA. Reunión Científica Anual 2011 de la Sociedad Argentina de Fisiología. Mar del Plata, Argentina 16-19/11/2011.

"La Aldosterona estimula al cotransportador $\mathrm{Na}^{+} / \mathrm{HCO}_{3}{ }^{-}$cardíaco por un mecanismo no genómico y dependiente de especies reactivas del oxígeno" Orlowski A, Ciancio MC, Aiello EA. Congreso Argentino de Hipertensión Arterial. Buenos Aires, Argentina 12-14/04/2012.

"Aldosterone mediates the cardiac sodium/bicarbonate (NBC) activation through a nongenomic and ROS-dependent mechanism" Orlowski A, Ciancio MC, De Giusti VC, Aiello EA. XXI World Congress of the international society of heart research. San Diego, EEUU 30/0604/07/2013. 
Índice

Abreviaturas

Lista de figuras

8

Lista de tablas

I El cotransportador $\mathrm{Na}^{+} / \mathrm{HCO}_{3}{ }^{-}$cardíaco

I.1 Regulación del $\mathrm{pH}_{\mathrm{i}}$ cardíaco

I.2 El Cotransportador $\mathrm{Na}^{+} / \mathrm{HCO}_{3}{ }^{-}$(NBC)

I.3 Estructura

I.4 Regulación

I.5 Fisiología y fisiopatología del NBC cardíaco

II Regulación física del cotransportador NBCe1 por la anhidrasa carbónica IX

II.1 Introducción

II.2 Anhidrasa Carbónica IX

II.3 Metabolón de transporte lónico

II.4 Objetivo 1

II.5 Evidencia experimental de la interacción física de la anhidrasa carbónica IX y el cotransportador electrogénico NBCe1

Regulación funcional del cotransportador NBCe1 por anhidrasas carbónicas en cardiomiocitos

II.7 Regulación funcional del cotransportador NBCe1 por las anhidrasas carbónicas en un sistema de expresión heterólogo (HEK293)

II.8 Discusión 
III Regulación hormonal del cotransporte $\mathrm{Na}^{+} / \mathrm{HCO}_{3}^{-}$por la aldosterona

III.1 Introducción

III.2 Síntesis de aldosterona

III.3 Efectos rápidos (no genómicos) de la aldosterona

III.4 La aldosterona y el músculo cardíaco

III.5 GPR30

III.6 Objetivo 2

III.7 Activación del cotransporte $\mathrm{Na}^{+} / \mathrm{HCO}_{3}{ }^{-}$cardíaco por la aldosterona

III.8 La aldosterona estimula al NBC por un mecanismo no genómico e independiente de CaMKII

III.9 Las especies reactivas del oxígeno (ERO) como segundos mensajeros del efecto de la aldosterona sobre el NBC

III.10 Participación del receptor GPR30

III.11 Discusión

IV Regulación del cotransporte $\mathrm{NBCn} 1$ por la presión de $\mathrm{CO}_{2}$

IV.1 Introducción

IV.2 Objetivo 3

IV.3 Regulación del pH intracelular en células HEK293

IV.4 Expresión del $\mathrm{NBCn} 1$ en células $\mathrm{HEK} 293$ expuestas altos niveles de $\mathrm{CO}_{2}$

IV.5 Análisis funcional del NBCn1 en células $\mathrm{HEK} 293$ expuestas altos niveles de $\mathrm{CO}_{2}$

IV.6 Discusión 
VI Materiales y Métodos

VI.1 Aislamiento de miocitos cardíacos de rata

VI.2 Cultivo de células embrionarias de riñón humano (HEK293)

VI.3 Determinación de $\mathrm{pH}_{\mathrm{i}}$ por epifluorescencia

Vl.4 Pulso de $\mathrm{NH}_{4}{ }^{+}$en miocitos ventriculares de rata

VI.5 Pulsos de $\mathrm{NH}_{4}{ }^{+}$en células HEK293

VI.6 Despolarización por alto $\mathrm{K}^{+}$

VI.7 Expresión transitoria de ADNc en sistemas heterólogos

VI.8 Análisis de proteínas por Western-Blots (inmunoblots)

VI.9 Coinmunoprecipitaciones

VI.10 Ensayo de GST Pull down

VI.11 Análisis de expresión de proteínas de membrana

VI.12 Determinación de la expresión de transcriptos por RT-PCR

VI.13 Inmunofluorescencia y análisis por microscopía confocal 


\section{Abreviaturas}

\begin{tabular}{|c|c|}
\hline AC & Anhidrasa carbónica \\
\hline AE & Intercambiador $\mathrm{Cl}^{-} / \mathrm{HCO}_{3}{ }^{-}$(intercambiador aniónico) \\
\hline AMPc & Adenosín monofosfato cíclico \\
\hline Atm & Atmosfera \\
\hline Ald & Aldosterona \\
\hline Apo & Apocinina \\
\hline Angll & Angiotensina 2 \\
\hline BCECF-AM & $\begin{array}{l}\text { Acetoximetilester tetra-acetoximetil 2-7’bis (carboxietil)-5(6)carboxi- } \\
\text { fluoresceína }\end{array}$ \\
\hline $\mathrm{CHO}$ & Transportador $\mathrm{Cl}^{-} / \mathrm{OH}^{-}$ \\
\hline ET1 & Endotelina 1 \\
\hline EDTA & Ácido etilendiaminoacético \\
\hline ERO & Especies reactivas del oxígeno \\
\hline EIPA & 5-N-etil-N-isopropilamiloride \\
\hline ERK & Proteína quinasa activada por mitógenos \\
\hline GST & Glutatio-S-Transferasa \\
\hline GPR30 & Receptor de estrógenos asociados a proteína G \\
\hline HEK293 & Células embrionarias de riñón humano \\
\hline HBS & HEPES buffer salino \\
\hline $\mathbf{I P}_{\mathbf{3}}$ & Inositol 3 fosfato \\
\hline MPG & mercapto-propionil-glicina 2 mM \\
\hline NBC & Cotransporte $\mathrm{Na}^{+} / \mathrm{HCO}_{3}^{-}$(sodio/bicarbonato) \\
\hline NHE & Intercambiador $\mathrm{Na}^{+} / \mathrm{H}^{+}$(sodio/próton) \\
\hline NOX & NADPH oxidasa \\
\hline $\mathrm{pH}_{\mathrm{i}}$ & $\mathrm{pH}$ intracelular \\
\hline $\mathrm{pH}_{\mathrm{e}}$ & $\mathrm{pH}$ extracelular \\
\hline PIP2 & Fosfoinositol 2 fosfato \\
\hline PBS & Fosfato buffer salino \\
\hline PAGE & Electroforesis en gel de poliacrilamida \\
\hline PG & Proteoglicano \\
\hline SDS & Dodecil sulfato de sodio \\
\hline SGK1 & Quinasa inducida por Suero/Glucocorticoide \\
\hline
\end{tabular}




\section{Lista de figuras}

I.1 Resumen de los reguladores de $\mathrm{pH}_{\mathrm{i}}$ en cardiomiocitos.

I.2 Análisis filogenético de los mecanismos reguladores de $\mathrm{pH}_{\mathrm{i}}$ en cadiomiocitos.

I.3 Modelo topológico del NBCe1.

I.4 Resumen del efecto dual de la Angiontesina II sobre las isoformas del NBC.

I.5 Esquema del posible efecto deletéreo del NBC.

II.1 Estructura tridimensional de la anhidrasa carbónica IX.

II.2 Mecanismo de acción del metabolón de transporte iónico.

II.3 Coinmunoprecipitaciones de las AC II, IV y IX y el NBCe1 en el corazón de rata.

II.4 Coinmunoprecipitaciones del complejo NBCe1/AC IX en células HEK293.

II.5 Ensayo GST pull down.

II.6 Colocalización por microscopía confocal.

II.7 Pulso de $\mathrm{K}^{+}$en presencia de inhibidores de las anhidrasas carbónicas.

II.8 Pulso de $\mathrm{NH}_{4}{ }^{+}$en presencia de $\mathrm{HOE} 10 \mu \mathrm{M}$ y en ausencia de $\mathrm{HCO}_{3}{ }^{-}$.

II.9 Pulso de $\mathrm{NH}_{4}{ }^{+}$con inhibidores de las anhidrasas carbónicas.

II.10 Recuperación de una sobrecarga ácida en células HEK.

II.11 Recuperación de una sobrecarga ácida en células transfectadas con NBCe1 y AC IX.

II.12 Efecto de la BZ sobre la anhidrasa carbónica intracelular de las HEK293.

II.13 Esquema representativo del metabolón de transporte iónico.

III.1 Esquema de la ruta de síntesis de la aldosterona.

III.2 Efecto de la aldosterona sobre el NHE1 cardíaco.

III.3 Efecto de la aldosterona sobre el NBC cardíaco.

III.4 Evidencia de la identidad molecular del NBCe1 y NBCn1 en miocitos cardíacos.

III.5 Efecto de la aldosterona sobre la isoforma electrogénica NBCe1.

III.6 La Ald estimula al NBC por un efecto no genómico e independiente de CaMKII.

III.7 Participación de las ERO en el efecto de la Aldosterona sobre el NBC cardíaco

III.8 Participación de las ERO en el efecto de la Aldosterona sobre el NBCe1.

III.9 Participación del GPR30 en la vía de señalización mediada por Aldosterona.

III.10 La aldosterona ejerce su acción a través del receptor GPR30.

III.11 La aldosterona a través del GPR30 incrementa la actividad del NBCe1.

III.12 Esquema de la vía de señalización por la cual la aldosterona activa al NBC.

IV.1 Transporte endógeno EIPA-insensible en células HEK293.

IV.2 El transporte EIPA-insensible es dependiente de $\mathrm{HCO}_{3}{ }^{-}$.

IV.3 Transporte endógeno $\mathrm{Na}^{+}$dependiente y $\mathrm{Cl}^{-}$independiente.

IV.4 Sensibilidad al S0859, inhibidor selectivo del NBC.

IV.5 Niveles de expresión endógena de los cotransportadores NBCe1, NBCe2 y NBCn1.

IV.6 Expresión de los transcriptos correspondientes a NBCe1, NBCe2 y NBCn1.

IV.7 La expresión del $\mathrm{NBCn} 1$ se encuentra regulada por el aumento de la presión de $\mathrm{CO}_{2}$.

IV.8 Aumento del transporte mediado por NBC por el incremento de la presión de $\mathrm{CO}_{2}$. 
V.1 Aislamiento de miocitos cardíacos de rata

V.2 Cultivo de células HEK293.

V.3 Esquema del fundamento del Pulso de Amonio $\left(\mathrm{NH}_{4}{ }^{+}\right)$.

V.4 Construcción de la curva de calibración de pH vs fluorescencia en células HEK293

V.5 Esquema de la despolarización con alto $\mathrm{K}^{+}$

V.6 Ensayo de coinmunoprecipitación

V.7 Ensayo de GST Pull down. 


\section{Lista de Tablas}

I.1 Resumen de las características de las 3 isoformas existentes para el NBC.

I.2 Porcentaje de identidad de la familia SLC4

II.1 Resumen de las isoformas existentes para la AC IX en el hombre

VI.1 Secuencias de los primers utilizados en la reacción de PCR 


\section{El cotransportador $\mathrm{Na}^{+} / \mathrm{HCO}_{3}{ }^{-}$cardíaco}

\section{I.1 Regulación del $\mathrm{pH}_{\mathrm{i}}$ cardíaco}

El músculocardíaco mantiene una actividad continua con un ritmo regular de contracción-relajación y un metabolismo estrictamente aeróbico [1]. Como resultado de este metabolismo, grandes cantidades de $\mathrm{CO}_{2}$ como producto de desecho son generados, los cuales al hidratarse incrementan la concentración de $\mathrm{H}^{+}$; por lo tanto, el $\mathrm{pH}$ intracelular $\left(\mathrm{pH}_{\mathrm{i}}\right)$ de los miocitos cardíacos tiende a disminuir. Todos los procesos bioquímicos y fisiológicos sólo ocurren en un rango óptimo de $\mathrm{pH}$. A valores menores al $\mathrm{pH}_{\mathrm{i}}$ fisiológico ( $\left.\simeq 7.2\right)$ se evidencian serios inconvenientes en el funcionamiento normal del miocito: disminución de la afinidad de las proteínas contráctiles por el calcio y por lo tanto disminución en la contractilidad [1, 2]; cambios en el manejo de $\mathrm{Ca}^{2+}$ intracelular [3] y, en ciertas condiciones, la disminución del $\mathrm{pH}_{\mathrm{i}}$ puede gatillar arritmias [4].

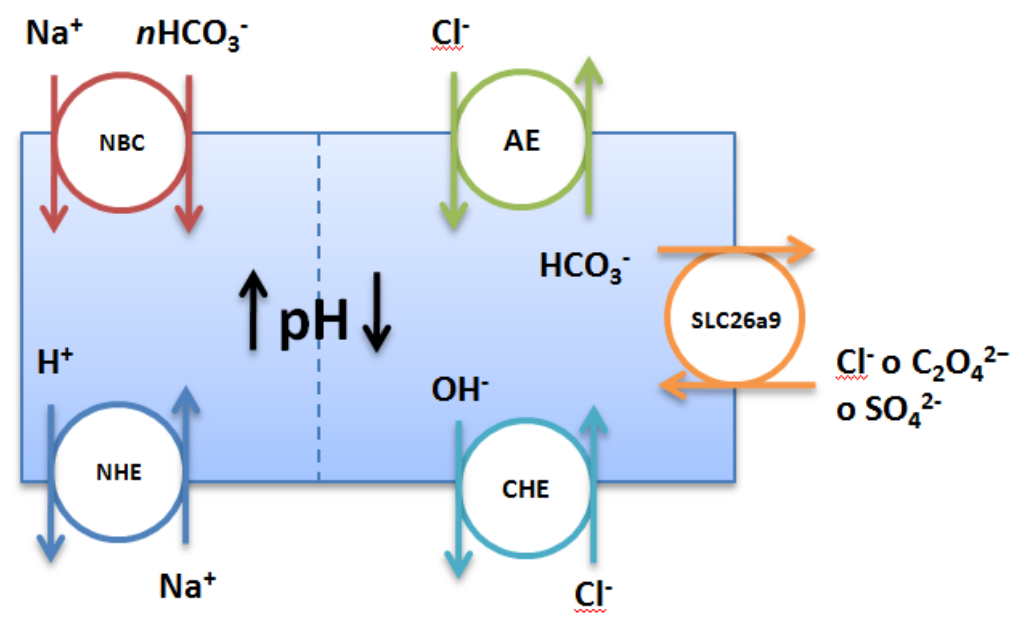

Figura I.1: Se esquematizan los cinco principales mecanismos reguladores del $\mathrm{pH}_{\mathrm{i}}$ en cardiomiocitos. Dos mecanismos alcalinizantes (NBC y NHE) aumentan el $\mathrm{pH}_{\mathrm{i}}$ cuando este disminuye por debajo del fisiológico, mientras que otros tres, los acidificantes (AE, CHE o SLC26a9), disminuyen el $\mathrm{pH}_{\mathrm{i}}$ cuando está por encima de lo normal. 
Por lo tanto, para el correcto funcionamiento tanto eléctrico como contráctil es necesaria una regulación estricta del $\mathrm{pH}_{\mathrm{i}}$ cardíaco [5].

Cada cardiomiocito posee diferentes transportadores iónicos de membrana encargados de la minuciosa tarea de regular el $\mathrm{pH}_{\mathrm{i}}$ (figura I.1). Existen dos mecanismos alcalinizantes: el intercambiador $\mathrm{Na}^{+} / \mathrm{H}^{+}$o NHE, que cataliza el influjo de un $\mathrm{Na}^{+}$por cada $\mathrm{H}^{+}$que extrae del espacio citosólico [6, 7], y el cotransportador $\mathrm{Na}^{+} / \mathrm{HCO}_{3}{ }^{-}$o NBC, que impulsa el coinflujo de un $\mathrm{Na}^{+}$por una o dos moléculas de $\mathrm{HCO}_{3}^{-}$[8]. Otros dos mecanismos disminuyen el $\mathrm{pH}_{\mathrm{i}}$, es decir acidifican, el intercambiador $\mathrm{Cl}^{-} / \mathrm{HCO}_{3}{ }^{-}$o $\mathrm{AE}$ y el $\mathrm{Cl}^{-} / \mathrm{OH}^{-}$o $\mathrm{CHE}$, ambos ingresan un $\mathrm{Cl}^{-}$por cada $\mathrm{HCO}_{3}{ }^{-} \mathrm{u} \mathrm{OH}^{-}$respectivamente [9-11]. Además, recientemente se ha demostrado en miocitos cardíacos de la posible existencia de un nuevo intercambiador aniónico acidificante denominado $\mathrm{SLC} 26 \mathrm{a} 6$ capaz de intercambiar $\mathrm{Cl}^{-} / \mathrm{HCO}_{3}{ }^{-}$, así como también sulfato $\left(\mathrm{SO}_{4}{ }^{2-}\right) \mathrm{u}$ oxalato $\left(\mathrm{C}_{2} \mathrm{O}_{4}{ }^{2-}\right)$ [9]. En la figura $\mathrm{I} .2$ se esquematiza la interrelación de los productos proteicos según la similitud de las secuencias aminoacídicas.

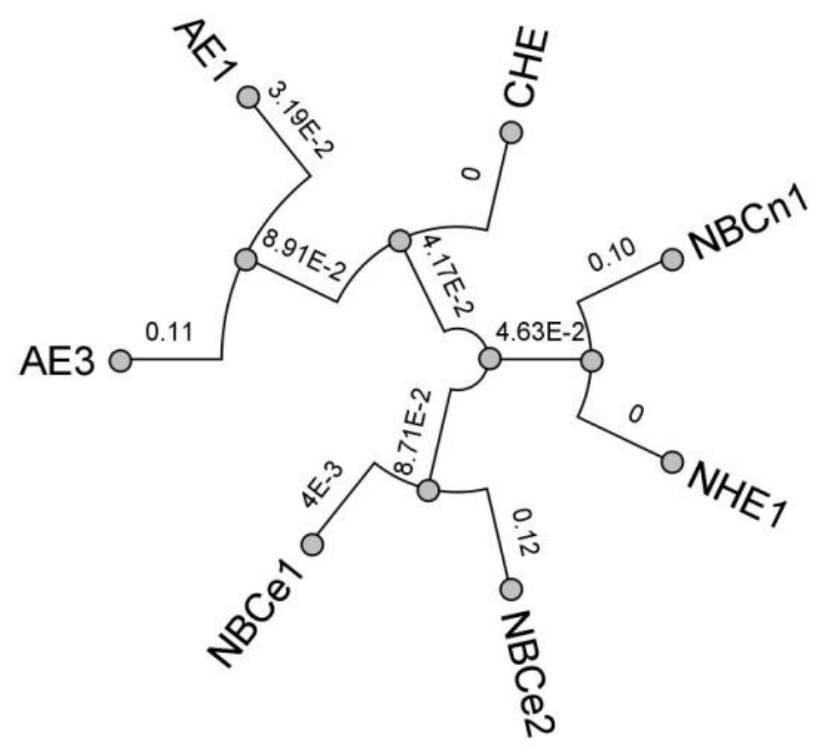

Figura I.2: Análisis filogenético de los mecanismos reguladores de $\mathrm{pH}_{\mathrm{i}}$ en cadiomiocitos. Se utilizó la secuencia de aminoácidos de una variante representativa de splicing para cada uno de los 7 genes y, para simplificar el concepto de la identidad de secuencias, se usó al humano como especie. (Geneious Pro 3.6.1). 
En condiciones de ausencia de $\mathrm{HCO}_{3}{ }^{-}$el único mecanismo alcalinizante es el NHE. En condiciones fisiológicas, en las cuales el $\mathrm{HCO}_{3}{ }^{-}$se encuentra presente, la contribución a pH cercanos al basal es prácticamente la misma para el NHE y el NBC. Esta diferencia se modifica a medida que el pH basal disminuye adquiriendo mayor importancia el NHE. [5]

\section{I.2 El Cotransportador $\mathrm{Na}^{+} / \mathrm{HCO}_{3}{ }^{-}$(NBC)}

NBCe1

En 1981, Boron y Boulpaep trabajando en túbulos renales de salamandra describieron un cotransporte electrogénico dependiente de $\mathrm{Na}^{+}$y de $\mathrm{HCO}_{3}^{-}$[12]. Años más tarde en 1997 Romero et al. clonaron por primera vez la secuencia encargada de codificar a la proteína bautizada aNBCe1-A. NBC por sus siglas en ingles $\mathrm{Na}^{+} /$Bicarbonate Cotransporter, "a" por Ambistoma (Salamandra), "e" por electrogénico, "A" por la primer variante de splicing del gen y "1" por ser el primero de dos genes que codifican para un cotransporte $\mathrm{Na}^{+} / \mathrm{HCO}_{3}{ }^{-}$ electrogénico [13]. Poco tiempo después, se halló la presencia de este contrasporte en otras especies como en la rata y en el humano $[14,15]$.

Actualmente se conocen otras dos variantes de splicing para el cotransporte NBCe1. NBCe1-B que ha sido clonado en páncreas [16] y en corazón $[13,17]$ y es la variante más común, mientras que la tercera, NBCe1-C, se encuentra exclusivamente en cerebro [18].

El NBCe1 posee al menos dos estequiometrías dependiendo del sistema en el cual se halla, 1:2 o 1:3 $\left(\mathrm{Na}^{+}: \mathrm{HCO}_{3}{ }^{-}\right)$. Investigaciones en ovocitos de Xenopus que expresaban heterólogamente la variante NBCe1-A revelaron una estequiometría 1:2 [19]. Muller-Berger et al. trabajando en el mismo modelo experimental encontraron que la estequiometría era 1:2 cuando la concentración de calcio en el lado citosólico era de 100nM o menos; en cambio, la estequiometría se modificaba a 1:3 cuando el calcio aumentaba a 500nM [20]. Gross y colaboradores descubrieron que tanto el NBCe1-A como NBCe1-B cuando son expresados en una línea celular de túbulos renales proximales poseen una estequiometría 1:3 [21]. Mientras 
que estudios realizados por nuestro laboratorio determinaron en miocitos aislados de gato y rata una estequiometría de 1:2 [22, 23]

\section{NBCe2}

En el año 2000 el grupo de Kurtz identificó en células cardíacas de humanos un segundo contransportador $\mathrm{Na}^{+} / \mathrm{HCO}_{3}{ }^{-}$electrogénico, al cual denominó NBCe2 [24]. Mientras que se ha descripto la presencia del NBCe2 en varios tejidos de ratón (hígado, testículos, riñón, corazón, páncreas, cerebro, estómago y pulmón), estudios recientes realizados por nuestro laboratorio sólo han podido identificar a la isoforma NBCe1 como la única isoforma responsable del cotransporte electrogénico de $\mathrm{Na}^{+} / \mathrm{HCO}_{3}{ }^{-}$, en miocitos ventriculares de rata. Esto significa que el rol funcional de NBCe2 en miocitos de gato y rata es cuestionado [25].

NBCn1

Otro cotransporte $\mathrm{Na}^{+} / \mathrm{HCO}_{3}{ }^{-}, \mathrm{NBC} 3$ fue clonado por primera vez en músculo esquelético de humano $[26,27]$. En el año 2000, tres variantes más del NBC3 fueron encontradas y caracterizadas electrofisiológicamente a partir de la aorta de rata determinándose que era un cotransporte electroneutro, con una estequiometria 1:1; por esta razón se lo rebautizó como NBCn1 $[28,29]$.

Mediante la técnica de Northern-blots se determinó la presencia del NBCn1 en rata, hallándose en varios tejidos como páncreas, testículos, cerebro, hígado, riñón e inclusive corazón [29]. Recientemente hemos demostrado una contribución equivalente para las isoformas NBCn1 y NBCe1 en la recuperación del $\mathrm{pH}_{\mathrm{i}}$ tras una acidosis en miocitos ventriculares de gato [25]. 


\begin{tabular}{|c|c|c|c|c|c|c|c|c|}
\hline Gen & Proteína & Alias & Sustratos & $\begin{array}{l}\text { Distribución } \\
\text { tisular/celular }\end{array}$ & Asociación patológica & $\begin{array}{l}\text { Locus } \\
\text { cromosómico }\end{array}$ & ID Secuencia & $\begin{array}{c}\text { variantes } \\
\text { de } \\
\text { Splicing }\end{array}$ \\
\hline SLC4a4 & NBCe1 & $\begin{array}{l}\text { NBC } \\
\text { NBC1 }\end{array}$ & $\begin{array}{c}\text { Sodio/ } \\
\text { Bicarbonato }\end{array}$ & $\begin{array}{l}\text { NBC1-A: Riñón, } \\
\text { túbulos proximales. } \\
\text { NBC-B: Páncreas, } \\
\text { Corazón, Retina. } \\
\text { NBC-C: Cerebro }\end{array}$ & $\begin{array}{l}\text { Anormalidades } \\
\text { oculares y acidosis } \\
\text { tubular severa. } \\
\text { Problemas de } \\
\text { crecimiento. } \\
\text { Migrañas. }\end{array}$ & $4 q 21$ & NM_003759 & 3 \\
\hline SLC4a5 & NBCe2 & NBC4 & $\begin{array}{c}\text { Sodio/ } \\
\text { Bicarbonato }\end{array}$ & $\begin{array}{c}\text { Hígado, testículos, } \\
\text { Bazo. }\end{array}$ & 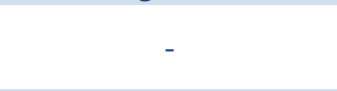 & $2 p 13$ & NM_133478 & 1 \\
\hline SLC4a7 & NBCn1 & $\begin{array}{l}\text { NBC2 } \\
\text { NBC3 }\end{array}$ & $\begin{array}{c}\text { Sodio/ } \\
\text { Bicarbonato }\end{array}$ & $\begin{array}{l}\text { Bazo, testículos, } \\
\text { cerebro, corazón, } \\
\text { pulmón, hígado, } \\
\text { riñón y músculo } \\
\text { esquelético. }\end{array}$ & $\begin{array}{l}\text { Deterioro auditivo y } \\
\text { Ceguera en ratón. }\end{array}$ & $3 p 22$ & NM_003615 & 3 \\
\hline
\end{tabular}

Tabla I.1: Resumen de las características de las 3 isoformas existentes para el NBC.

\section{I.3 Estructura}

El cotransportador NBCe1 es una glicoproteína de membrana de 1035 aminoácidos y su peso molecular aproximado es de $130 \mathrm{kDa}$. Estudios topológicos de glicosilación realizados por el grupo de Kurtz en Los Ángeles, demostraron que las cadenas peptídicas atraviesan al menos en 10 oportunidades la bicapa lipídica [28]. Basándose en la estructura topológica del intercambiador aniónico 1 (AE1) y gráficos de hidropatía se predicen 13 dominios transmembranas (DT) y 2 bucles reentrantes [30, 31] (figura I.3). Además, entre los dominios transmembranas 5 y 6 existe un largo bucle extracelular glicosilado (Loop 3), y uno más pequeño entre los dominios 7 y 8 (Loop 4), a los que se la han atribuido propiedades regulatorias [32]. 


\begin{tabular}{ccccccc}
\hline & AE1 & AE2 & AE3 & NBCe1 & NBCe2 & NBCn1 \\
\hline AE1 & $100 \%$ & $55 \%$ & $53 \%$ & $34 \%$ & $29 \%$ & $33 \%$ \\
AE2 & & $100 \%$ & $56 \%$ & $34 \%$ & $28 \%$ & $30 \%$ \\
AE3 & & & $100 \%$ & $34 \%$ & $30 \%$ & $31 \%$ \\
NBCe1 & & & & $100 \%$ & $53 \%$ & $50 \%$ \\
NBCe2 & & & & & $100 \%$ & $39 \%$ \\
NBCn1 & & & & & & $100 \%$ \\
\hline
\end{tabular}

Tabla I.2: Porcentaje de identidad de la familia SLC4. El porcentaje de identidad se realizó con la secuencia de aminoácidos de una variante representativa de splicing para cada transportador, utilizando el programa Geneious Pro 3.6.1.

Sin la ayuda de estructuras cristalinas, la disposición espacial de los aminoácidos del NBC aún no está del todo definida. Sin embargo, por ensayos como mutagénesis por escaneo de cisteínas, se han involucrado varios residuos aminoacídicos en la formación del poro de translocación de los iones, los cuales están sobre el DT 8, muy cercano al Loop 4 [33].

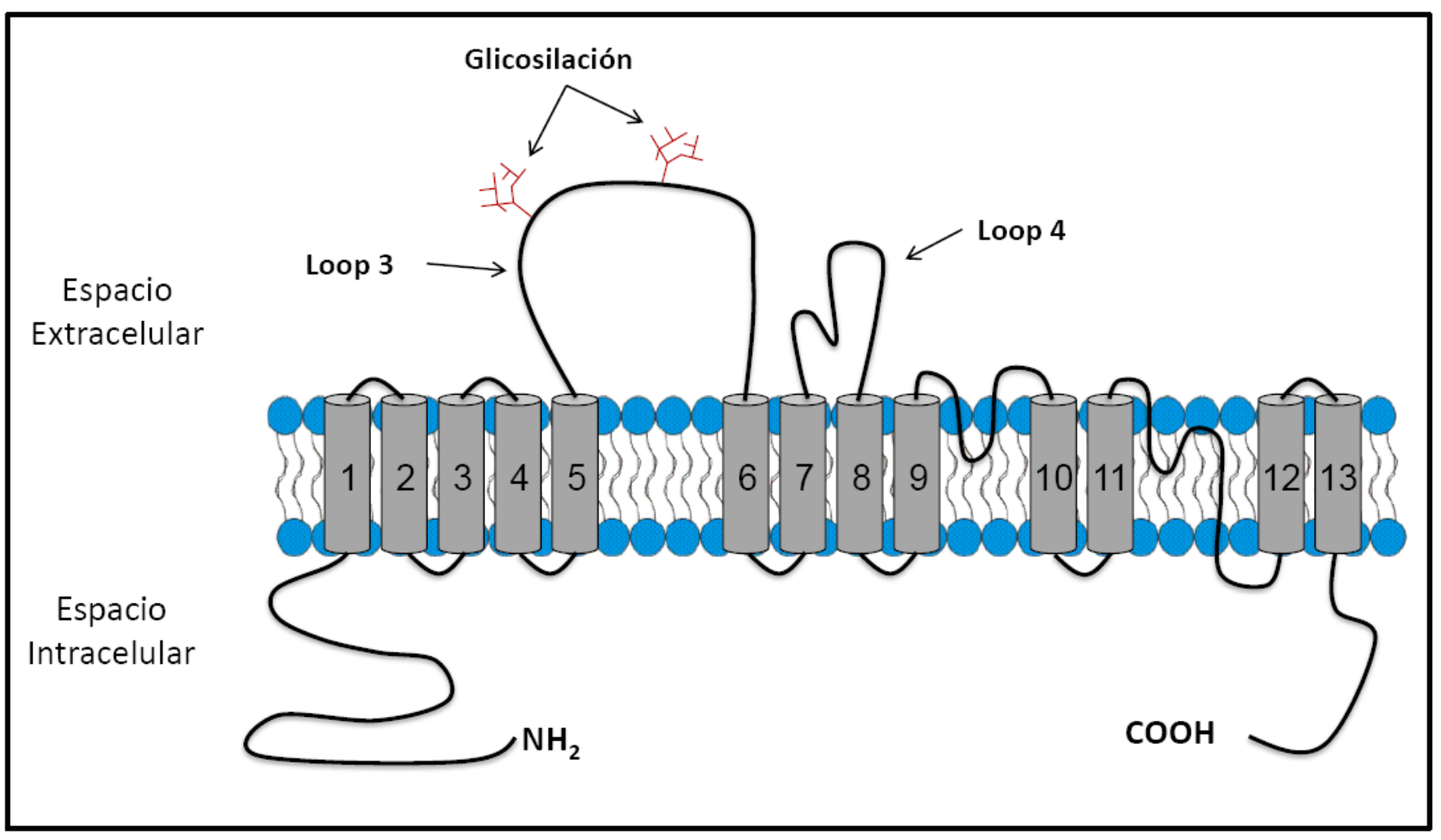

Figura 1.3: Modelo topológico del NBCe1. Se distinguen los dominios N-terminal y C-terminal intracelulares y los bucles extracelulares 3 y 4 (Loop 3 y Loop4). Se propone que los sitios de glicosilación se encuentran sobre el Loop3. 


\section{I.4 Regulación}

Debido a la importancia del cotransporte $\mathrm{Na}^{+} / \mathrm{HCO}_{3}{ }^{-}$en los túbulos renales, la mayor parte de la bibliografía especializada en estudiar su regulación es en riñón. Sin embargo, recientemente hemos demostrado en miocitos aislados de gato que la hormona angiotensina II (Ang II) posee efectos opuestos dependiendo sobre qué isoforma del NBC actúe (figura I.4), donde a través de receptores AT1 ejerce una regulación inhibitoria sobre el NBCe1 y estimulatoria sobre el NBCn1 [34, 35].

Además, Kohout et al. demostraron la activación del NBC en miocitos ventriculares de ratas neonatas a través de receptores AT2 y un mecanismo fosfoinositolindependiente [36]. Sin embargo, recientemente se describió la activación por fosfatidilinositol 4,5-bisfosfato (PIP2) del NBCe1 expresado en ovocitos de Xenopus [37].

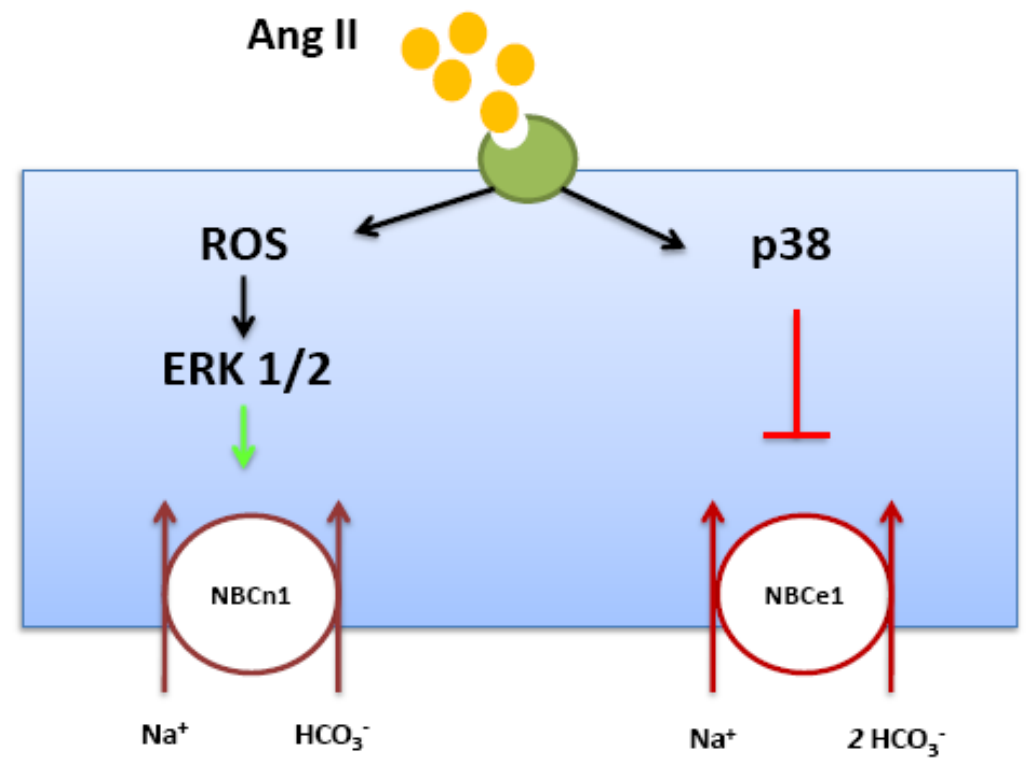

Figura I.4: Resumen del efecto dual de la Angiontesina II sobre cada una de las dos isoformas presentes en el cardiomiocito. La Ang II a través de sus receptores AT1 provoca la activación de dos vías intracelulares diferentes. Por un lado, la activación de la quinasa p38, por un mecanismo desconocido, produce la inhibición del NBCe1. Mientras que la activación de la quinasa ERK1/2 a través de las especies reactivas de oxigena (ROS) incrementa la actividad mediada por NBCn1. 
La regulación por el sistema nervioso autónomo también es conocida, los agonistas $\beta$ adrenérgicos provocan la activación del NBC mientras que los agonistas $\alpha$-adrenérgicos provocan su inhibición [38].

Otro mecanismo regulatorio del NBC es a través de su fosforilación directa. Gross et al. trabajando en una línea celular de túbulos proximales de riñón (MPCT) demostraron que el 8Br-cAMP provoca un cambio de la estequiometria del NBCe1 de 1:3 a 1:2 por la fosforilación de la Ser ${ }^{982}$ mediada por la proteína quinasa A (PKA). La variante NBCe1-B, la cual se encuentra en el páncreas y corazón, posee además otro sitio consenso para PKA en el extremo amino terminal $\left(\mathrm{KRKT}^{49}\right)$, cuya fosforilación aumenta la conductancia del cotransportador [39].

\section{I.5 Fisiología y fisiopatología del NBC cardíaco}

La principal función del NBC cardíaco, como ya se indicó, es regular el $\mathrm{pH}_{\mathrm{i}}$, contribuyendo en un $50 \%$ a la extrusión de protones [40]. A su vez, la corriente repolarizante generada por el NBCe1, descripta por primera vez en nuestro laboratorio, contribuye a la duración y a la configuración del potencial de acción en miocitos aislados de gato y rata [22, 23].

Conjuntamente con el influjo de $\mathrm{HCO}_{3}{ }^{-}$, ingresa a la célula $\mathrm{Na}^{+}$, contribuyendo en un $30 \%$ del total de $\mathrm{Na}^{+}{ }_{i}$ a $\mathrm{pH}_{\mathrm{i}}: 6.8$ [41]. Es conocido que el incremento en la $\mathrm{Na}^{+}{ }_{\mathrm{i}}$ puede inducir un aumento en los niveles intracelulares de $\mathrm{Ca}^{2+}$ a través del intercambiador $\mathrm{Na}^{+} / \mathrm{Ca}^{2+}(\mathrm{NCX})$ ya sea como resultado de una descenso del eflujo de $\mathrm{Ca}^{2+}$ (disminución del modo directo) o un incremento de la entrada $\mathrm{Ca}^{2+}$ (aumento del modo inverso) generando una sobrecarga perjudicial de $\mathrm{Ca}^{2+}{ }_{i}$ [42-44]. El incremento en la concentración de $\mathrm{Na}^{+}{ }_{\mathrm{i}}$ desplaza el potencial de inversión del $\mathrm{NCX}\left(\mathrm{E}_{\mathrm{NCX}}\right)$ hacia valores más negativos, otorgando más tiempo para que el $\mathrm{NCX}$ actúe en su modo inverso durante el potencial de acción y promueva el influjo de $\mathrm{Ca}^{2+}$ a la célula. El incremento en la concentración de $\mathrm{Ca}^{2+}{ }_{\mathrm{i}}$ actúa como una señal hipertrófica, ya sea a través de la calcineurina o de la quinasa regulada por $\mathrm{Ca}^{2+}$ y calmodulina (CaMKII) $[45,46]$. 
Además, este incremento de $\mathrm{Ca}^{2+}{ }_{i}$ es retomado por el retículo sarcoplásmico a través de la bomba $\mathrm{Ca}^{2+}$-ATPasa (SERCA). Cuando se produce una sobrecarga intracelular de $\mathrm{Ca}^{2+}$, el retículo sarcoplásmico genera liberaciones espontáneas de $\mathrm{Ca}^{2+}$ que no han sido gatilladas por la despolarización del sarcolema. Esta liberación de $\mathrm{Ca}^{2+}$, si se produce en el momento oportuno del ciclo cardíaco, es decir, cuando la repolarización se ha completado durante la diástole ventricular, conduce a la generación de arritmias ventriculares por actividad gatillada, conocidas como post-despolarizaciones tardías ("delay after depolarizations", DADs), debido a la aparición de una corriente despolarizante transitoria $\left(I_{\mathrm{ti}}\right)$ por la actividad del NCX en su modo directo (figura I.5).

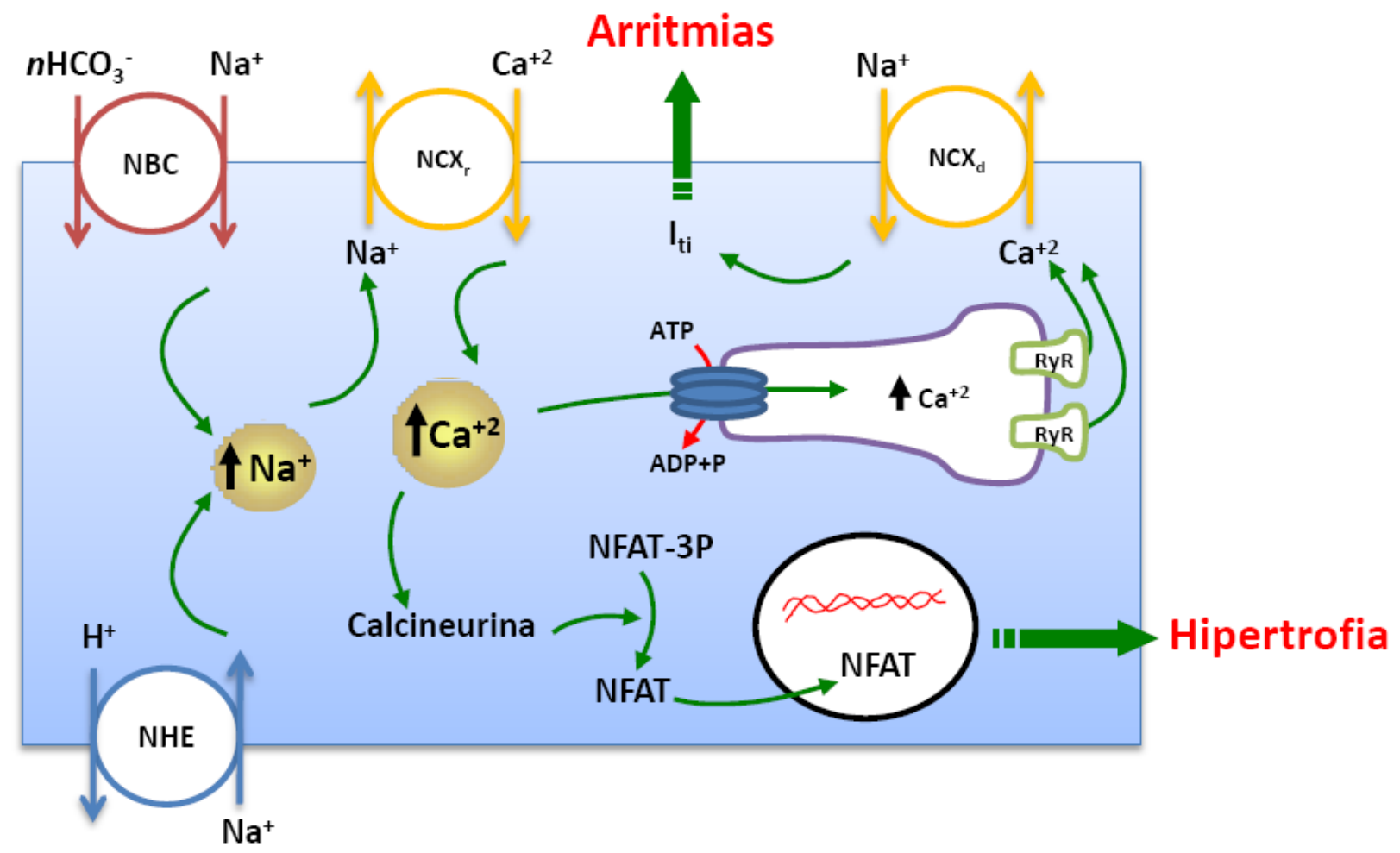

Figura I.5: Esquema del posible efecto deletéreo del NBC. Al igual que el NHE, el NBC utiliza un transporte dependiente de $\mathrm{Na}^{+}$, el cual ingresa al interior celular provocando un aumento de su concentración. Al aumentar la concentración de $\mathrm{Na}^{+}$provoca que la fuerza impulsora del NCX disminuya, reduciendo la salida del $\mathrm{Ca}^{2+}$. Inclusive si la concentración de $\mathrm{Na}^{+}$aumenta significativamente puede revertir la dirección del $\mathrm{NCX}$, transportando $\mathrm{Ca}^{2+}$ al interior y sacando $\mathrm{Na}^{+}$. Esto resulta en un aumento del $\mathrm{Ca}^{2+}$ citosólico el cual es el precursor de señales hipertróficas y de arritmias. 
La inhibición del intercambiador $\mathrm{Na}^{+} / \mathrm{H}^{+}$(NHE) evita y revierte la hipertrofia y las arritmias inducidas por el mecanismo anteriormente descripto [47]. Esto motivó la realización de un ensayo clínico. Desafortunadamente, los efectos beneficiosos del bloqueante farmacológico del NHE, el cariporide (HOE642), fueron opacados por una elevada incidencia de accidentes cerebrovascualres (ACV) con lo que el ensayo clínico fue interrumpido [48]. Se ha propuesto que al igual que el NHE, la inhibición del NBC, podría ser un mecanismo alternativo para el tratamiento de enfermedades cardiovasculares [43].

Yamamoto et al. encontraron una sobrexpresión del ARNm de NBCe1 y NBCn1 en ratas hipertróficas por sobrecarga de presión inducidas por coartación aórtica [49]. Adicionalmente, se ha sugerido la implicancia del NBC en experimentos de isquemia/reperfusión, en los cuales la inhibición del NBC reduce el daño generado por la isquemia [50].

Existen diferencias en el manejo del $\mathrm{Na}^{+}{ }_{i}$ y el $\mathrm{Ca}^{2+}{ }_{i}$ entre las dos isoformas del cotransportador $\mathrm{Na}^{+} / \mathrm{HCO}_{3}{ }^{-}$presentes en el miocito (NBCe1 y NBCn1).

Con respecto al $\mathrm{Na}^{+}{ }_{i}$, gracias a su estequiometria, el NBCe1 contribuye con $1 / 2 \mathrm{Na}^{+}$por $\mathrm{HCO}_{3}{ }^{-}$que ingresa, siendo más eficiente en el momento de regular el $\mathrm{pH}_{\mathrm{i}}$ con respecto al ingreso de $\mathrm{Na}^{+}$, a diferencia del NBCn1 en donde la relación es 1:1.

El bloqueo de NBCe1 produce un alargamiento del potencial de acción al inhibir la corriente repolarizante que genera, por lo tanto, esta inhibición podría provocar un aumento del $\mathrm{Ca}^{2+}{ }_{\mathrm{i}}$ al alargar la meseta y de esta forma aumentar el influjo de calcio.

Si bien existen investigaciones en los que se implica al NBC con la fisiopatología cardiovascular no existe hasta el momento evidencias concretas de causalidad. 


\section{Regulación física del cotransportador NBCe1 por la anhidrasa carbónica IX}

\section{II.1 Introducción}

Las anhidrasas carbónicas $(A C)$ son una familia de metaloenzimas que se encuentran prácticamente en todos los organismos, desde los más primitivos, como las cianobacterias, hasta los mamíferos superiores [51]. En su centro catalítico posee un ion zinc $\left(\mathrm{Zn}^{2+}\right)$ que se encuentra coordinado por los anillos imidazol de tres histidinas. Dicha región, es fundamental en la hidratación reversible del dióxido de carbono $\left(\mathrm{CO}_{2}\right)$ para producir un intermediario inestable, el ácido carbónico $\left(\mathrm{H}_{2} \mathrm{CO}_{3}\right)$, que rápida y espontáneamente se hidroliza en $\mathrm{HCO}_{3}{ }^{-}$y $\mathrm{H}^{+}$ [52].

$\mathrm{CO}_{2}+\mathrm{H}_{2} \mathrm{O} \rightleftharpoons\left[\mathrm{H}_{2} \mathrm{CO}_{3}\right] \rightleftharpoons \mathrm{HCO}_{3}{ }^{-}+\mathrm{H}^{+}$

La tasa de reacción de las ACs es de las más rápidas que se conocen en la naturaleza. Según las diferentes isoformas, pueden alcanzar valores entre $10^{7}$ y $10^{9}$ reacciones por segundo, limitadas típicamente por la tasa de difusión y la concentración del sustrato [53].

La reacción limitante es la hidratación/deshidratación del $\mathrm{CO}_{2}$. Ésta posee una constante de reacción de 0.017 a $25{ }^{\circ} \mathrm{C}$ y 1 atm, siendo espontánea y en dirección a su hidratación cuando se encuentra en el equilibrio. Fisiológicamente las concentraciones de $\mathrm{CO}_{2} \mathrm{y} \mathrm{HCO}_{3}{ }^{-}$dependerán 
del tejido e inclusive del microdominio celular, siendo muy diferentes a las concentraciones en el equilibrio. Por lo tanto, la dirección de la reacción estará determinada por las diferentes concentraciones de reactivos y productos.

Actualmente se han descripto al menos 16 miembros de la familia de las AC que se diferencian entre sí en su actividad, distribución tisular y localización subcelular [54].

Las células cardíacas expresan al menos 5 isoformas: una de localización mitocondrial, AC VB y ACVA [55]; una citosólica, AC II [56]; y otras 3 cuyos dominios catalíticos se encuentran en la región extracelular. Éstas se asocian a la membrana plasmática por dominios transmembranas como la AC IX, la ACXII y la AC XIV, o ancladas por un grupo glicosilfosfatidilinositol como la AC IV [57].

\begin{tabular}{|c|c|c|c|c|}
\hline Isoforma & Gen & $\begin{array}{c}\text { Peso } \\
\text { molecular }\end{array}$ & $\begin{array}{l}\text { Localización } \\
\text { celular }\end{array}$ & Localización tisular \\
\hline$A C I$ & AC1|1368 & $29 \mathrm{kDa}$ & Citoplasma & $\begin{array}{l}\text { Glóbulos rojos y tracto } \\
\text { gastrointestinal }\end{array}$ \\
\hline$A C \|$ & AC2|1373 & 29 kDa & Citoplasma & $\begin{array}{l}\text { Ampliamente distribuida, } \\
\text { inclusive en corazón }\end{array}$ \\
\hline AC III & AC3|1374 & $29 \mathrm{kDa}$ & Citoplasma & Músculo esquelético \\
\hline AC IV & AC4|1375 & $35 \mathrm{kDa}$ & $\begin{array}{c}\text { Extracelularmente } \\
\text { unida a GPI }\end{array}$ & $\begin{array}{l}\text { Ampliamente distribuida, } \\
\text { inclusive corazón }\end{array}$ \\
\hline AC VA & AC5A & - & Mitocondria & $\begin{array}{l}\text { Hígado, riñón y músculo } \\
\text { esquelético, cerebro }\end{array}$ \\
\hline AC VB & AC5B & - & Mitocondria & Corazon, otros tejidos \\
\hline$A C$ VI & AC6|1380 & - & - & - \\
\hline AC VII & AC7|1381 & - & Citoplasma & - \\
\hline AC IX & AC9|1383 & $49,7 \mathrm{kDa}$ & $\begin{array}{c}\text { Asociada a } \\
\text { membrana celular }\end{array}$ & Corazón, Aparato digestivo. \\
\hline AC XII & $\mathrm{AC} 12 \mid 1371$ & $44 \mathrm{kDa}$ & $\begin{array}{l}\text { Sitio activo } \\
\text { localizado } \\
\text { extracelularmente }\end{array}$ & $\begin{array}{l}\text { Plexo coroide (cerebro) } \\
\text { Ciertos cánceres }\end{array}$ \\
\hline AC XIII & AC13|14914 & - & Citoplasma & - \\
\hline AC XIV & AC14|1372 & 54 kDa & $\begin{array}{c}\text { sitio activo } \\
\text { localizado } \\
\text { extracelularmente }\end{array}$ & $\begin{array}{l}\text { riñón, corazón, músculo } \\
\text { estriado, cerebro }\end{array}$ \\
\hline
\end{tabular}

Tabla II.1: Resumen de las isoformas existentes para la AC en el hombre. 


\section{II.2 Anhidrasa Carbónica IX}

En el año 1994 el gen de la anhidrasa carbónica IX fue clonado y caracterizado por primera vez por Pastorek et al. [58]. Los autores propusieron que la AC IX es una proteína que posee un dominio proteoglicano $\mathrm{N}$-terminal, un sitio catalítico que se encuentra orientado hacia el espacio extracelular [59], un dominio transmembrana y una porción intracitoplasmática la cual se la ha sugerido como un importante dominio de regulación de la AC IX por fosforilación $[60,61]$. Su estructura cristalina indica que se encuentra formando dímeros a través de un puente disulfuro entre las Cys-41 de cada monómero (figura II.1) [62].

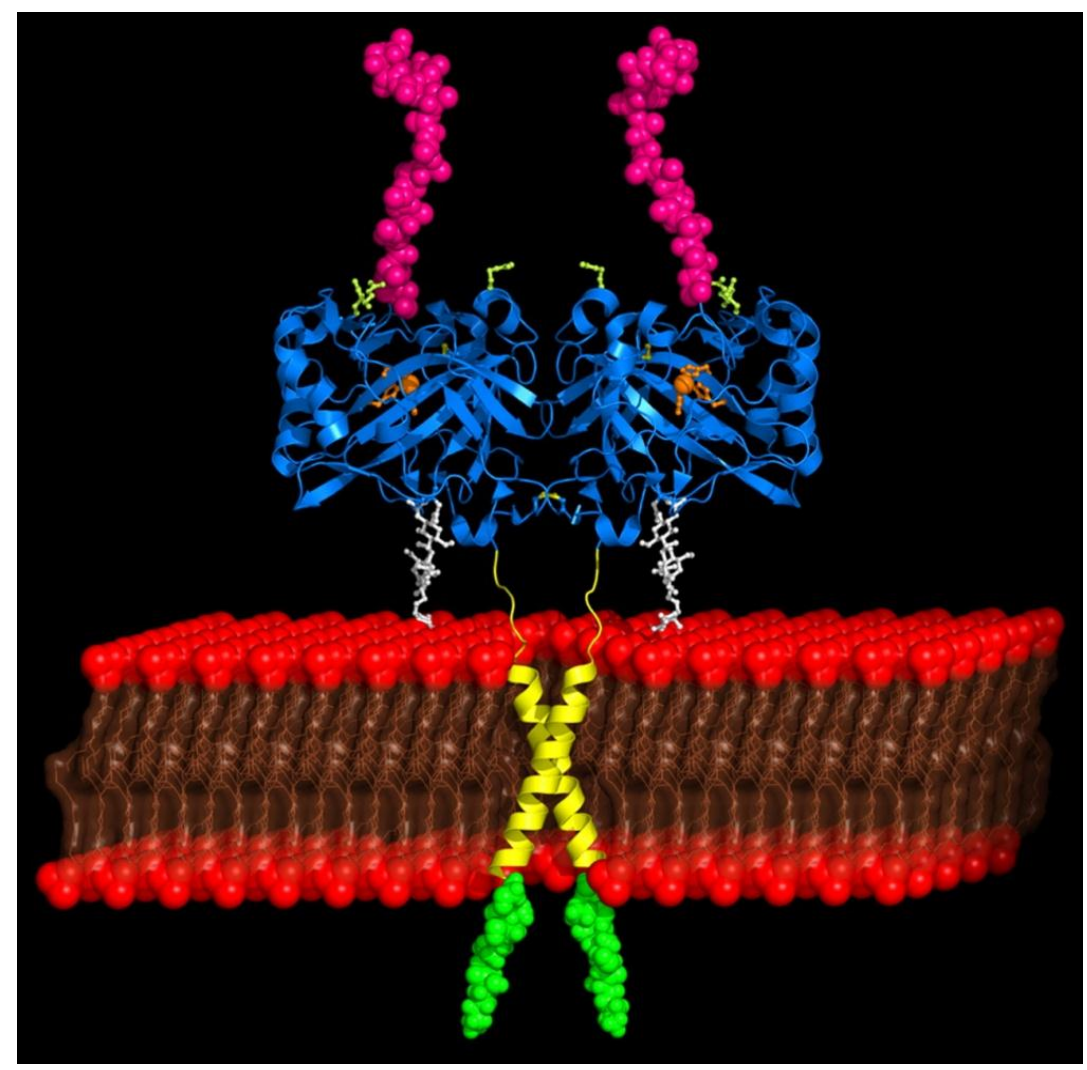

Figura II.1: Estructura tridimensional de la AC IX en la membrana celular. La estructura cristalina por difracción de rayos $\mathrm{X}$ muestra que el dominio catalítico de la AC IX (Azul) se encuentra en forma de dímeros. Además, se muestra esquemáticamente el dominio proteoglicano, la hélice transmembrana y la porción citoplasmática en magenta, amarillo y verde respectivamente. 
La isoforma IX de la anhidrasa carbónica es una enzima regulada por el factor inducible por hipoxia o HIF-1. La activación del HIF-1 por la caída de los niveles de $\mathrm{O}_{2}$ en la célula provoca su activación lo que desencadena la expresión de un conjunto de genes con el fin de adaptar a la célula a una condición de bajo $\mathrm{O}_{2}$. La sobreexpresión de la AC IX por la hipoxia ha sido muy estudiada en los tumores sólidos, donde la regulación del $\mathrm{pH}_{\mathrm{i}}$ es fundamental para el crecimiento y supervivencia de las células cancerígenas y además, la generación del ácido en el espacio extracelular aumenta la invasividad del tumor hacia tejidos adyacentes. Por estos motivos en los últimos años la AC IX ha sido utilizada como un marcador de hipoxia y de pronóstico de la progresión tumoral $[63,64]$.

Recientemente, se ha sugerido la sobreexpresión de AC IX por situaciones patológicas asociadas con la isquemia u otros disturbios metabólicos en miocitos cardíacos de rata [65]. Adicionalmente, Alvarez et al. han mostrado que la inhibición de las ACs pueden prevenir e inclusive revertir la hipertrofia en miocitos de ratón adulto y células neonatales de miocitos de rata [56]. Si bien atribuyen dicho fenómeno a la menor actividad del NHE (del cual se conoce su regulación funcional por AC II) [66], no se puede descartar la participación de los cotransportadores $\mathrm{Na}^{+} / \mathrm{HCO}_{3}{ }^{+}$. 


\section{II.3 Metabolón de transporte lónico}

El concepto de metabolón es utilizado cuando existe una interacción física entre dos enzimas que son parte de la misma vía, es decir el producto generado por la primera enzima es el reactivo de la segunda [67]. Como resultado de esta asociación espacial aumenta localmente la concentración de sustrato cercano al centro catalítico y por lo tanto su actividad enzimática.

La fuerza impulsora de un transportador iónico dependerá únicamente del gradiente de concentración del ión, y en el caso de los transportadores electrogénicos de su gradiente electroquímico. Cuando el metabolón se encuentra formado por enzimas que interaccionan con transportadores iónicos, estas aumentan localmente la concentración de iones producto de la actividad enzimática, favoreciendo el gradiente y por lo tanto el flujo que atraviesa la membrana a través del transportador. Además, puede ocurrir que el transporte sea favorecido no por el aumento de la concentración local del ión a transportar sino por la disipación del ión transportado (figura II.2).

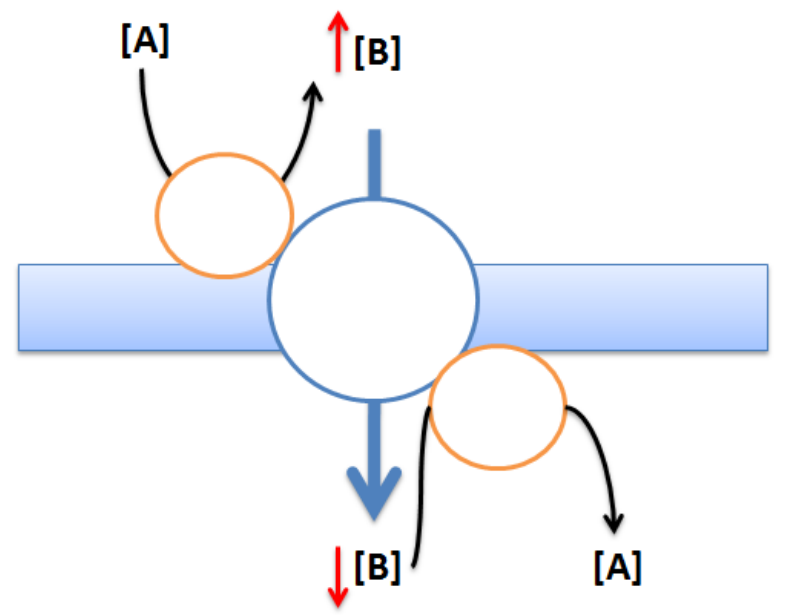

Figura II.2: Mecanismo de acción del metabolón de transporte iónico. Una enzima ubicada en el espacio extracelular cataliza la conversión de $A \rightarrow B$, aumentando su concentración muy cercanamente al transportador específico para B. Una vez en el interior, la enzima utiliza como sustrato a B para dar nuevamente A, disminuyendo la concentración de $\mathrm{B}$ y de esta forma aumenta la fuerza impulsora del transportador.

Se ha descripto que diversas $A C$ interaccionan física y funcionalmente con transportadores de membrana. En 1998, Vince et al. demostraron por primera vez en eritrocitos que la $A C$ II se encontraba unida a la región carboxilo terminal del intercambiador 
aniónico 1 (AE1) [68,69], siendo responsable del 40\% al 60\% de la actividad máxima [70]. Algo parecido ocurre con la AC IV, cuyo dominio catalítico se encuentra en la región extracelular. Al igual que para el AE1 se ha evidenciado que tanto el NBCe1 como el NBCn1 interacciona física y funcionalmente con la AC II y AC IV en la membrana basolateral de los túbulos renales [71] y en sistemas de expresión heterólogos [72]. Además, estudios recientes demostraron que las AC I, II y III forman un complejo funcional con NBCe1 cuando son coexpresadas en ovocitos de Xenopus [73].

La AC IX posee un patrón de expresión definido confinado a la región de los túbulos-t del músculo cardíaco [57] y esquelético [74]. Recientemente hemos localizado en miocitos aislados la expresión del NBCe1 en la membrana sarcolemal y en los túbulos-t [25]. El mismo patrón de localización subcelular sugiere que el NBCe1 y la AC IX podrían estar estructural y funcionalmente asociados.

Sin embargo, la interacción entre el NBCe1 y las AC en el tejido cardíaco hasta el momento no han sido estudiadas. Por este motivo, la primer parte de este trabajo estará centrado en la posible interacción física y cómo este acoplamiento estructural regula la funcionalidad del contransporte catalizado por NBCe1. 


\section{II.4 Objetivo General 1}

El objetivo de la primer parte del presente trabajo de tesis doctoral fue estudiar y caracterizar la formación de un complejo físico-funcional entre el cotransporte sodio/bicarbonato electrogénico $\mathrm{Na}^{+} / \mathrm{HCO}_{3}{ }^{-}$(NBCe1) y la ACIX.

Objetivos específicos

- Estudiar la interacción física del cotransportador NBCe1 y la AC IX, en miocitos cardíacos de ratas adultas y en células HEK293, a través de experimentos de coinmunoprecipitaciones y microscopía confocal.

- Describir la región a la cual la AC IX se asocia físicamente con el cotransportador NBCe1, realizando ensayos de GST-pull down.

- Demostrar que la interacción física entre ambas proteínas posee un correlato funcional utilizando miocitos aislados de rata o HEK293 transfectadas, midiendo el pH intracelular por epifluorescencia. 


\section{Resultados}

\section{II.5 Evidencia experimental de la interacción física de la anhidrasa carbónica IX y el cotransportador electrogénico NBCe1.}

El objetivo inicial de la primer parte de este trabajo fue estudiar la existencia de un acoplamiento físico entre el cotransporte electrogénico NBCe1 y las ACs. Para ello, se utilizaron lisados de corazón de rata para la realización de coinmunoprecipitaciones mediante anticuerpos específicos. NBCe1 fue inmunoprecipitado cuando se utilizó anticuerpos contra AC II y AC IV, revelando una interacción física entre el NBCe1 y la AC citosólica (AC II) y la asociada a glicosilfosfatidilinositol (AC IV). Interesantemente, NBCe1 también fue inmunoprecipitado cuando se utilizó el anticuerpo contra AC IX (figura II.3.A).

Adicionalmente, para demostrar la especificidad del experimento, se realizaron las inmunoprecipitaciones pero en ausencia de anticuerpo o en presencia de un anticuerpo irrelevante ( $\alpha$ GFAP, proteína gliofibrilar ácida). En estos experimentos no se encontraron bandas correspondientes al peso molecular del NBCe1.

En las figuras II.3.B y II.3.C podemos observar los inmunoblots correspondientes a lisados de corazones de rata, HEK293 transfectadas con NBCe1, AC IX o el vector vacío, revelando bandas inmunoreactivas de aproximadamente 130 y $50 \mathrm{kDa}$, correspondientes a NBCe1 y AC IX.

Estos resultados indican que el NBCe1 y las ACs presentes en diferentes compartimentos celulares interactúan en el músculo cardíaco. 


\section{A}

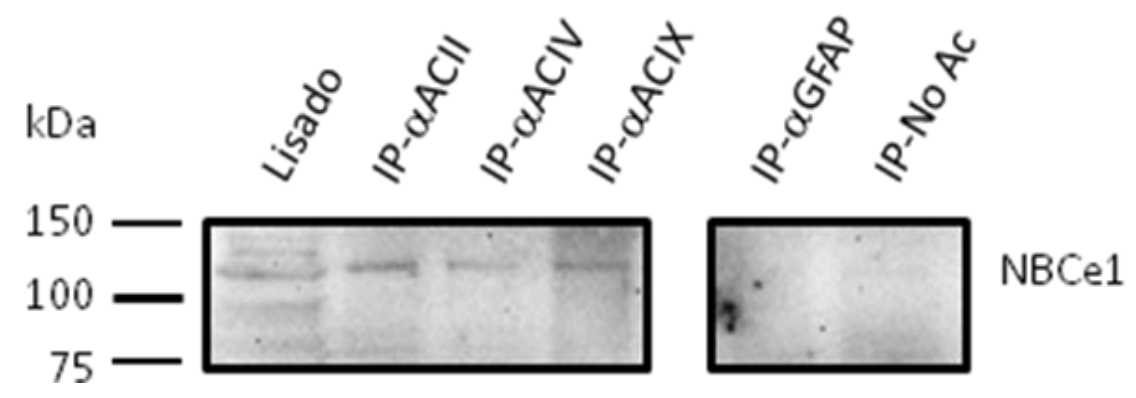

B

C
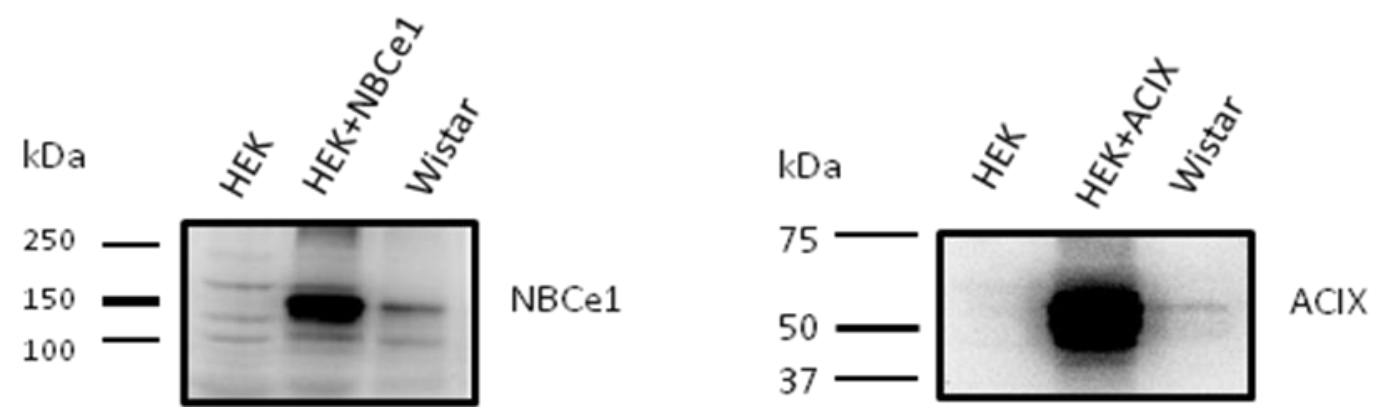

Figura II.3: Coinmunoprecipitaciones de las AC II, IV y IX y el NBCe1 en el corazón de rata. A. Lisados de ventrículos de rata fueron utilizados para realizar inmunoprecipitaciones con anticuerpos específicos dirigidos contra AC II, AC IV, AC IX, GFAP (irrelevante) o sin anticuerpo (No Ac). Las muestras fueron resueltas en un gel de poliacrilamida al $8 \%$ con SDS (SDS-PAGE) y se utilizó un anticuerpo específico contra NBCe1 para revelar su presencia. B y C. Inmunoblots de lisados de ventrículos de rata, HEK293 transfectadas con NBCe1 o AC IX y HEK293 sin transfectar, incubados con un anticuerpo contra NBCe1 (B) o contra AC IX (C).

Se utilizó un sistema heterólogo como el que proporciona la línea celular HEK293 para estudiar la interacción física en forma aislada. Este tipo de células fueron generadas por la transformación de células embrionarias de riñón humano, las cuales sólo expresan la AC II.

Mediante la técnica del fosfato de calcio se transfectaron con plásmidos que poseen los genes codificantes para las proteínas de interés. Luego se prosiguió con la técnica de coinmunoprecipitación (ver materiales y métodos). En la figura II.4.A se observan los resultados evidenciados mediante Western-blots. Como podemos ver, existe interacción física entre NBCe1 y AC IX ya que al precipitar con un anticuerpo específico de AC IX (IP- $\alpha A C$ IX) 
concomitantemente precipita NBCe1, pero no ocurre cuando las células sólo se encuentran transfectadas con NBCe1 o sólo con AC IX o no se utiliza un anticuerpo para inmunoprecipitar, lo que demuestra la especificidad del ensayo. En las figuras II.4.B y II.4.C se muestran que efectivamente las células se encontraban transfectadas y expresaban las proteínas correspondientes.

Estos experimentos demuestran que el NBCe1 y la AC IX forman un complejo estable cuando son coexpresados en un sistema heterólogo como las células HEK293.

A

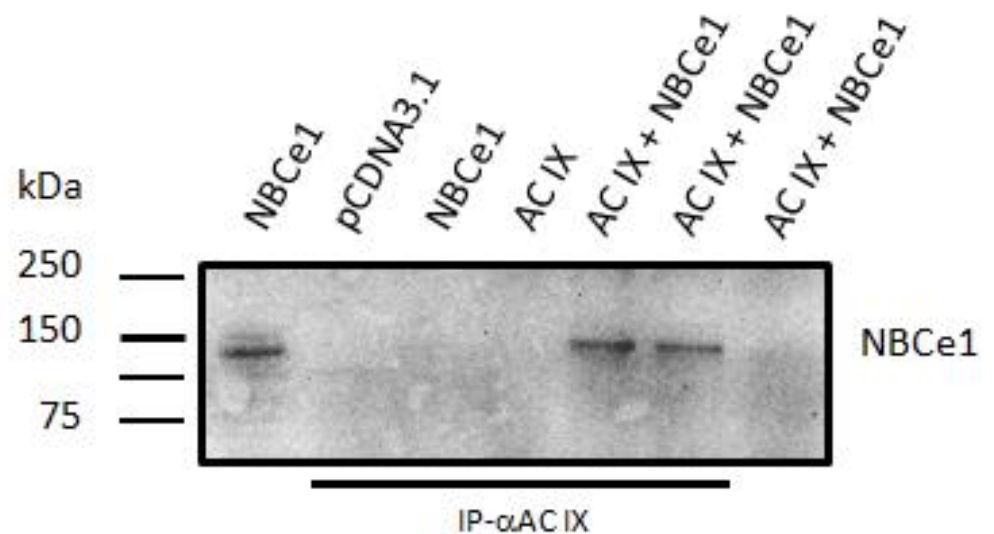

B

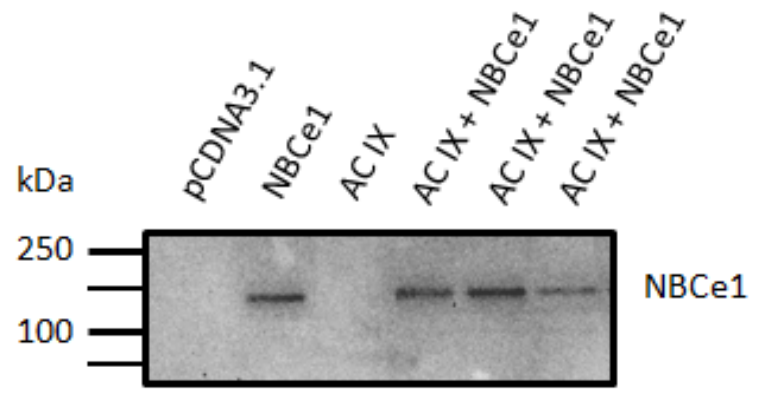

C

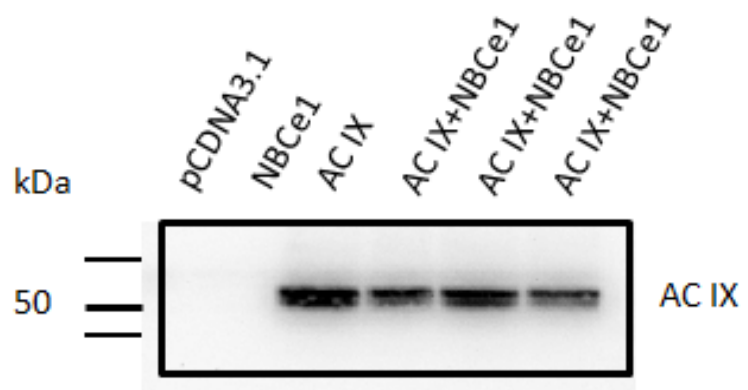

Figura II.4: Coinmunoprecipitaciones del complejo NBCe1/AC IX en células HEK293. A. Lisados de células HEK293 transfectadas transitoriamente con NBCe1, AC IX o pCDNA3.1 (vector vacío), fueron utilizados para las inmunoprecipitaciones con un anticuerpo contra AC IX o sin anticuerpo. Las muestras fueron resueltas en un gel de poliacrilamida y reveladas con un anticuerpo específico contra NBCe1. B. Y C. Inmunoblots de células HEK293 transfectadas con NBCe1, AC IX o el pCDNA3.1, incubados con un anticuerpo especifico contra NBCe1 (B) o contra AC IX (C). 
GST pull down

Sabiendo por los experimentos anteriores que la AC IX efectivamente interacciona físicamente con el NBCe1, quisimos caracterizar cual es la región donde la AC IX se une al cotransportador.

Los bucles 3 y 4 , según la topología, son los más grandes del NBCe1 y por lo tanto los grandes candidatos en interaccionar con AC IX. Además, se ha demostrado que el bucle extracelular 4 del intercambiador aniónico 1 (AE1) es capaz de interaccionar con la AC IX. Por lo tanto, generamos proteínas de fusión, en las cuales las secuencias proteicas de cada uno de los dos grandes bucles fueron fusionadas con la secuencia de la proteína glutatión-S-transferasa (GST): GST-AE1EC4, GST-NBCe1EC3 y GST-NBCe1EC4. Estas proteínas de fusión fueron incubadas por separado con lisados de células HEK293 transfectadas con AC IX o sin transfectar y con una resina que posee en su superficie el tripéptido glutatión. Luego de la incubación y posterior centrifugación, las proteínas unidas a la resina se eluyeron con el buffer de carga (buffer-SDS-PAGE). En la figura II.5, podemos observar los inmunoblots, utilizando un anticuerpo específico contra AC IX.

Se encontró que el bucle 4 del NBCe1 es capaz de unirse a AC IX y precipitarla, al igual que en el caso del AE1. Por el contrario no se halló ninguna banda correspondiente a AC IX en el lisado del bucle 3. Se ha demostrado que el AE2 y el AE3 interaccionan con la AC IX y, además, en base a la alineación de las secuencias de aminoácidos, muestran una similitud en la región de los bucle 4 para el AE3, AE2, AE1 y el NBCe1. Por lo tanto podemos inferir que el NBCe1 interacciona físicamente con la AC IX a través de su bucle extracelular 4. 


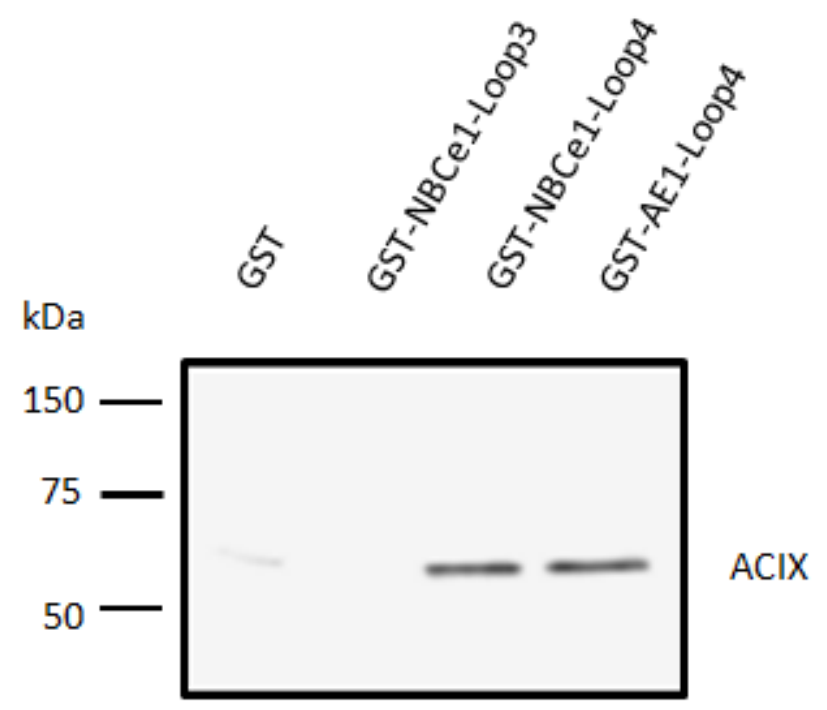

Figura II.5: Ensayo GST pull down. Células HEK293 fueron cotransfectadas con la AC IX y con cada una de las proteínas de fusión correspondientes al bucle extracelular 3 del NBCe1, (GST-NBCe1-Loop3), el bucle extracelular 4 del NBCe1 (GST-NBCe1-Loop4), como control positivo el bucle extracelular 4 del AE1 (GST-AE1-Loop4) y negativo sólo GST.

\section{Colocalización por inmunofluorescencia y microscopía confocal}

Mediante la técnica de inmunofluorescencia se estudió la localización subcelular y la interacción física de la AC IX y el NBCe1 en miocitos aislados de rata y en células HEK293 cotransfectadas con cada una de las proteínas de interés.

Se encontró marcación correspondiente a NBCe1 en los túbulos-t y en la membrana sarcolemal, consistente a datos previos hallados por nuestro laboratorio en miocitos aislados de gato [25]. La AC IX al igual que el NBCe1 se encontró en los túbulos-t, sin embargo no se halló marcación en el sarcolema. Coherentemente con los datos encontrados por las coinmunoprecipitaciones, la combinación de las fluorescencias resultó que la AC IX y el NBCe1 colocalizan en los túbulos-t de los cardiomiocitos. 
La especificidad de la marcación se corroboró por la ausencia de señal cuando los miocitos fueron tratados únicamente con el anticuerpo secundario, en ausencia del anticuerpo primario.

Se cuantificó la superposición de pixeles rojos (AC IX) y verdes (NBCe1) mediante el programa de computadora Image Pro Plus ${ }^{\circledR}$. En la figura II.6 Se muestra el grado de asociación a través del coeficiente de correlación de Pearson ( $r$ ). Un r mayor a 0.7 indica una asociación fuerte. El grado de colocalización encontrado entre NBCe1 y AC IX en cardiomiocitos fue de $0.89 \pm 0.01(n=6)$. Algo similar ocurrió cuando se estudió la colocalización en células HEK293 cotransfectadas con NBCe1 y AC IX $(0.85 \pm 0.01, n=9)$.

NBCe1

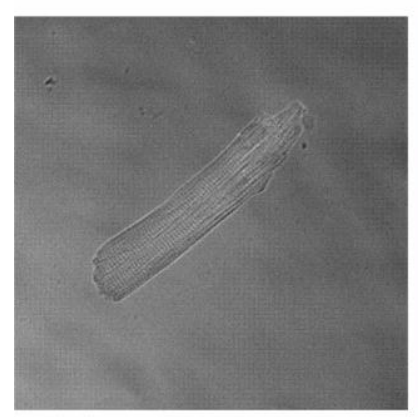

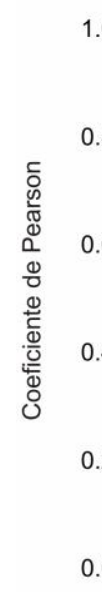
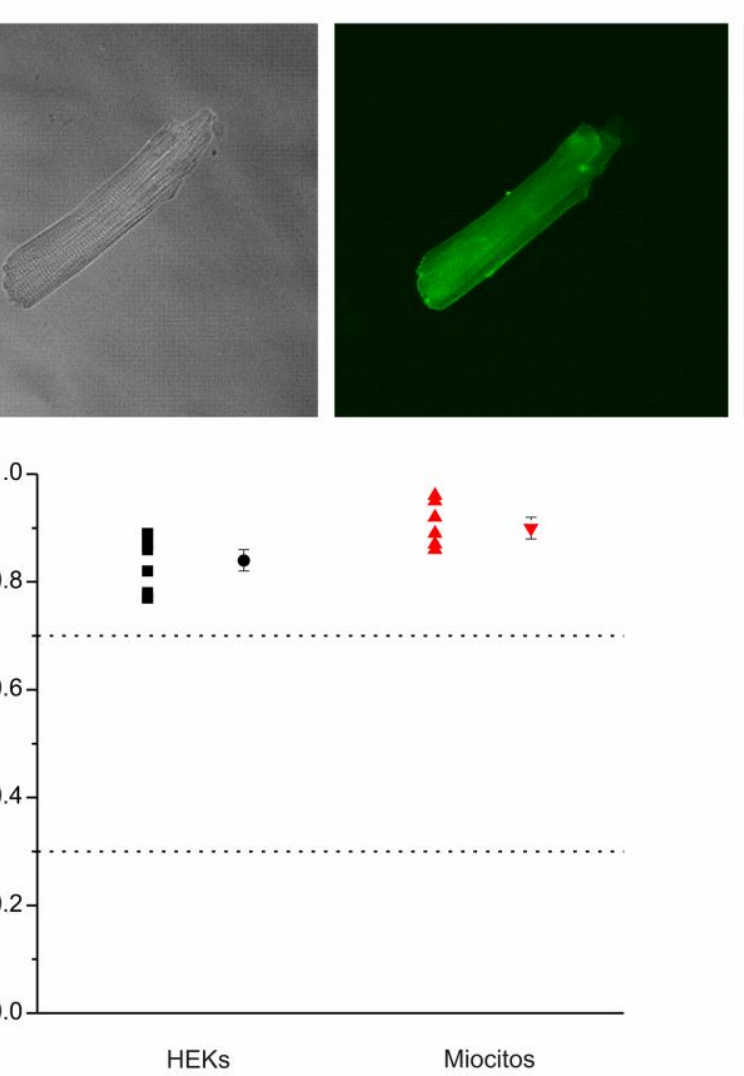

$\mathrm{AC} I \mathrm{X}$
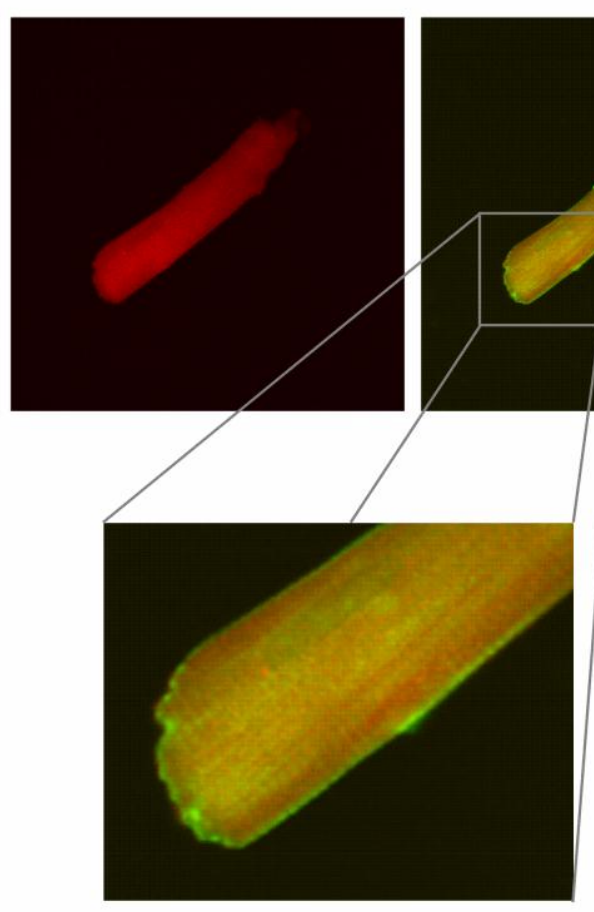

Merge

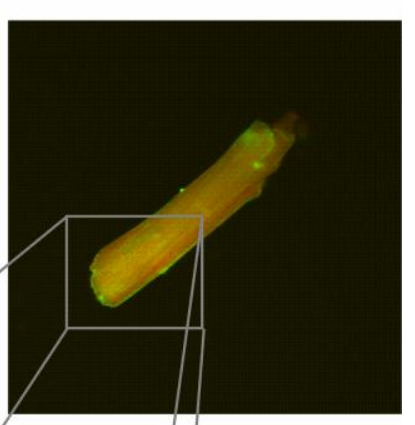

Figura II.6: Colocalización por microscopía confocal. Miocitos aislados de rata fueron incubados con los anticuerpos primarios para NBCe1 (a-L4 NBCe1; dilución 1:100, conejo policlonal) y para AC IX (1:100, ratón monoclonal). Se utilizó anticuerpos secundarios conjugados con fluorocromos para su posterior visualización en un microscopio confocal Zeiss LSM 410, objetivo de inmersión en aceite X60/1.3. (Alexa Fluor 488 IgG anti conejo (1:100) y Alexa Fluor 594 IgG ratón (1:100). Se utilizó el programa Image Pro Plus ${ }^{\circledR}$ para cuantificar el grado de colocalización en cardiomiocitos y células HEK293 a través del cálculo del coeficiente de correlación de Pearson ( $r$ ). 
Si bien existen limitaciones en los sistemas ópticos como los usados en estos experimentos, estos resultados demuestran que el NBCe1 y AC IX se encuentran formando un complejo físico en los túbulos-t sugiriendo un rol significativo en el acoplamiento excito/contráctil de los cardiomiocitos.

\section{II.6 Regulación funcional del cotransportador NBCe1 por las anhidrasas carbónicas en cardiomiocitos}

\section{Pulsos de $\mathrm{K}^{+}$}

Para medir la actividad del NBCe1 de manera aislada se realizaron experimentos de epifluorescencia en miocitos ventriculares de rata, cargados con el indicador de pH BCECF-AM, los cuales se sometieron a una despolarización del potencial de membrana de aproximadamente $60 \mathrm{mV}$, mediante la elevación del $\mathrm{K}^{+}$extracelular desde 4.5 a $45 \mathrm{mM}$ (ver materiales y métodos, pulso de $K^{+}$), destinada a incrementar únicamente la fuerza impulsora del NBCe1 [35]. Se utilizó como medida de la actividad del NBCe1, la diferencia de pH entre el tiempo 0 y los 14 min de exposición al alto $\mathrm{K}^{+}$.

Se estudió el correlato funcional de la interacción física demostrada en los experimentos anteriores, realizando pulsos de $\mathrm{K}^{+}$en presencia y ausencia de 2 inhibidores de las AC. La etoxizolamida (ETZ), la cual atraviesa libremente la membrana plasmática, y la benzolamida (BZ) que no la atraviesa, por lo tanto sólo inhibe las AC extracelulares.

El incremento de $\mathrm{pH}_{\mathrm{i}}$ control $(0.165 \pm 0.017, \mathrm{n}=11)$ fue inhibido significativamente por ETZ $100 \mu \mathrm{M}\left(0.053 \pm 0.014, \mathrm{n}=7^{*}\right)$ y en menor medida por BZ $100 \mu \mathrm{M}\left(0.090 \pm 0.025, \mathrm{n}=6^{*}\right)$. Estos resultados indican que la actividad del NBCe1 es maximizada por la actividad de las AC. La diferencia obtenida con los dos bloqueantes podría deberse a la inhibición de la AC II citosólica por ETZ y no por BZ, por su propiedad impermeante. 
A

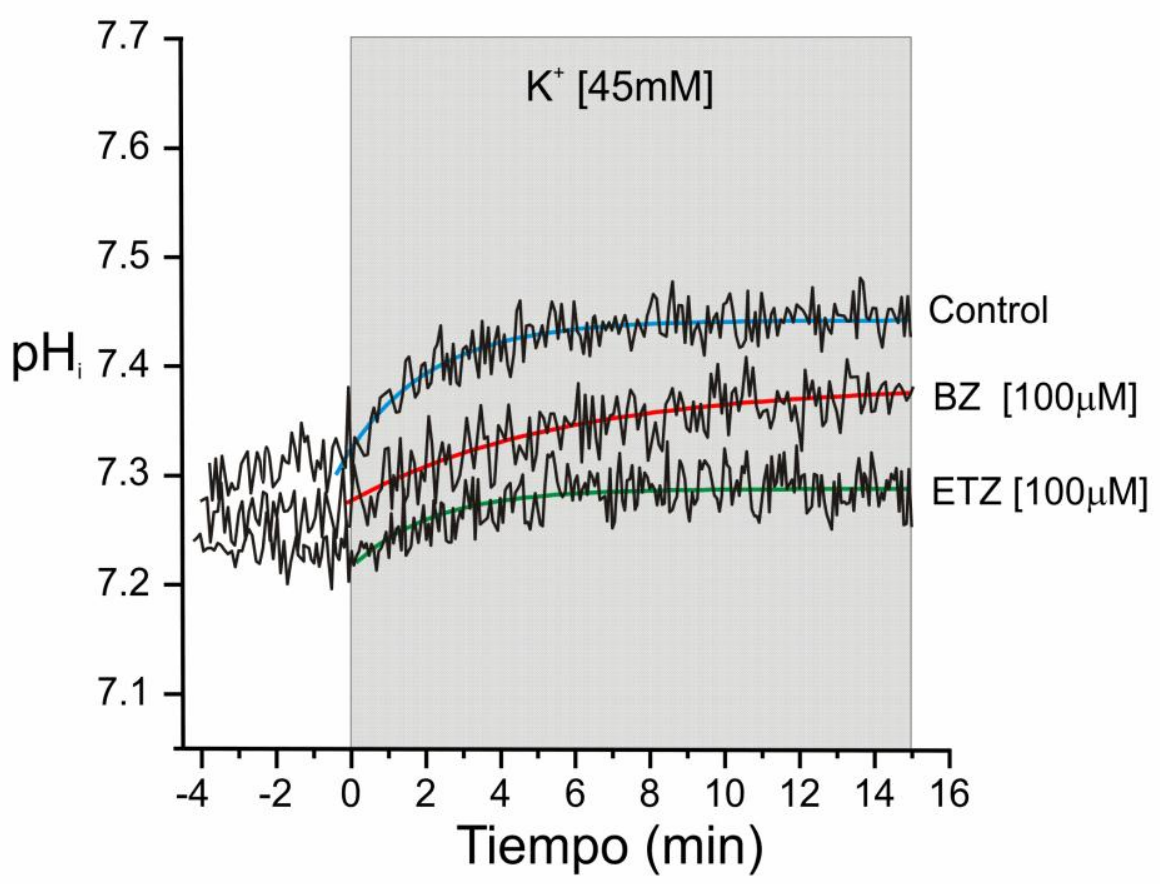

B

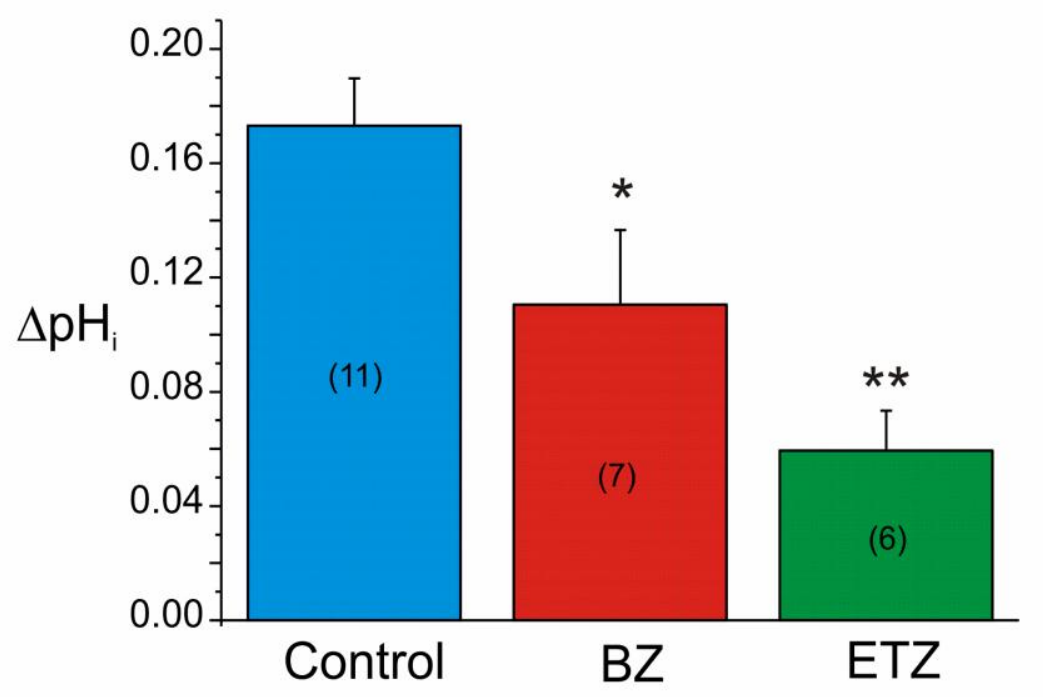

Figura II.7: Pulso de $\mathbf{K}^{+}$con inhibidores de las AC. A. Trazos representativos de los pulsos de $\mathrm{K}^{+}$, en condiciones control y en presencia de los inhibidores de las AC, ETZ y BZ. B. Datos promedios del JH a pH 6.8. Entre paréntesis se detallan el número de experimentos realizados. ${ }^{*}$ Control vs $B Z(p<0.05) ;{ }^{* *} B Z$ vs ETZ ( $p<0.05)$. 
Pulsos de $\mathrm{NH}_{4}^{+}$

La actividad total del NBC (NBCe1 + NBCn1) se estudió mediante pulsos de $\mathrm{NH}_{4}^{+}$para inducir una acidosis intracelular (ver materiales y métodos, Pulso de $\mathrm{NH}_{4}^{+}$). Se calculó el flujo de $\mathrm{H}^{+}(\mathrm{JH}, \mathrm{mM} / \mathrm{min})$ a $\mathrm{pH}_{\mathrm{i}} 6.8$, en presencia y ausencia de bloqueantes de las AC, ETZ y BZ.

Para independizarnos de la actividad del intercambiador $\mathrm{Na}^{+} / \mathrm{H}^{+}$(NHE1) los experimentos siempre se realizaron en presencia de $10 \mu \mathrm{M}$ de HOE642, un inhibidor selectivo del NHE1. Demostramos que esta concentración de HOE642 era suficiente para bloquear en su totalidad la actividad del NHE1 en cardiomiocitos de rata. Para ello, hicimos pulsos de $\mathrm{NH}_{4}^{+}$en un buffer en ausencia de $\mathrm{HCO}_{3}{ }^{-}$, donde el único mecanismo alcalinizante es el $\mathrm{NHE1}$, y en presencia de HOE642. Luego de la acidificación no se evidenció ningún tipo de recuperación de la sobrecarga ácida. Pasados 20 minutos se modificó la perfusión por el mismo buffer pero en ausencia de HOE642, comprobándose así la recuperación mediada por NHE1 (figura II.8).

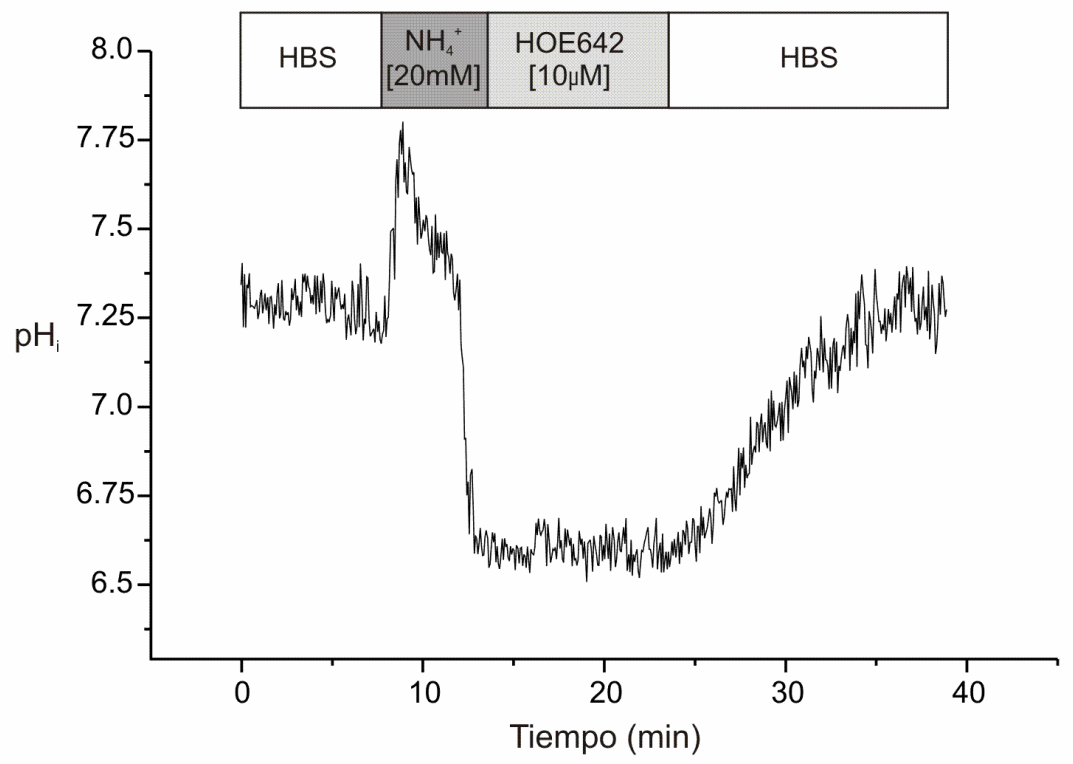

Figura II.8: Pulso de $\mathrm{NH}_{4}^{+}$con $\mathrm{HOE} 10 \mu \mathrm{M}$ y en ausencia de $\mathrm{HCO}_{3}^{-}$. En la figura se observa la inhibición total del intercambiador $\mathrm{Na}^{+} / \mathrm{H}^{+}$por la presencia de $\mathrm{HOE}$. Luego de 20 minutos se lava el inhibidor corroborándose la funcionalidad del NHE1.

En la figura II.9 se observa la recuperación de los miocitos a una sobrecarga ácida. El flujo de $\mathrm{H}^{+}{\mathrm{O} \mathrm{HCO}_{3}}^{-}$disminuyó significativamente por los inhibidores de las $\mathrm{AC}\left(\mathrm{JH}\right.$ a $\mathrm{pH}_{\mathrm{i}} 6.8$, 
Control: $3.74 \pm 0.45, n=6 ; \quad E T Z: 1.79 \pm 0.38, n=5 ; B Z: 2.29 \pm 0.43, n=5 ; * p<0.05)$. En estos experimentos no podemos distinguir cual es la isoforma involucrada, sin embargo, demuestran una vez más la colaboración de las ACs en el transporte de $\mathrm{HCO}_{3}{ }^{-}$mediado por $\mathrm{NBC}$ en miocitos cardíacos de ratas.

A

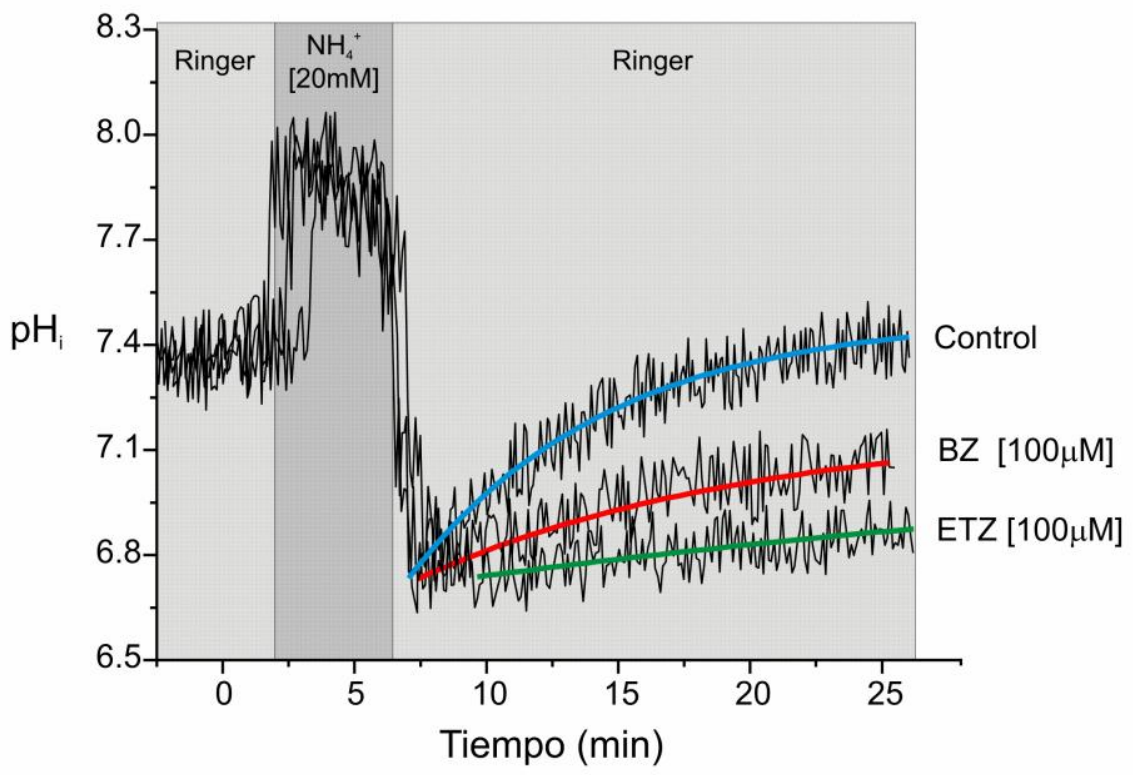

B

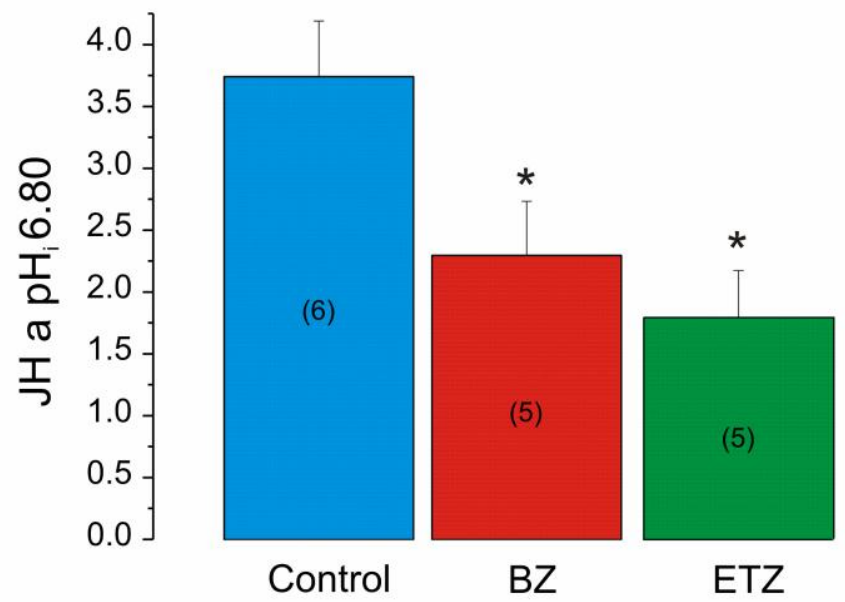

Figura II.9: Pulso de $\mathrm{NH}_{4}{ }^{+}$con inhibidores de las AC. A. Se observa los trazos representativos de los pulsos de $\mathrm{NH}_{4}{ }^{+}$en presencia de $\mathrm{BZ}$, ETZ y el control, claramente se evidencia una disminución del transporte mediado por NBC debido a la inhibición de las AC. B. Datos promedios del JH a pH 6.8. Entre paréntesis se detallan el número de experimentos realizados. ${ }^{*}(p<0.05)$. 


\section{II.7 Regulación funcional del cotransportador NBCe1 por las anhidrasas en un sistema de expresión heterólogo (HEK293)}

Se estudió la interacción funcional en la línea celular HEK293, las cuales no expresan endógenamente ni NBCe1 ni AC IX, como se observan en los inmunoblots de la figura II.4. Células cotransfectadas transitoriamente con NBCe1 y AC IX o sólo con NBCe1 y sólo con AC IX fueron cargadas con el indicador fluorescente de pH BCECF-AM al igual que los cardiomiocitos. Luego de una sobrecarga ácida generada por el lavado de una solución con $\mathrm{NH}_{4}{ }^{+}$(ver materiales y métodos), se midió el flujo inicial de $\mathrm{HCO}_{3}{ }^{-}$en la recuperación del $\mathrm{pH}_{\mathrm{i}}$.

Las células HEK293 expresan NHE1 y además en mayor medida NHE3. Por lo tanto, en todos los experimentos se utilizó un inhibidor que bloquea varias isoformas del NHE como el EIPA (5-(N-ethyl-N-isopropyl)-amiloride). Determinamos que $30 \mu \mathrm{M}$ de EIPA es la concentración necesaria para independizarnos de la actividad mediada por NHE en células HEK293, ya que en ausencia de $\mathrm{HCO}_{3}{ }^{-}$extracelular (Buffer $\mathrm{HBS}$ ) se abolió la recuperación del $\mathrm{pH}_{\mathrm{i}}$ luego de la acidosis (figura II.10).

A

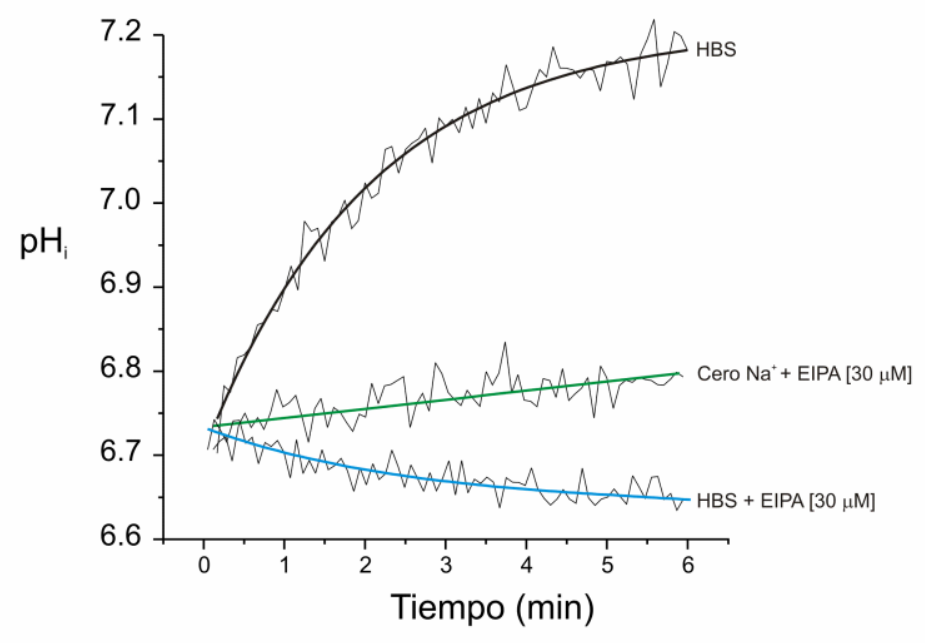

B

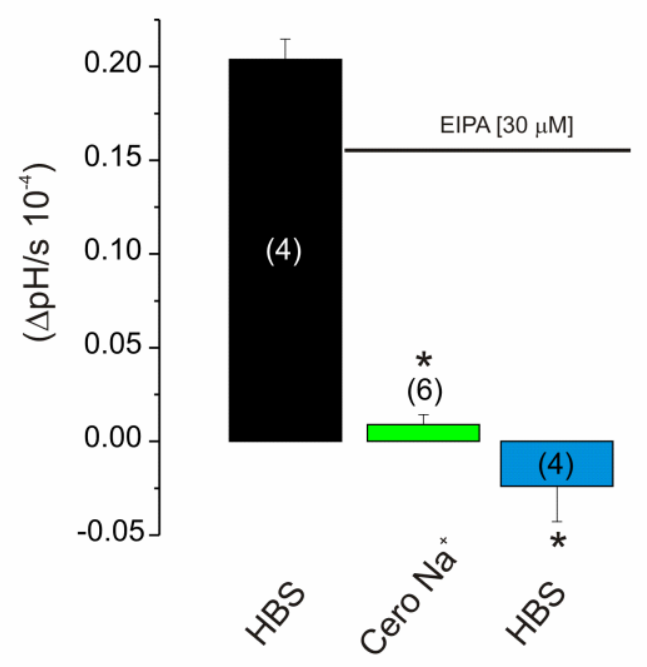

Figura II.10: Recuperación de una sobrecarga ácida en células HEK293. A. Se observan los trazos representativos de los pulsos de $\mathrm{NH}_{4}{ }^{+}$en células HEK293. B. Datos promedio de la velocidad inicial de recuperación. Entre paréntesis se detallan el número de experimentos realizados. ${ }^{*}(p<0.05)$. 
En presencia de $\mathrm{HCO}_{3}{ }^{-}$extracelular y EIPA, la recuperación de la acidosis aumentó como era de esperar, cuando las células se transfectaron con el plásmido que posee el gen para NBCe1. Este aumento fue de $3.05 \pm 0.52 \mathrm{mM} \cdot \mathrm{min}^{-1}(\mathrm{n}=7)$ (figura II.11). Interesante fue el resultado obtenido cuando se cotransfectaron con NBCe1 y $A C$ IX, ya que el transporte aumentó en casi 4 veces $\left(12.1 \pm 0.45 \mathrm{mM} \mathrm{min}^{-1}, \mathrm{n}=9\right)$ en comparación con sólo la transfección con NBCe1.

Utilizando el inhibidor impermeante BZ en células transfectadas con NBCe1, se confirmó por un lado que no existe expresión endógena de las AC extracelulares en la línea celular y además, que dicho inhibidor no posee una acción directa sobre NBCe1 (figura II.11.B). Se estudió el transporte en presencia de BZ cuando las células se cotransfectaron con NBCe1 y AC IX obteniendo una reducción parcial del transporte mediado por NBCe1 (7.53 $\pm 0.29 \mathrm{mM} \cdot \mathrm{min}^{-1}$, $\mathrm{n}=9$ ), lo cual indica que $\mathrm{AC}$ IX incrementa el flujo de $\mathrm{HCO}_{3}{ }^{-}$catalizado por NBCe1.

A

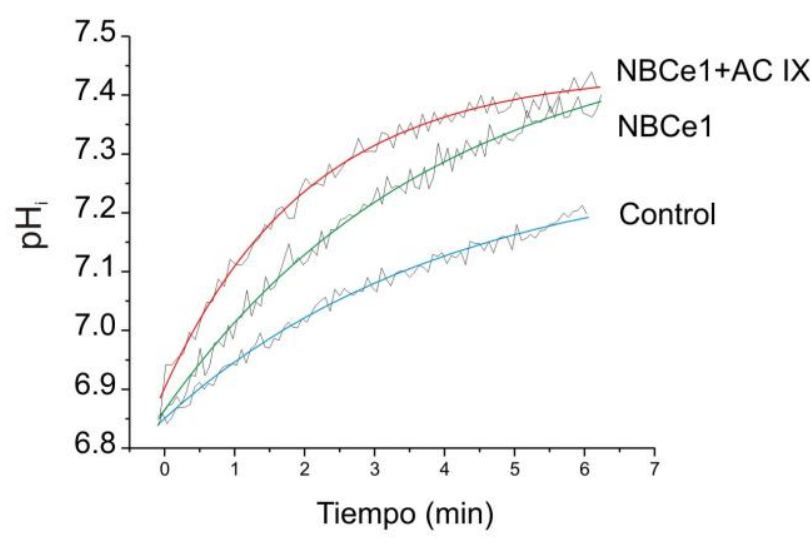

B

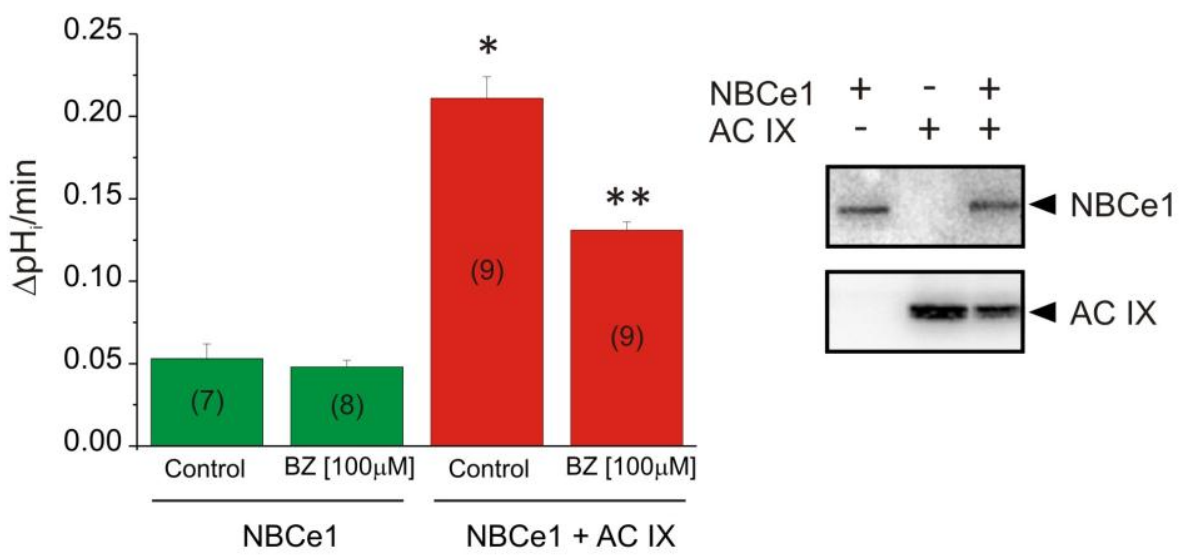

Figura II.11: Recuperación de una sobrecarga ácida en células HEK293 transfectadas con NBCe1 y AC IX. A. Registros de la recuperación del $\mathrm{pH}_{\mathrm{i}}$ en células HEK293 luego de una acidificación por un pulso de $\mathrm{NH}_{4}{ }^{+}$siempre en presencia de $10 \mu \mathrm{M}$ de EIPA. Trazos representativos en situación control (células sin transfectar), transfectadas con NBCe1y cotransfectadas con NBCe1 + AC IX. B. Datos promedio de la velocidad máxima de recuperación. Entre paréntesis se detallan el número de experimentos realizados. Control (NBCe1) vs Control (NBCe1+AC IX), *(p<0.05); Control (NBCe1+AC IX) vs BZ (NBCe1+AC IX), $* *(p<0.05)$. Inmunoblots correspondientes a un set de células transfectadas en cada una de las condiciones (inset). 
El inhibidor BZ, ha sido cuestionado por su potencial habilidad de bloquear la actividad de las AC intracelulares. Por lo tanto, quisimos asegurarnos que parte del efecto que hallamos no se debe a una inhibición de la AC II por la BZ. Para eso diseñamos un experimento, en donde células HEK293 sin transfectar, que inicialmente se encontraban en una solución HEPES (sin $\mathrm{HCO}_{3}{ }^{-}$), son expuestas a una solución con $\mathrm{HCO}_{3}{ }^{-}$burbujeada con $5 \%$ de $\mathrm{CO}_{2}$ (figura II.12). Cuando esto ocurre parte del $\mathrm{CO}_{2}$ disuelto difunde por la membrana plasmática y en el interior celular se conjuga con el $\mathrm{H}_{2} \mathrm{O}$ para dar $\mathrm{HCO}_{3}{ }^{-} \mathrm{y} \mathrm{H}^{+}$. Este aumento de $\mathrm{H}^{+}$provoca que la célula se acidifique.

La velocidad de la acidificación, en las células HEK293, sólo dependerá de la AC II citosólica, por lo tanto, esta velocidad se reducirá si es inhibida. Como era de esperar, el inhibidor capaz de permear la membrana celular, la ETZ, disminuye significativamente la velocidad de acidificación cuando las células son expuestas a $\mathrm{CO}_{2} / \mathrm{HCO}_{3}^{-}$(figura II.12). Sin embargo, en presencia de BZ la velocidad de acidificación no fue diferente al control, lo que indica, que al menos en nuestras condiciones experimentales, la BZ no atraviesa la membrana.

Los resultados obtenidos en esta primera parte del trabajo, demuestran que el NBCe1 y AC IX forman un complejo físico-funcional involucrado en la regulación del metabolismo de $\mathrm{HCO}_{3}{ }^{-}$y la regulación del $\mathrm{pH}_{\mathrm{i}}$ en el corazón. 
A

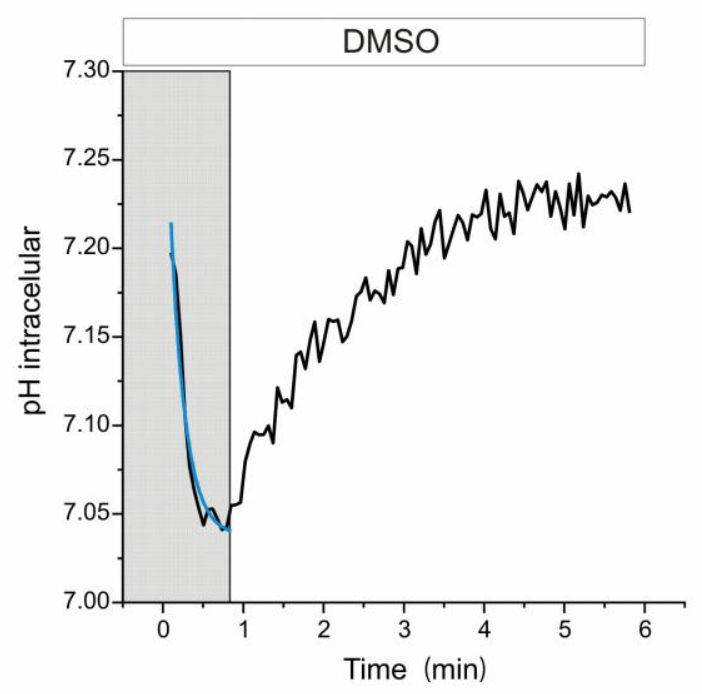

C

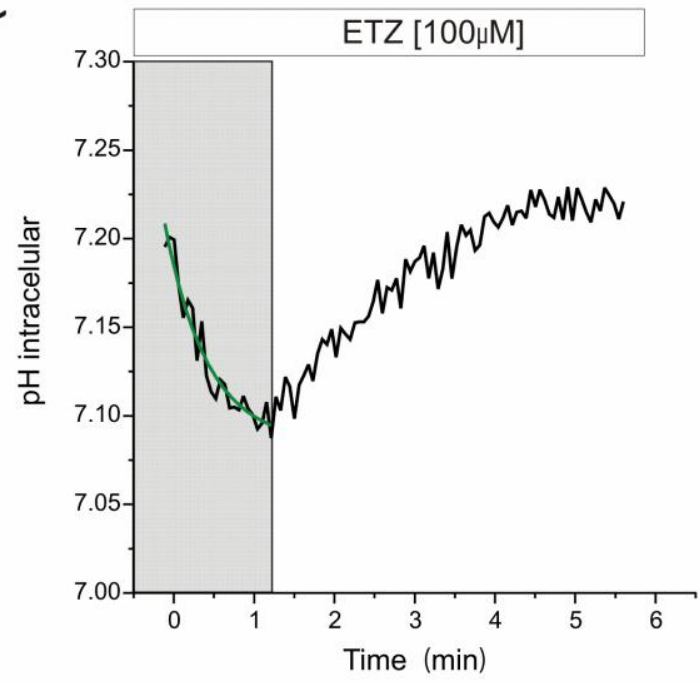

B

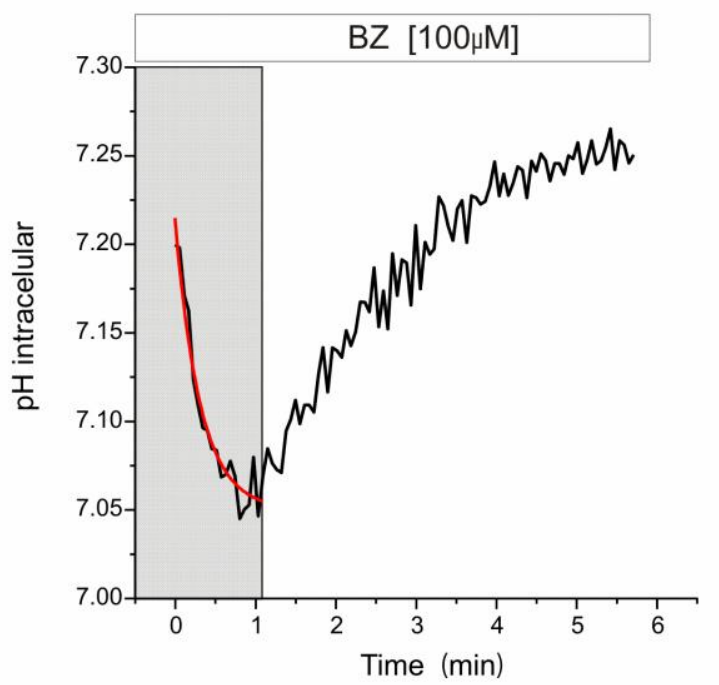

D

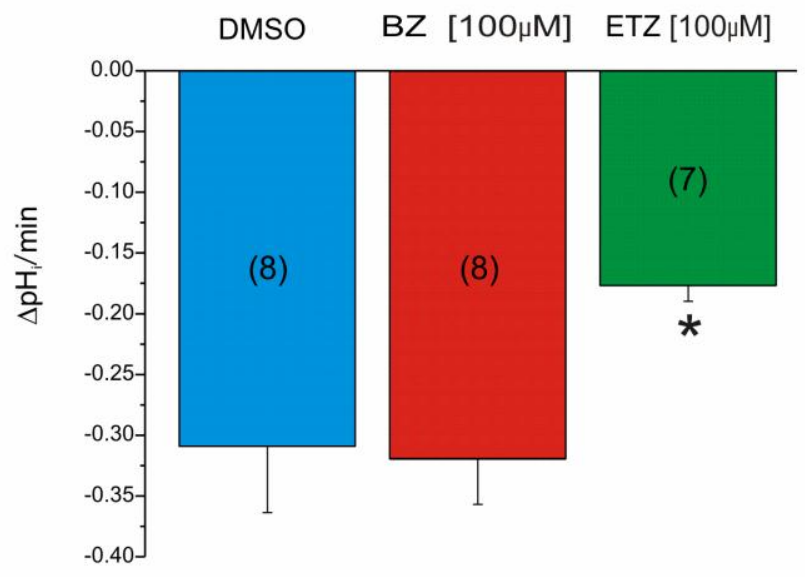

Figura II.12: Efecto de la BZ sobre la AC intracelular de las HEK293. A, B y C. Trazos representativos de $\mathrm{pH}_{\mathrm{i}}$ luego de ser expuestas células HEK293 a 5\% de $\mathrm{CO}_{2}$. Se observa la acidificación intracelular (rectángulo gris) seguida de la recuperación normal del $\mathrm{pH}_{\mathrm{i}}$. A. condición control, sin inhibidor. B. En presencia del inhibidor impermeante a la membrana celular, BZ. C. En presencia del inhibidor ETZ que atraviesa libremente la membrana celular. D. Datos promedio de la velocidad máxima de acidificación en cada una de las tres condiciones (rectángulo gris). Entre paréntesis se detallan el número de experimentos realizados. ${ }^{*}(p<0.05)$. 


\section{II.8 Discusión}

En la primer parte de este trabajo doctoral exploramos la posible regulación del cotransporte $\mathrm{Na}^{+} / \mathrm{HCO}_{3}{ }^{-}$electrogénico o NBCe1 por la AC IX en el miocardio. Demostramos que la AC IX efectivamente interacciona física y funcionalmente con el NBCe1 cardíaco, basándonos en los resultados obtenidos por las coinmunoprecipitaciones y por las medidas de actividad del NBCe1.

Además, se demostró que AC II y AC IV interacciona físicamente con el NBCe1 en corazón, consistente con los datos hallados por otros autores en diferentes sistemas de expresión.

A través de ensayos de inmunofluorescencia y el análisis por microscopía confocal se encontró que AC IX colocaliza con el NBCe1 únicamente en los túbulos-t. Si bien en este trabajo no fue estudiado la localización celular de la AC IV, se ha descripto que permanece confinada en la membrana sarcolemal del músculo esquelético [75], y no sobre los túbulos-t, sugiriendo una diferencia funcional entre ambas isoformas.

Finalmente, describimos que el bucle extracelular 4, que se encuentra entre los dominios transmembranas 7 y 8 , es la región física del NBCe1 encargada de interaccionar con la AC IX.

Estudios realizados en células parietales mostraron sobre la membrana basolateral la interacción funcional del intercambiador $\mathrm{Cl}^{-} / \mathrm{HCO}_{3}{ }^{-}-2$ (AE2) con el dominio catalítico de la AC IX [76]. En este trabajo mostramos por primera vez la interacción física y funcional que existe entre la AC IX y el NBCe1 en cardiomiocitos de rata. Es conocida la importancia fisiológica de los túbulos-t en el acoplamiento excito-contráctil, por lo que la constante acumulación de $\mathrm{H}^{+}$ debido a la actividad contráctil del músculo cardíaco debe ser eficientemente disipada (figura II.13). Además, demostramos la importancia funcional que posee el acoplamiento entre CA IX y NBCe1, el cual maximiza la capacidad de regular el $\mathrm{pH}_{\mathrm{i}}$ de la célula. Proponemos que la actividad enzimática de la AC IX proporciona un incremento en la concentración de $\mathrm{HCO}_{3}{ }^{-}$en el 
microdominio cercano al NBCe1 aumentando la fuerza impulsora y de esta forma el transporte de $\mathrm{HCO}_{3}{ }^{-}$hacia el interior celular. Además, en el interior celular existe la interacción física entre la AC II y el dominio C-terminal del NBCe1. Esta interacción aumentaría el transporte debido a que disminuye la concentración de $\mathrm{HCO}_{3}{ }^{-}$en el interior provocando un efecto de "tira y empuje" (push and pull).

\section{Extracelular}

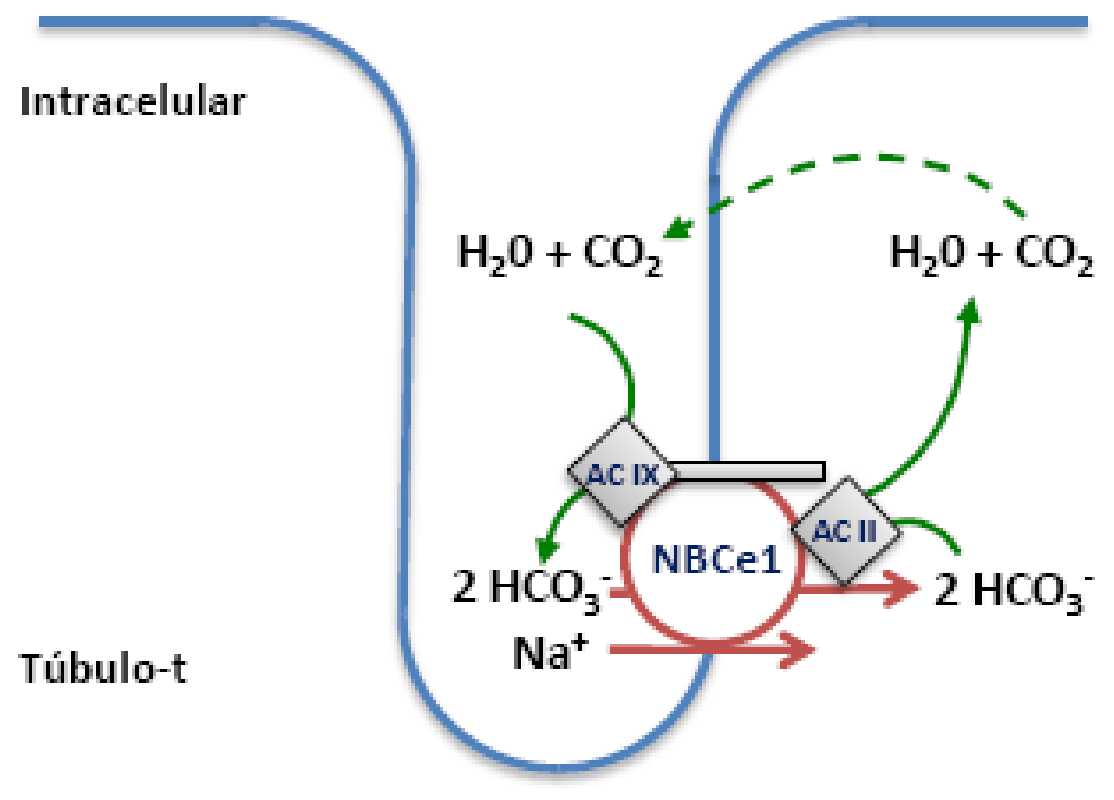

Figura II.13: Esquema representativo del metabolón de transporte iónico. El cotransportador NBCe1 y la AC IX extracelular (anclada en membrana por glicosil-fosfatidil inositol) y la AC II citoplasmática forman un complejo físico y funcional localizado en los túbulos-t de los miocitos cardíacos. La AC IX es la responsable del aumento local de la concentración de $\mathrm{HCO}_{3}{ }^{-}$extracelular. Este aumento, incrementa la fuerza impulsora del $\mathrm{NBCe} 1$ y por lo tanto el influjo de $\mathrm{HCO}_{3}{ }^{-}$. En el interior celular, la $\mathrm{AC}$ II disipa el aumento de $\mathrm{HCO}_{3}{ }^{-}$formando $\mathrm{H}_{2} \mathrm{O}$ y $\mathrm{CO}_{2}$, este último es capaz de difundir libremente a través membrana plasmática.

Utilizamos dos inhibidores de las ACs, la etoxizolamida (ETZ), la cual permea libremente la membrana celular y por lo tanto bloquea las ACs extracelulares como las citoplasmáticas, y la benzolamida (BZ), cuya incapacidad de atravesar a la membrana plasmática se ha demostrado 
en este trabajo. Por lo tanto, la BZ sólo inhibirá las ACs extracelulares. La inhibición con ETZ redujo en un $70 \%$ la actividad mediada por NBCe1, mientras que el bloquear las ACs extracelulares con BZ disminuyó en $45 \%$ su actividad. Por lo tanto, gracias a estos bloqueantes, demostramos la importancia del complejo funcional AC IX O ACIV-NBCe1-ACII en cardiomiocitos.

Se ha descripto que la AC IV interacciona con el NBCe1 a través del bucle extracelular 4, el cual se encuentra entre los dominios trasmembranas 7 y 8 . Justamente en el DT 8 se encuentra el sitio de formación del poro de translocación de los iones. En este trabajo encontramos que al igual que la AC IV, la AC IX interacciona con el NBCe1 a través del bucle extracelular 4 (Loop 4). Se ha demostrado la importancia de los bucles 3 y 4 como fundamentales en la regulación del NBCe1. En trabajos previos desarrollamos anticuerpos dirigidos al bucle 3 obteniendo una inhibición total del transporte mediado por NBCe1 [25]. Por otro lado, anticuerpos dirigidos contra el bucle 4 poseen efectos totalmente opuestos: estimula la actividad mediada por NBCe1 [25], sugiriendo que dicha región es fundamental en la regulación del NBCe1. 


\section{III}

\section{Regulación hormonal del cotransporte $\mathrm{Na}^{+} / \mathrm{HCO}_{3}{ }^{-}$por la aldosterona}

\section{III.1 Introducción}

La aldosterona es una hormona esteroidea de la familia de los mineralocorticoides. Es secretada principalmente por la zona glomerular de la corteza adrenal, y desde hace muchos años, se la ha involucrado en la regulación de la presión sanguínea. Los principales efectos descriptos para la aldosterona son sobre el riñón, más precisamente sobre los túbulos distales del nefrón, donde aumenta la reabsorción de $\mathrm{Na}^{+}, \mathrm{Cl}^{+}$y $\mathrm{H}_{2} \mathrm{O}$ y la secreción de $\mathrm{K}^{+}$[77].

Gracias a su naturaleza hidrofóbica, la aldosterona difunde fácilmente por la membrana plasmática y se une a un receptor intracelular, el receptor de mineralocorticoides o MR (por sus siglas en inglés, mineralcorticoid receptor), el cual se transloca al núcleo actuando como un factor de transcripción aumentando la expresión de la bomba $\mathrm{Na}^{+} / \mathrm{K}^{+}$ATPasa y canales de $\mathrm{Na}^{+}$ $(\mathrm{ENaC})$ presentes en la membrana basolateral [78]. Además, la aldosterona a través del MR es capaz de incrementar la expresión de la quinasa inducible por suero y glucocorticoides (SGK1) en sólo 15-30 minutos, alcanzando su valor máximo a las 2 horas [79]. Se ha demostrado que la 
actividad de varios canales como así también de transportadores iónicos pueden ser regulados por la SGK1. Utilizando ratones Knockout para SGK1 se describió un importante rol en la regulación en las vías de señalización a nivel renal, al regular la ingesta de sal, el peso renal, la proteinuria y la excreción de $\mathrm{K}^{+}$[80]. Más aun la sobreexpresión en ovocitos de Xenopus laevis produce un aumento significativo de la corriente de $\mathrm{Na}^{+}$a través de $\mathrm{ENaC}$, la activación de la ATP-asa $\mathrm{Na}^{+} / \mathrm{K}^{+}$y del cotransportador $\mathrm{Na}^{+} / \mathrm{K}^{+} / \mathrm{Cl}^{-}[81]$.

Estudios recientes demuestran que la aldosterona no sólo posee efectos genómicos, es decir aquellos que involucran la expresión de una proteína nueva, si no que se han encontrado efectos rápidos no genómicos $[82,83]$.

\section{III.2 Síntesis de la aldosterona}

Los glucocorticoides como la corticosterona y los mineralocorticoides como la aldosterona son sintetizados todos a partir del colesterol, principalmente en la corteza adrenal. Las enzimas de la familia del citocromo P-450 son las encargadas de la mayoría de las reacciones de síntesis. Tanto la aldosterona como la corticosterona comparten la misma vía de síntesis a excepción del último paso [84].

La enzima P-450 11b-hidroxilasa (11b-OHasa) sintetiza corticosterona a partir de 11deoxicorticosterona (DOC) y es principalmente regulada por la hormona adrenocorticotropica (ACTH), en cambio la enzima aldo-sintasa forma aldosterona a partir de DOC y es activada en el riñón principalmente por la Angiotensina II y el aumento del potasio plasmático y más levemente por ACTH y sodio $[85,86]$.

Si bien el principal lugar de síntesis de la aldosterona es la corteza adrenal, se han identificado otros tejidos capaces de sintetizar esta hormona esteroidea [87]. Además, se ha encontrado la expresión de la aldo-sintasa en células endoteliales, células del músculo liso [8890] y en corazón, sugiriendo una producción local de aldosterona [91]. 


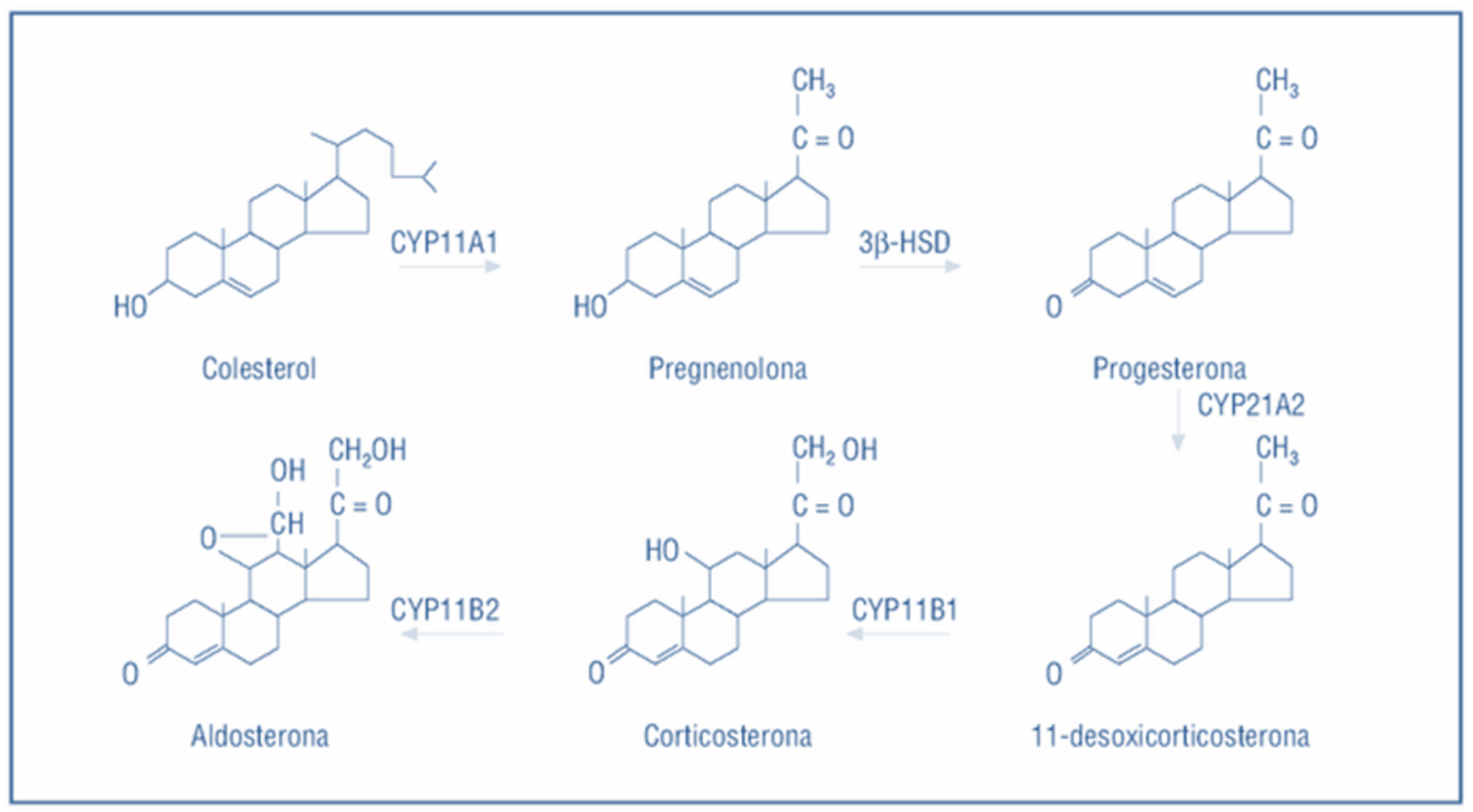

Figura III.1: Esquema de la ruta de síntesis de la aldosterona.

\section{III.3 Efectos rápidos (no genómicos) de la aldosterona}

En los últimos años, se han demostrado diferentes efectos rápidos ejercidos para el mineralocorticoide aldosterona en varios tejidos y sistemas celulares. La aldosterona puede influenciar en los niveles de varios segundos mensajeros como AMPc, DAG, IP3 y Ca ${ }^{2+}$, así como también la activación de proteínas quinasas, en sólo apenas unos minutos [92]. Dichos efectos no pueden ser inhibidos por bloqueantes de la transcripción o traducción, demostrando un efecto no genómico. En células epiteliales de ratones Knockout para el receptor MR se ha descripto un incremento rápido de $\mathrm{Ca}^{2+}$ y AMPc luego de la estimulación por aldosterona [93] sugiriendo que los efectos rápidos de la aldosterona son independientes del MR y que existe un receptor alternativo. Además, se detectó una proteína de membrana capaz de unir a la aldosterona con una afinidad 10 veces mayor que el MR y sin la capacidad de unir cortisol [94]. 
Si bien la proteína en ese momento no fue capaz de ser identificada, se demostró que pertenecía a la familia de los receptores asociados a proteínas G [95].

Recientemente, en nuestro laboratorio se ha demostrado que la aldosterona activa al intercambiador $\mathrm{Na}^{+} / \mathrm{H}^{+}$(NHE1) cardíaco por una vía no genómica [96]. Dicha activación, al contrario de lo expuesto anteriormente, al ser bloqueada por espironolactona y eplerrenona (bloqueantes del MR), parece estar mediada por el MR, transactivando al receptor del factor de crecimiento epidérmico (EGFR). Además, este mecanismo es dependiente de ERO (figura III.2). La hiperactividad del NHE contribuye al desarrollo de hipertrofia y falla cardíaca a través del incremento intracelular de $\mathrm{Na}^{+}$y $\mathrm{Ca}^{2+}$ [96]. Son necesarias más investigaciones para individualizar correctamente al receptor de aldosterona encargado de mediar los efectos no genómicos de la hormona.

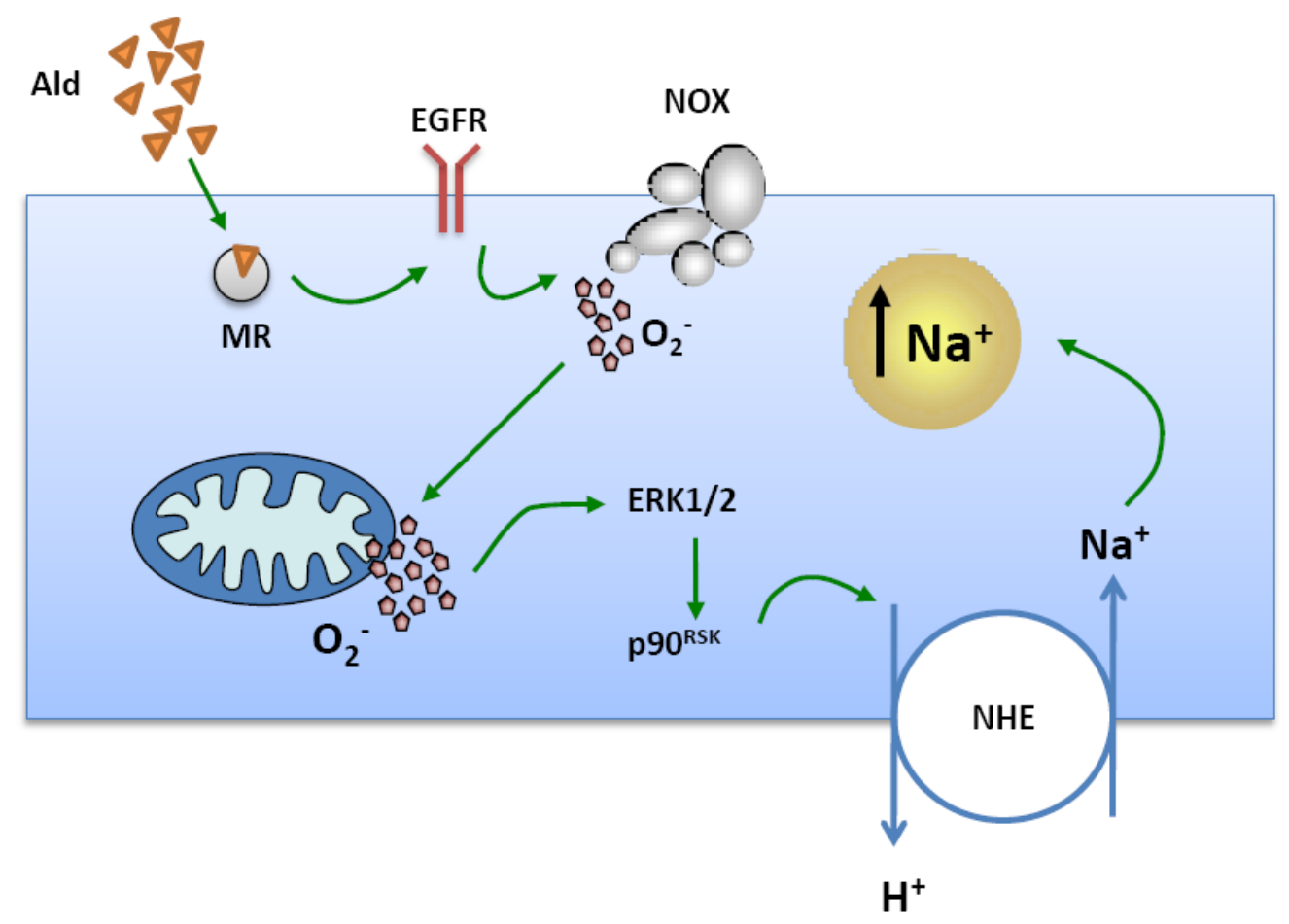

Figura III.2: Efecto de la aldosterona sobre el NHE1 cardíaco. La aldosterona al unirse al MR provoca la transactivación del EGFR, el cual incrementa la producción de ERO a través de la NADPH oxidasa. Grandes cantidades de especies reactivas del oxígeno son liberadas de la mitocondria a través del mecanismos de liberación de ERO inducida por ERO (ROS induce ROS release). El aumento de la actividad del NHE es a través de la activación de la quinasa sensible a ERO, ERK1/2. 


\section{III.4 La aldosterona y el músculo cardíaco}

Las investigaciones sobre la acción de la aldosterona en el músculo cardíaco han ganado especial interés desde el descubrimiento de receptores específicos presentes en los cardiomiocitos y más aun con los recientes ensayos clínicos denominados RALES y EPHESUS [97, 98], que evidenciaron que los antagonistas del receptor MR son beneficiosos en el tratamiento de la insuficiencia cardíaca.

Datos experimentales han revelado que animales expuestos crónicamente a grandes concentraciones de aldosterona sufren daño miocárdico independientemente del aumento de la presión arterial. Estos estudios demostraron que la fibrosis causada por la aldosterona es prevenida por la administración de antagonistas del MR.

La aldosterona promueve fibrosis cardíaca, hipertrofia y muerte celular con el consecuente aumento del estrés oxidativo y el incremento de las señales pro-inflamatorias [99]. Se ha demostrado en miocitos neonatos que la administración de aldosterona de forma crónica provoca hipertrofia celular, un incremento en la concentración de $\mathrm{Na}^{+}{ }_{\mathrm{i}}$ y la sobre expresión del intercambiador $\mathrm{Na}^{+} / \mathrm{H}^{+}[100,101]$. Además, la aldosterona posee efectos directos sobre el miocardio al aumentar la producción de especies reactivas del oxígeno (ERO) generadas por la NADPH oxidasa [102, 103].

Estudios recientes sugieren que la proteína quinasa dependiente de $\mathrm{Ca}^{2+} /$ calmodulina (CaMKII) juega un rol importante en la vías intracelulares estimuladas por la aldosterona. El bloqueo de la CaMKII por el inhibidor KN93, la sobreexpresión de la metionina sulfóxido reductasa $\mathrm{A}$ (la cual reduce a la CaMKII oxidada) o la deficiencia de la NAPH oxidasa, previene el daño miocárdico producido por la administración crónica de aldosterona [99].

Si bien los efectos perjudiciales de la aldosterona sobre el miocardio son ampliamente aceptados y reproducidos en diferentes laboratorios y con diferentes modelos experimentales, 
el mecanismo y la vía intracelular por el cual la aldosterona ejerce su acción patológica no ha sido dilucidado.

\section{III.5 GPR30}

El receptor de estrógenos asociado a proteína G (GPR30 o GPER) fue identificado inicialmente como un receptor huérfano hasta el año 2000 donde Filardo et al. postularon al estrógeno como uno de sus posibles ligandos [104]. En el 2011 Gros et al. trabajando con células del músculo liso vascular, involucraron al GPR30 como el responsable de los efectos rápidos producidos por la aldosterona [105]. En ese mismo trabajo describieron que la aldosterona a través del GPR30 produce la fosforilación de ERK, media la apoptosis y la fosforilación de la cadena liviana de miosina (MLC).

Como todos los receptores asociados a proteínas G, el GPR30 posee 7 regiones transmembrana [106]. La unión del ligando provoca la activación de un heterotrímero asociado a guanina (proteína G), la cual se disocia del receptor activando por ejemplo a la adenilato ciclasa o a la fosfolipasa C [107]. El GPR30 es el único receptor de la familia de receptores asociados a proteínas $\mathrm{G}$ que fue localizado en el retículo endoplásmatico en células COS-7 [108]. Sin embargo, Filardo et al. pudieron detectar en la membrana plasmática al GPR30 utilizando células HEK transfectadas. Además, utilizando estradiol-BSA el cual es impermeante a la membrana, demostraron un incremento intracelular de AMPc [109]. Christ et al. mostraron que la aldosterona y no así el estradiol es el agonista fisiológico para el rápido incremento de AMPc en células musculares lisas vasculares [110], ya que se necesitan concentraciones suprafisiológicas de estrógenos para incrementar el AMPc, e inducir cambios en la fosforilación de ERK in vitro en células vasculares. [105].

Deschamps et al. mostraron que la activación del GPR30 a través del agonista sintético específico G1, reduce el tamaño del infarto en experimentos de isquemia/reperfusión en corazones de ratas [111]. La co-administración del agonista del GPR30 y la inhibición de la vía de la PI3K previene los efectos protectores sugiriendo un mecanismo a través de la vía PI3K/AKT. Dicha activación de la vía PI3K a través del receptor GPR30 supone una 
transactivación del receptor EGF [104], así como la activación de la ERK. Bopassa et al. mostraron que la activación del GPR30 reduce el daño en experimentos de I/R en ratones por la inhibición de la apertura del poro de transición mitocondrial a través de la activación de la vía de la ERK [112]. Además, Filice et al. mostraron que la administración de G1 produce la activación de ERK así como también la fosforilación de la eNOS [113].

Lindsey et al. examinaron los efectos de la administración crónica de G1 en ratas ovactomizadas. G1 fue capaz de prevenir la elevación de la presión arterial sistólica que ocurre cuando disminuyen los niveles de estrógeno, sugiriendo que la activación de GPR30 podría colaborar en la función cardiovascular [114]. Consistente con estos resultados, ratones deficientes de GPR30 desarrollan un incremento significativo en la presión arterial [115]. 


\section{III.6 Objetivo General 2}

El segundo objetivo de esta tesis doctoral fue estudiar el efecto modulatorio de la aldosterona sobre el cotransportador $\mathrm{Na}^{+} / \mathrm{HCO}_{3}{ }^{-}$en el tejido cardíaco, describiendo la vía intracelular involucrada.

Objetivos específicos

- Estudiar el efecto de la aldosterona [10nM] en forma aguda sobre la actividad del cotransportador $\mathrm{Na}^{+} / \mathrm{HCO}_{3}{ }^{-}$en miocitos aislados de ratas.

- Evaluar la acción de la aldosterona sobre cada una de las isoformas del cotransportador NBC presente en células cardíacas.

- Describir la participación de las especies reactivas del $\mathrm{O}_{2}$ como intermediario de la vía intracelular.

- Determinar cuál es el receptor al cual la aldosterona se une para ejercer sus efectos no genómicos. 


\section{Resultados}

\section{III.7 Activación del cotransporte $\mathrm{Na}^{+} / \mathrm{HCO}_{3}{ }^{-}$cardíaco por la aldosterona}

La aldosterona está fuertemente implicada en la fisiopatología cardíaca. Tradicionalmente los efectos de la aldosterona se describían únicamente como de origen genómico, no rápidos, tras su unión al receptor MR. Desde la activación de la CaMKII hasta el incremento del transporte del NHE1 cardíaco los efectos no genómicos (efectos rápidos) de la aldosterona tomaron gran relevancia en los últimos años.

Con respecto a la modulación de NBC por la aldosterona, hasta el momento no se ha descripto la acción que posee esta hormona sobre el transportador. Al igual que el NHE1 cardíaco, un incremento en la actividad del NBC provocaría un aumento en la concentración de $\mathrm{Na}^{+}$citosólico lo que conllevaría a un incremento de $\mathrm{Ca}^{2+}$ debido a una disminución de la actividad del NCX en su modo directo o el aumento en su modo reverso.

Por lo expuesto anteriormente, investigamos el efecto que posee la aldosterona sobre el NBC cardíaco. Para ello realizamos la técnica de pulso de $\mathrm{NH}_{4}^{+}$preincubando a los miocitos por 10 min con Ald $10 \mathrm{nM}$. Como podemos observar el la figura III.3, la aldosterona provocó un aumento de la actividad del NBC total de aproximadamente $45 \%$ con respecto al control, efecto que fue inhibido por la Eplerrenona $[1 \mu \mathrm{M}]$ un antagonista del MR (\% del $\Delta \mathrm{J}_{\mathrm{H}}$ : Control $100 \pm 7$, $n=5$; Ald $145 \pm 11, n=8$; Eple $114 \pm 9, n=4$ ). No se evidenció ningún efecto significativo sobre el $J_{H}$ basal en presencia de Eple con respecto al $J_{H}$ control $\left(J_{H}\right.$ control: $1,4 \pm 0.13, n=5 ; J_{H}$ Eple: 1,25 $\pm 0,17, n=4)$. 
A

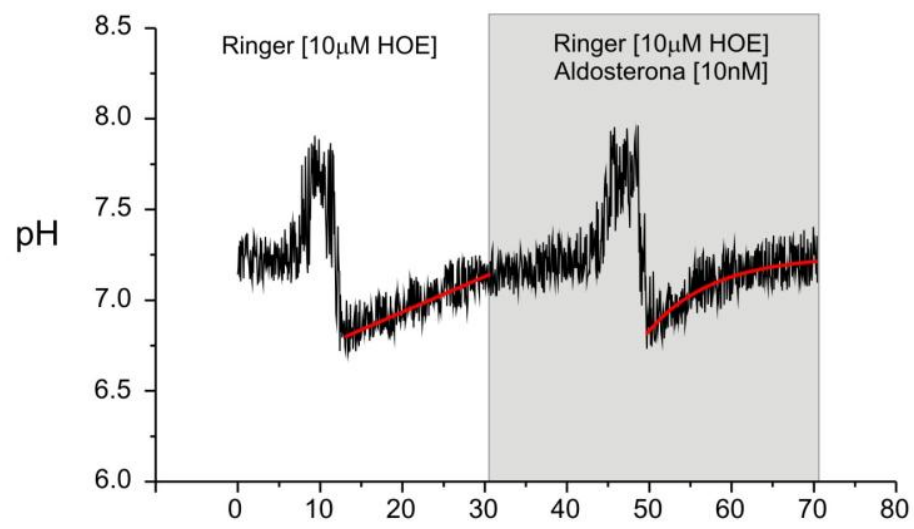

B

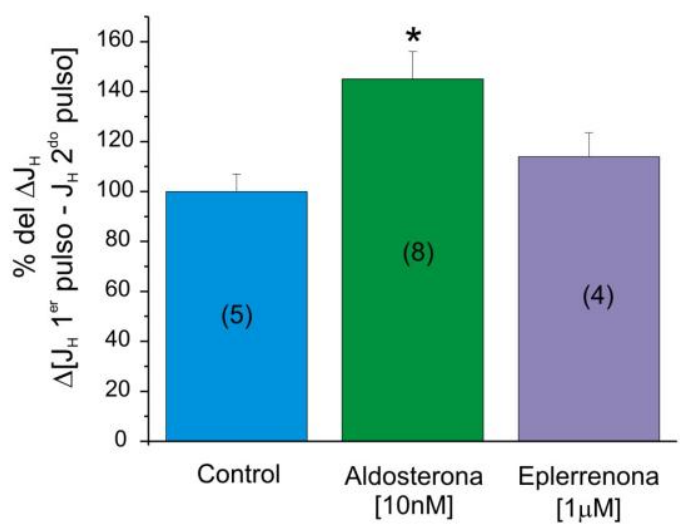

Figura III.3: Efecto de la Aldosterona sobre el NBC cardíaco. A. Se observa los trazos representativos del doble pulso de $\mathrm{NH}_{4}{ }^{+}$control y en presencia de Ald 10nM. En todo momento se utilizó HOE $10 \mu \mathrm{M}$ para inhibir la actividad del NHE. Todas las drogas tuvieron una incubación previa de 10 min antes del pulso de $\mathrm{NH}_{4}{ }^{+}$. B. Barras promedio del \% del $\Delta \mathrm{J}_{H}\left(\mathrm{~J}_{H}\right.$ del 2 do pulso $-\mathrm{J}_{H}$ 1er pulso). Se observa el incremento de la actividad del NBC en presencia de aldosterona y la inhibición por la presencia de Eplerrenona. Entre paréntesis se detallan el número de experimentos realizados. $\left({ }^{*} p<0.05\right.$, respecto al control).

Antes de estudiar cual de las isoformas se encuentra involucrada en la activación del cotransporte por la aldosterona demostramos la presencia de ambas isoformas en el miocito cardíaco de rata, ya que si bien la presencia de la isoforma electrogénica o NBCe1 se encuentra bien caracterizada y aceptada, la presencia de la isoforma electroneutra o NBCn1 ha sido fuertemente cuestionada. Boedtkjer et al. mostraron en ratón la presencia del NBCn1 sólo en el tejido cardíaco auricular y no en el ventricular, sin embargo, nuestro laboratorio demostró la presencia funcional del NBCn1 al utilizar anticuerpos inhibitorios específicos para el NBCe1 en rata y en gato [25].

Utilizamos anticuerpos específicos contra ambas isoformas para determinar la presencia a través de microscopía confocal y Western blots en miocitos aislados ventriculares de rata. Como podemos observar en la figura III.4 se evidencia claramente la presencia de NBCe1 y NBCn1 en los túbulos-t. El análisis por Western-blot muestra la presencia de las bandas correspondiente a NBCe1 y a NBCn1, demostrando una vez más la presencia de ambas isoformas en miocitos ventriculares de rata. 
Podemos observar la especificidad de la marcación por la ausencia de señal cuando los miocitos fueron tratados únicamente con el anticuerpo secundario, en ausencia del anticuerpo primario.
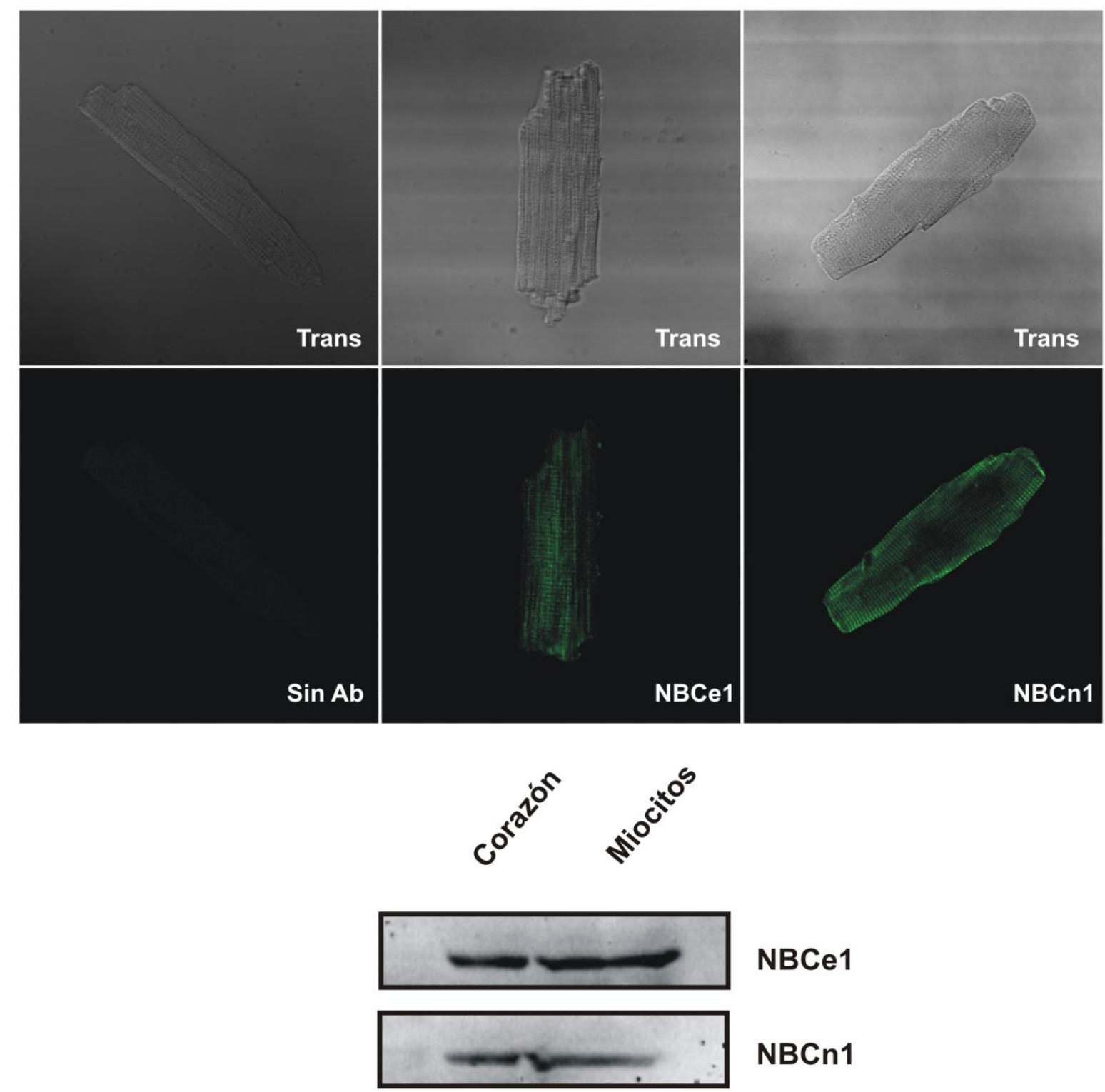

\section{NBCe1}

\section{NBCn1}

Figura III.4: Evidencia de la identidad molecular del NBCe1 y NBCn1 en miocitos cardíacos. En la figura se observa a través de inmunofluorescencia y microscopía confocal la localización del NBCe1 y NBCn1 en túbulos-t de los miocitos ventriculares. Además, se corroboró la expresión de NBCe1 y NBCn1 en miocitos a traves de anticuerpos específicos y la técnica de western-blot 
Mediante la técnica denominada pulso de $\mathrm{K}^{+}$, estudiamos el efecto que posee la Aldosterona sobre la isoforma electrogénica del NBC (NBCe1). En la figura III.5 observamos que la despolarización por altas concentraciones de $\mathrm{K}^{+}$provoca un aumento en la actividad del NBCe1 de 0,18 $\pm 0,01 ; n=19(\Delta \mathrm{pH})$, mientras que en presencia de Ald $10 \mathrm{nM}$ el aumento de la actividad fue el doble $(0,35 \pm 0,05 ; n=8)$. Este efecto de la aldosterona sobre el NBCe1 fue abolido por la presencia de Eplerrenona $1 \mu \mathrm{M}(0,17 \pm 0,04 ; \mathrm{n}=4)$ el antagonista del MR. Estos experimentos nos demuestran que al menos la isoforma electrogénica NBCe1 es regulada positivamente por la presencia de aldosterona.

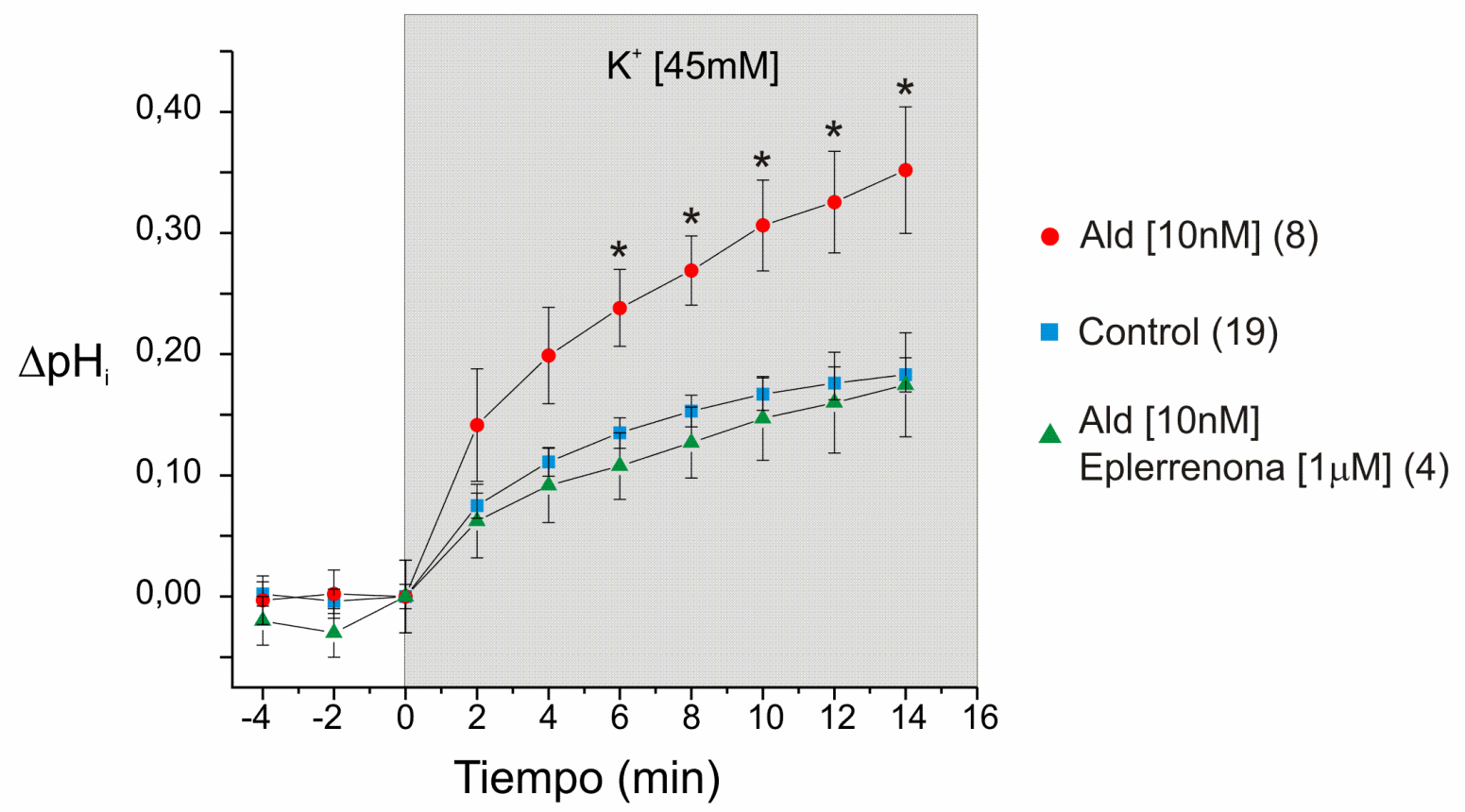

Figura III.5: Efecto de la aldosterona sobre la isoforma electrogenica NBCe1. Se observan los trazos promedios de la despolarización por alto $\mathrm{K}^{+}$. En presencia de aldosterona el incremento de $\mathrm{pH}_{\mathrm{i}}$ es significativamente mayor, efecto que es totalmente inhibido por la presencia del bloqueante del receptor de miralocorticoide (MR). Entre paréntesis se detallan el número de experimentos realizados. ( $* p<0.05$, respecto al control). 


\section{III.8 La aldosterona estimula al NBC por un mecanismo no genómico e independiente de CaMKII}

La aldosterona ha sido descripta profundamente como una hormona que provoca cambios en la expresión de transportadores y canales principalmente en riñón, al unirse al MR el cual actúa como un factor de transcripción. Además, se ha demostrado que la aldosterona es capaz de incrementar la expresión de genes tempranos, entre ellos el SGK1 (Quinasa inducida por Suero/Glucocorticoide) cuya expresión es detectada a los 15-30 minutos [116].

Si bien, nuestros experimentos muestran un efecto de la aldosterona sobre el NBC con una preincubación de 10 min con Ald 10nM, quisimos asegurarnos de que el efecto encontrado se debía a un mecanismo no genómico. Para ello volvimos a realizar los pulsos de $\mathrm{NH}_{4}^{+}$en presencia y ausencia de Ald 10nM pero con cicloheximida, un inhibidor de la síntesis proteica. Como podemos observar en la figura III.6, la activación del NBC por la aldosterona no fue afectada por la presencia de cicloheximida (\% del $\Delta \mathrm{J}_{H}$ : Control $100 \pm 7, n=5$; Ald $145 \pm 11, n=8$; cicloheximida $136 \pm 3, n=4$ ), demostrando que dicha activación se debe a un mecanismo rápido, no genómico.

El grupo de Anderson [99] ha propuesto que todos los efectos deletéreos que posee la aldosterona sobre el corazón son a través de la activación de la CaMKII. La presencia del inhibidor selectivo de la CaMKII, el KN93 no logró inhibir significativamente el efecto de la aldosterona sobre el NBC, demostrando que al menos en nuestro sistema la vía de señalización por la cual la aldosterona activa al NBC es independiente de CaMKII. (\% del $\Delta \mathrm{J}_{\mathrm{H}}$ : Control $100 \pm 7$, $n=5 ;$ Ald $145 \pm 11, n=8 ;$ KN93 $163 \pm 17, n=6)$. 


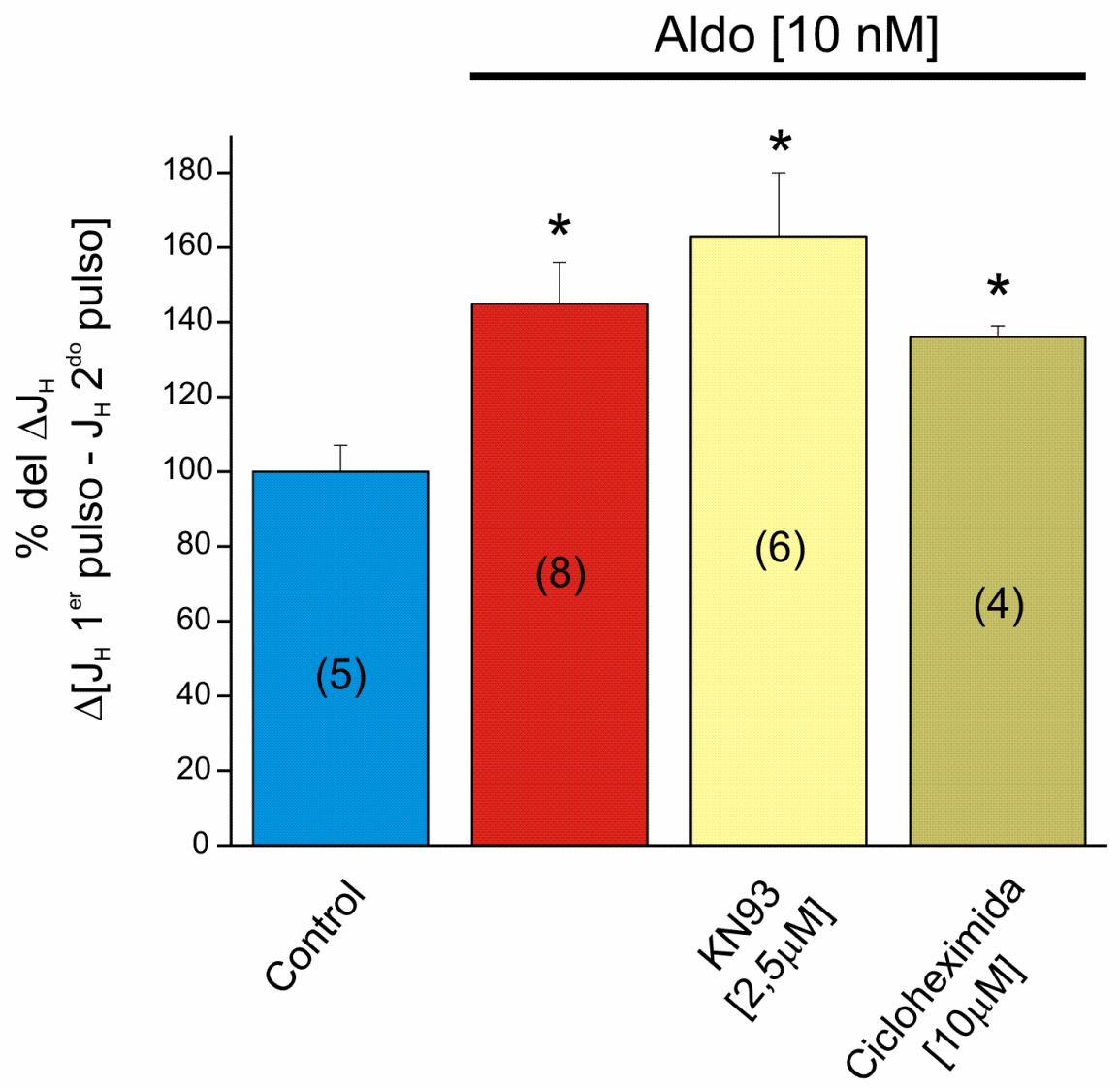

Figura III.6: La aldosterona estimula al NBC por un efecto no genómico e independiente de CaMKII. Se muestran los datos promedios del \% del $\Delta \mathrm{J}_{H}\left(\mathrm{~J}_{H}\right.$ del 2 do pulso $-\mathrm{J}_{H}$ 1er pulso). La presencia de KN93 0 cicloheximida no modificó el efecto que posee la aldosterona sobre el NBC cardíaco. Entre paréntesis se detallan el número de experimentos realizados. $\left({ }^{*} p<0.05\right.$, con respecto al control).

\section{III.9 Las especies reactivas del oxígeno (ERO) como segundos mensajeros del efecto de la aldosterona sobre el NBC}

Las especies reactivas del oxígeno (ERO) juegan un importante papel en la fisiología celular. Mientras que grandes concentraciones son perjudiciales, e inclusive pueden provocar necrosis o apoptosis, pequeñas concentraciones son fundamentales en las vías fisiológicas de señalización intracelular [117]. 
Nuestro laboratorio ha mostrado que las ERO están implicadas en la activación del NHE1 por la aldosterona [96]. Además, demostramos la participación de las ERO en el aumento de la actividad del NBC por la Angll 100nM [34].

Por estos motivos decidimos estudiar la participación de ERO en el efecto de la aldosterona sobre el NBC. Para ello realizamos pulsos de $\mathrm{NH}_{4}{ }^{+}$utilizando un secuestrador de ERO, el mercapto-propionil-glicina (MPG) [2 mM] y el inhibidor de la NADPH oxidasa (NOX), apocinina [300 $\mu \mathrm{M}$ ]. Como observamos en la figura III.7 el efecto de la aldosterona fue totalmente eliminado mediante la adición del secuestrador de ERO o el inhibidor de la NOX (\% del $\Delta \mathrm{J}_{\mathrm{H}}$ : Control $100 \pm 7, \mathrm{n}=5$; Ald $145 \pm 11, \mathrm{n}=8$; MPG $98 \pm 12, \mathrm{n}=4$; Apo $94 \pm 6, \mathrm{n}=4$ ).

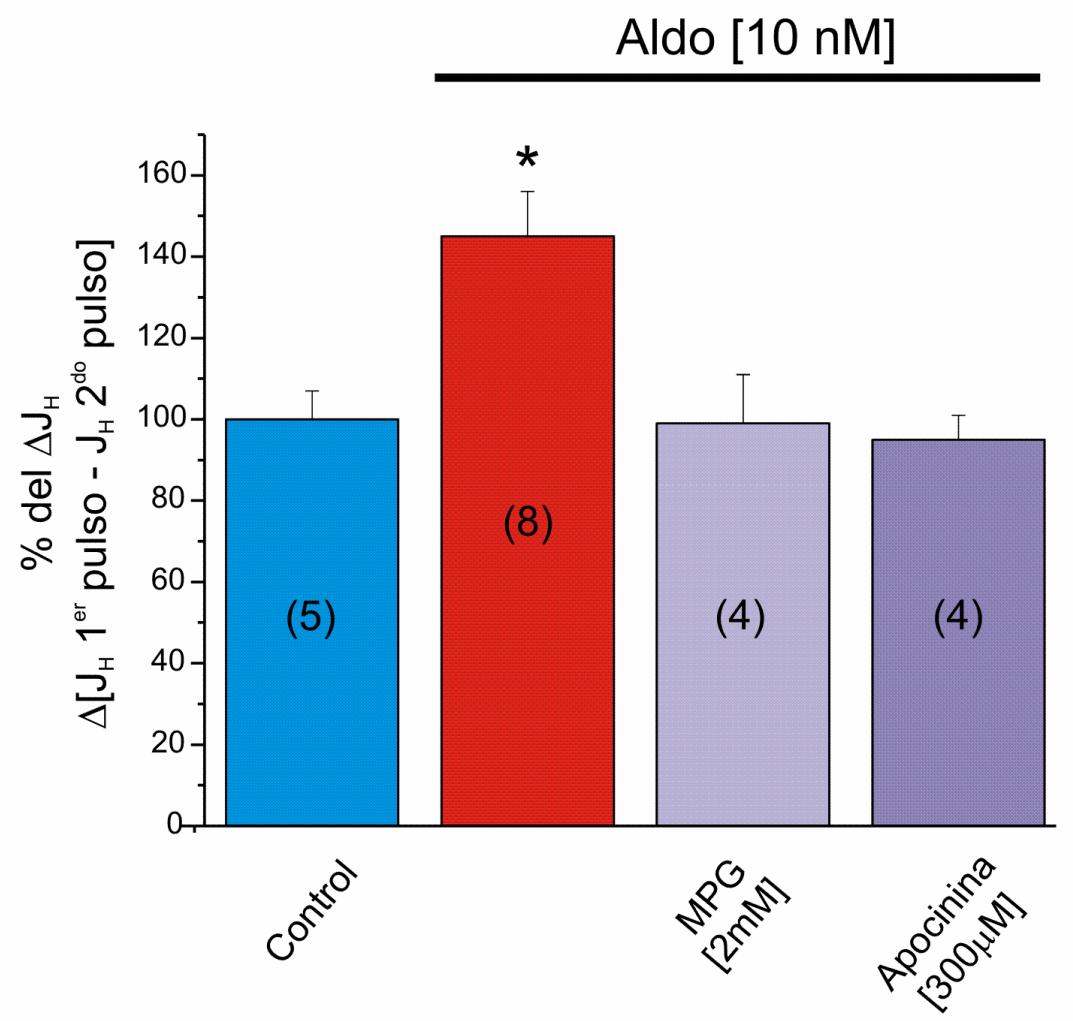

Figura III.7: Participación de las ERO en el efecto de la Aldosterona sobre el NBC cardíaco. Se muestran los datos promedios del $\%$ del $\Delta \mathrm{J}_{H}\left(\mathrm{~J}_{\mathrm{H}}\right.$ del 2 do pulso $-\mathrm{J}_{\mathrm{H}}$ 1er pulso). El efecto de la aldosterona [10nM] fue totalmente evitado por la presencia de MPG y apocinina. Entre paréntesis se detallan el número de experimentos realizados. $\left({ }^{*} p<0.05\right)$. 
Estudiamos la participación de las ERO sobre el efecto que posee la aldosterona sobre el NBCe1 a través de la despolarización por alto $\mathrm{K}^{+}$. El incremento de $\mathrm{pH}$ en presencia de aldosterona fue abolido por la presencia de MPG y apocinina, evidenciando la participación de ERO en las vías de señalización gatilladas por la aldosterona, tal como se encontró en el pulso de $\mathrm{NH}_{4}{ }^{+}\left(\Delta \mathrm{pH}_{\mathrm{i}}\right.$ a los 14 min: control $0.18 \pm 0.014, \mathrm{n}=19 ;$ Ald $0.35 \pm 0.05, \mathrm{n}=8 ;$ Ald $+\mathrm{MPG} 0.18 \pm$ 0.01, n=3; Ald + Apo $0.135 \pm 0.014, n=3$ ) (figura III.8.).

Con estos resultados podemos inferir que las especies reactivas del $\mathrm{O}_{2}$ originadas por la NADPH oxidasa se encuentran formando parte de la vía de señalización por la cual la aldosterona activa al contransporte NBC.

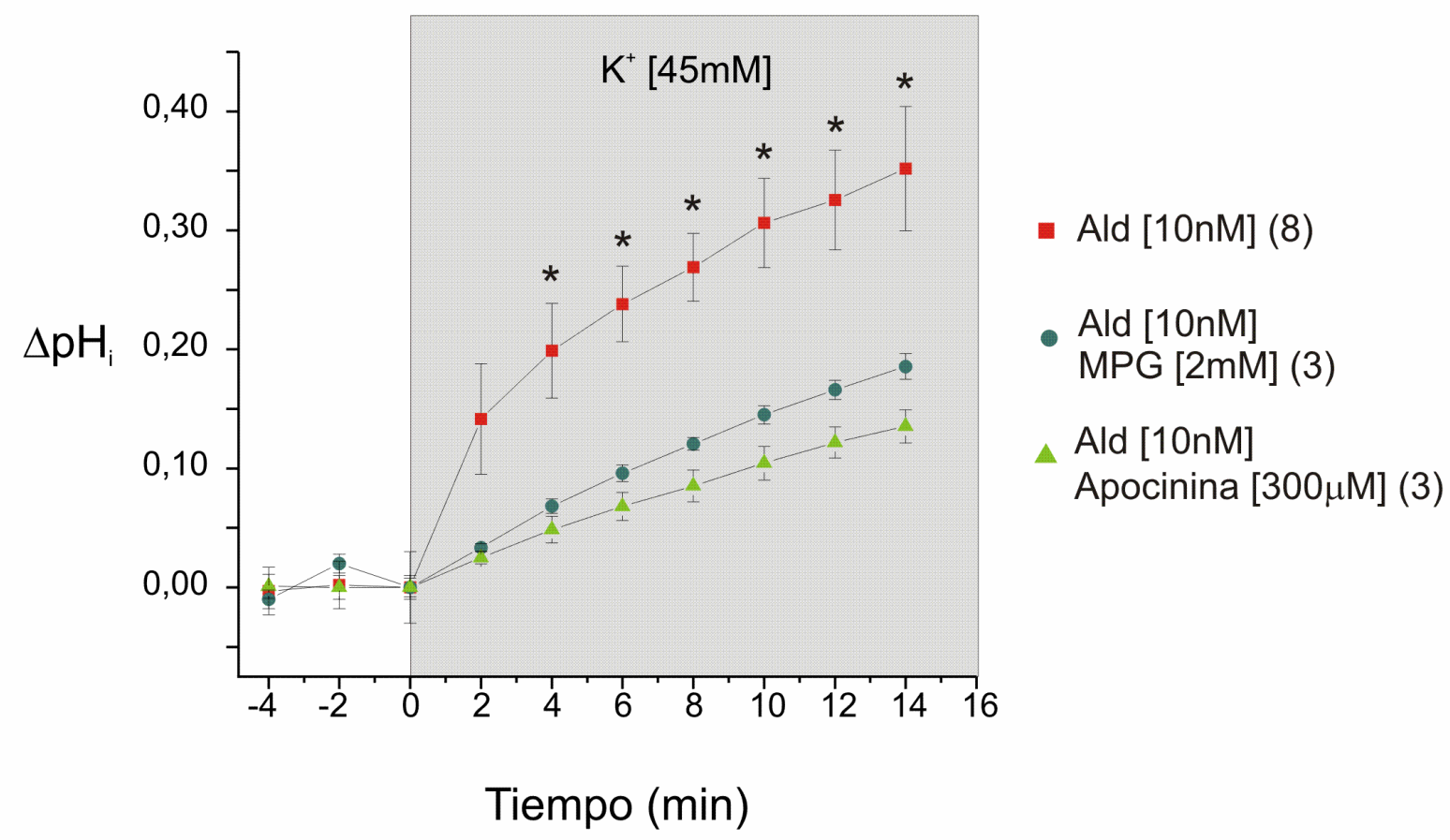

Figura III.8: Participación de las ERO en el efecto de la Aldosterona sobre el NBCe1. Se observan los trazos promedios de la despolarización por alto $\mathrm{K}^{+}$. La presencia de aldosterona [10nM] provoca un aumento en la actividad del NBCe1. La preincubación con MPG o Apocinina inhibe totalmente el efecto de la aldosterona. Estos resultados indican que las ERO son necesarias en la vía de senalización gatilladas por la aldosterona. Entre paréntesis se detallan el número de experimentos realizados. $\left({ }^{*} p<0.05\right)$. 


\section{III.10 Participación del receptor GPR30}

Como se ha descripto el GPR30 es un receptor de la familia asociados a proteína G, uno de cuyos posible ligandos es la aldosterona. Estudiamos en la vía de activación del NBC cardíaco por la aldosterona la posible participación del receptor GPR30 como el encargado de mediar los efectos rápidos.

Para ello se utilizó un agonista (G1) y un antagonista (G15) sintético del GPR30. Se realizaron dobles pulsos de $\mathrm{NH}_{4}{ }^{+}$en presencia de $\mathrm{G} 1$ (figura III.9). Como podemos observar en la figura III.9.B. el G1 fue capaz de aumentar la velocidad de recuperación del $\mathrm{pH}_{\mathrm{i}}$ en aproximadamente un $80 \%$, este efecto fue totalmente inhibido en presencia de $\mathrm{G} 15$ (\% del $\Delta \mathrm{J}_{\mathrm{H}}$ : Control $100 \pm 7, n=5 ; G 1187 \pm 11, n=7 ; G 1+G 15118 \pm 2.4, n=5)$ demostrando que dicho efecto es mediado por GPR30.

Si bien es ampliamente aceptado que la eplerrenona y la espironolactona son inhibidores específicos contra el receptor de mineralocorticoide, Gross et al. demostraron que dichos inhibidores eran capaces de bloquear con menor afinidad al receptor GPR30 [105]. Para evaluar dicha posibilidad se realizaron pulsos de amonio en presencia de G1 y con los inhibidores del MR. Consistentemente a lo demostrado por Gross, hallamos que los efectos mediados por GPR30 eran bloqueados por los inhibidores del MR (figura III.9.B.) (\% del $\Delta \mathrm{J}_{\mathrm{H}}$ : G1 $187 \pm 7, n=7$; Eple $114 \pm 9, n=6$; Espiro, $120 \pm 5, n=4)$.

Las ERO también forman parte de la vía de señalización mediada por GPR30. Ya que en presencia del secuestrador de ERO, MPG, pudimos inhibir totalmente el efecto mediado por G1 (\% del $\Delta \mathrm{J}_{H}: \mathrm{G} 1187 \pm 7, \mathrm{n}=7$; MPG, $\left.93 \pm 10, \mathrm{n}=4\right)$. 
A

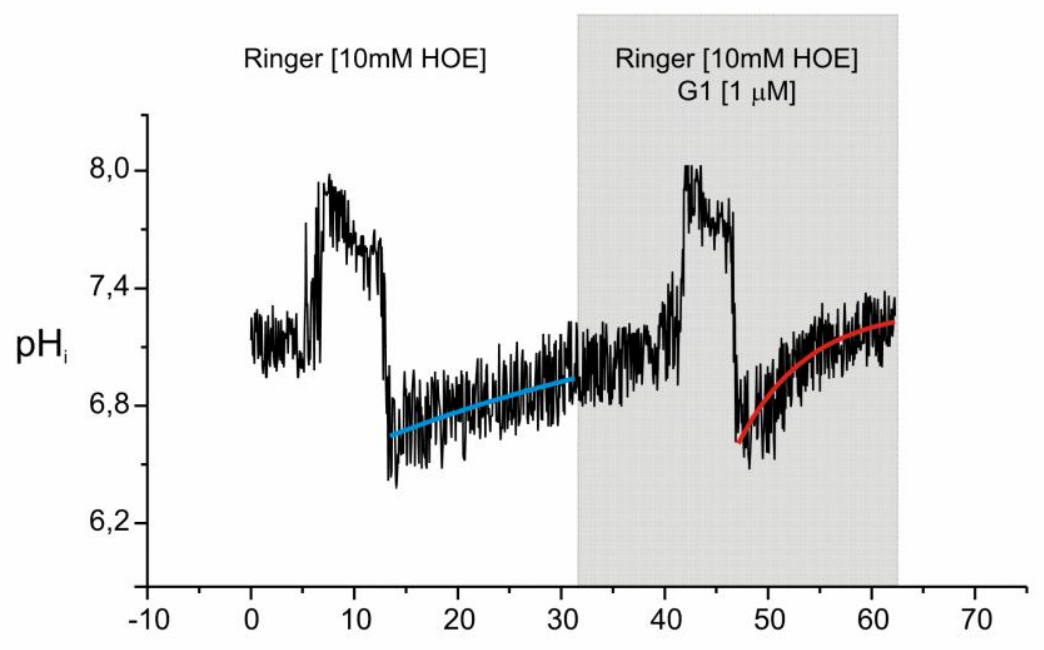

B

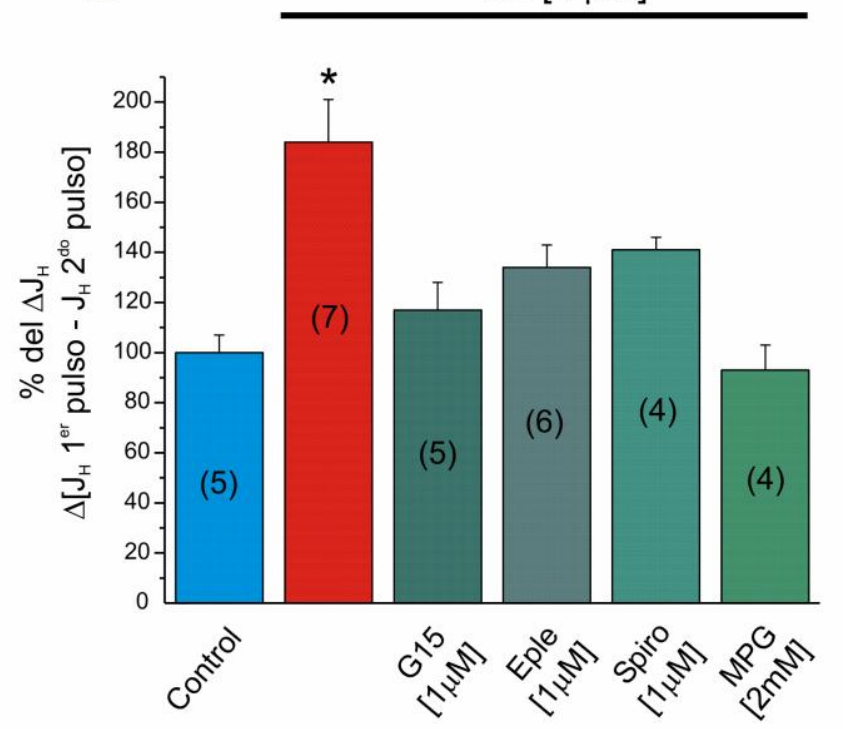

Figura III.9. Participacion del GPR30 en la via de señalizacion mediada por Ald. Se observa los trazos representativos del doble pulso de $\mathrm{NH}_{4}{ }^{+}$control y en presencia de $\mathrm{G} 1[1 \mu \mathrm{M}]$. Todas las drogas tuvieron una incubación previa de 10 min antes del pulso de $\mathrm{NH}_{4}{ }^{+}$. B. Barras promedio del \% del $\Delta \mathrm{J}_{\mathrm{H}}\left(\mathrm{J}_{\mathrm{H}}\right.$ del 2 do pulso $-J_{H} 1$ er pulso). Se observa el incremento de la actividad del NBC en presencia de G1 y su inhibición por la presencia del antagonista del GPR30 (G15), los inhibidores del MR (espironolactona y eplerrenona) y el secuestrador de ERO (MPG). Entre paréntesis se detallan el número de experimentos realizados. $\left({ }^{*} p<0.05\right)$.

Además, encontramos que la preincubación de los miocitos con G15 fue capaz de prevenir la activación del NBC por aldosterona (figura III.10), confirmando la participación del GPR30 en la vía de señalización de la hormona. (\% del $\Delta_{\mathrm{H}}$ : Control $100 \pm 7, \mathrm{n}=5$; Ald $145 \pm 11$, $\mathrm{n}=8 ; \mathrm{Ald}+\mathrm{G} 1589 \pm 2.5, \mathrm{n}=3$ )

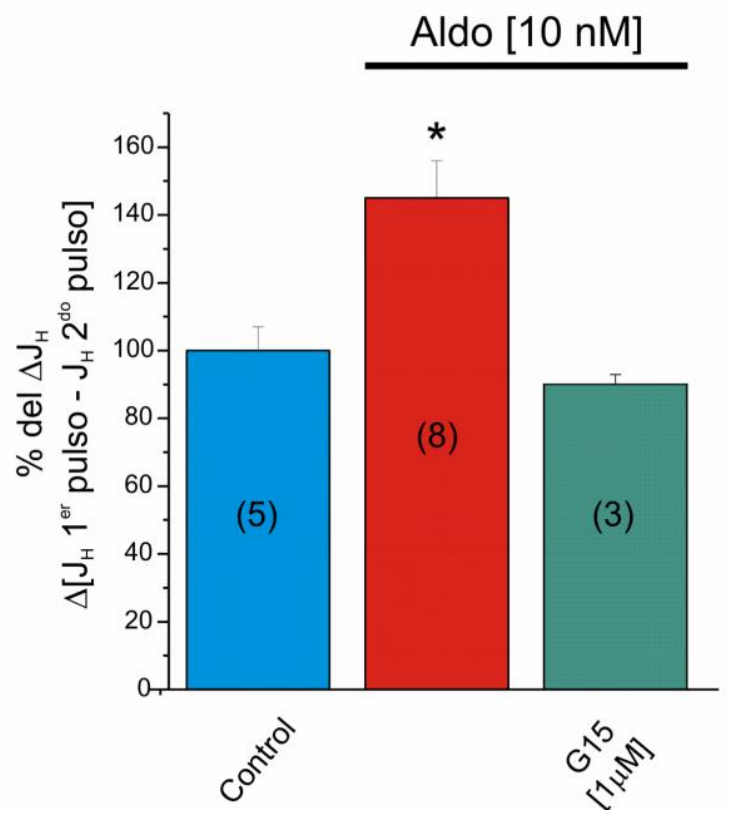

Figura III.10. La aldosterona ejerce su acción a través del receptor GPR30. Datos promedio del \% del $\Delta \mathrm{J}_{H}\left(\mathrm{~J}_{H}\right.$ del 2 do pulso - $J_{H}$ 1er pulso). La acción de la aldosterona es inhibida totalmente por la incubación con el antagonista selectivo del GPR30. Estos resultados demuestran que la aldosterona a través del receptor GPR30 gatilla una cascada de señalización incrementando el transporte mediado por NBC. Entre paréntesis se detallan el número de experimentos realizados. $\left({ }^{*} p<0.05\right)$. 
Evaluamos la actividad del NBCe1 a través de los pulsos de $\mathrm{K}^{+}$. Como podemos observar en los trazos promedio de la figura III.11 demostramos que el bloqueante específico del receptor GPR30, G15 [1 $1 \mu \mathrm{M}]$ es capaz de impedir el incremento del la actividad del NBCe1 causada por la aldosterona. Estos resultados demuestran que la aldosterona al unirse al receptor GPR30 ejerce su acción estimulatoria sobre el NBCe1.

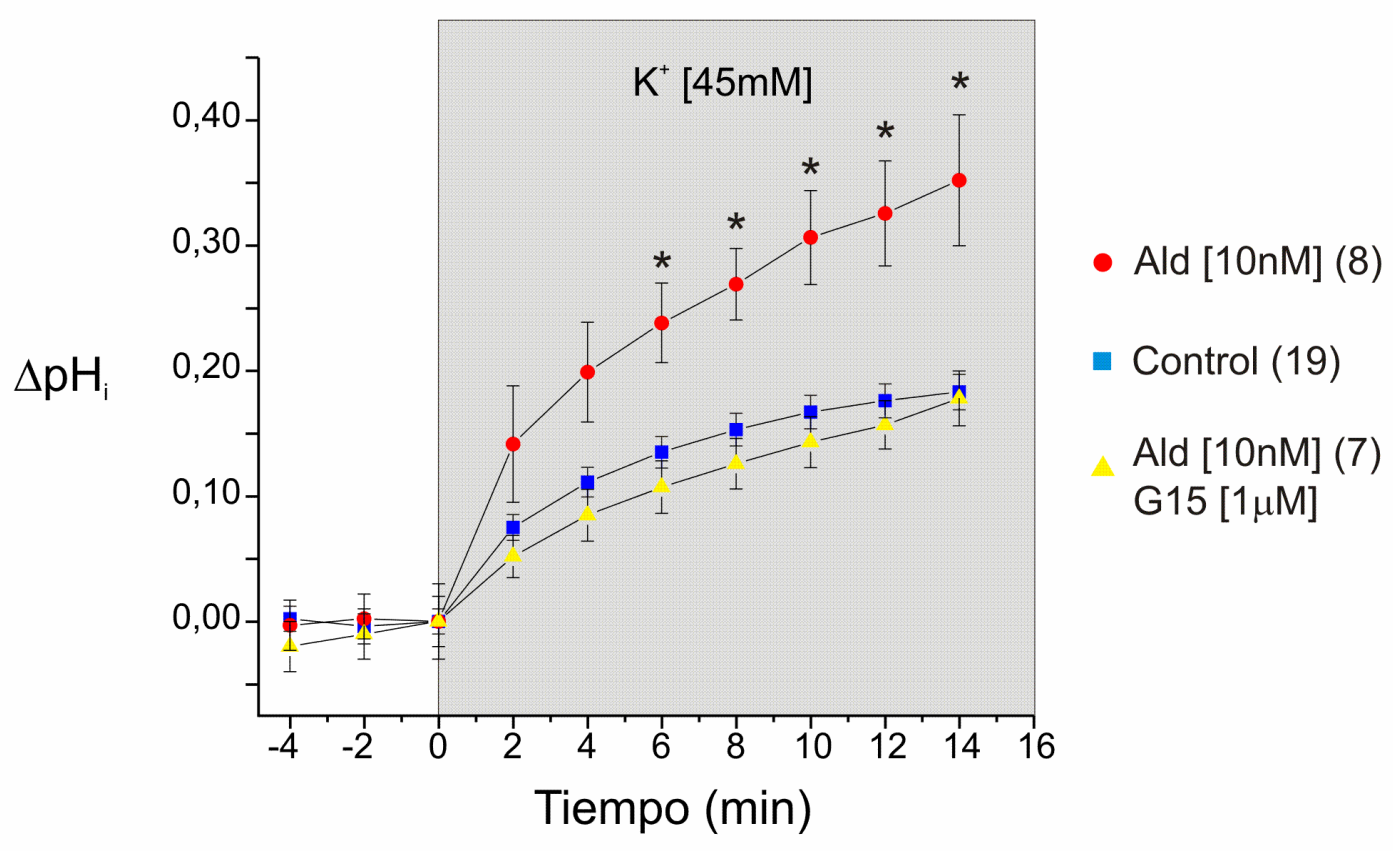

Figura III.11. La aldosterona a traves del GPR30 incrementa la actividad del NBCe1. Se observan los trazos promedios de la despolarización por alto $\mathrm{K}^{+}$. La presencia de $\mathrm{G} 15$ fue capaz de evitar la mayor actividad del NBCe1 sugiriendo al GPR30 como el receptor responsable de gatillar los efectos de la aldosterona. Entre paréntesis se detallan el número de experimentos realizados. $\left({ }^{*} p<0.05\right)$. 


\section{III.11 Discusión}

En la segunda parte de esta tesis doctoral, estudiamos la regulación del NBC cardíaco por la aldosterona. Basándonos en los datos funcionales realizados en miocitos ventriculares de rata confirmamos la activación del cotransporte $\mathrm{Na}^{+} / \mathrm{HCO}_{3}{ }^{-}$cardíaco por la aldosterona.

Además, se demostró que las especies reactivas del $\mathrm{O}_{2}$ se encuentran formando parte de la vía de señalización gatillada por la aldosterona.

Describimos funcionalmente que la activación del NBC por la presencia de la hormona esteroidea es independiente de la quinasa dependiente de $\mathrm{Ca}^{2+}$ y calmodulina (CaMKII) así como dicha activación es a través de un mecanismo no genómico.

A través del protocolo experimental denominado pulsos de $\mathrm{K}^{+}$pudimos demostrar que la isoforma electrogénica NBCe1 es activada por la aldosterona [10nM]. Sin embargo no pudimos disecar la actividad de la isoforma electroneutra NBCn1, pudiendo o no ser afectada su actividad por la aldosterona. Ya que si bien se obtuvo una mayor actividad del NBC total, ésta podría deberse únicamente a la actividad del NBCe1.

Finalmente, propusimos que los efectos rápidos de la aldosterona sobre el NBC cardíaco son a través del receptor de GPR30.

La activación del cotransporte $\mathrm{Na}^{+} / \mathrm{HCO}_{3}{ }^{-}$cardíaco por la aldosterona es un hallazgo totalmente novedoso, hasta el momento nunca descripto. Ha sido demostrado que la aldosterona es un potente activador de la NADPH oxidasa aumentando la concentración de ERO. Los estudios que implican a las ERO como participantes en las vías de señalización intracelular han crecido notablemente alejando aquel concepto que únicamente provocan muerte celular por oxidación. Recientemente nuestro laboratorio ha demostrado que las ERO inducidas por Ang II son capaces de incrementar el transporte mediado por el NBC total. En esa oportunidad se describió que la Ang II provoca la activación del NBCn1 mediado por las ERO, mientras que el NBCe1 se encontraba inhibido por la activación de la quinasa p38. Sin embargo, en el presente trabajo se describe un aumento en la actividad del NBC total, como así también 
un aumento en la actividad del NBCe1, mediado por las ERO. Esta discrepancia se podría explicar ya que la Ang II además de incrementar la producción de ERO activa la vía de la p38, la cual inhibe al NBCe1. Esta inhibición subsiste independientemente a la concentración de ERO. En el caso de la aldosterona, se podría pensar que no existe una activación de la p38, por lo tanto las ERO incrementan la actividad del NBCe1. Futuros experimentos utilizando inhibidores de la p38 podrían esclarecer esta controversia.

El hecho de que la aldosterona incremente la actividad del NBC en pocos minutos y que dicho incremento no se evite por la administración de bloqueantes de la traducción (cicloheximida) habla claramente de un mecanismo no genómico. Se ha propuesto que los efectos genómicos y no genómicos de la aldosterona son a través del receptor de mineralocorticoides (MR). El MR se activa con mineralocorticoides como la aldosterona, la desoxicorticoesterona, así como también con los glucocorticoides, cortisol y cortisona. La aldosterona al unirse al MR provoca la homodimerización del receptor y su posterior translocación al núcleo. Los elementos de respuesta hormonal son secuencias de nucleótidos presentes en el promotor de algunos genes que consta de un par de repeticiones invertidas separadas por otros tres nucleótidos, lo que indica que el receptor se une en forma de dímero. Conociendo el mecanismo de acción del receptor $M R$, hace difícil pensar al complejo aldosterona-MR como el encargado de iniciar la vía no genómica como es aceptado hasta el día de hoy. En el presente trabajo de tesis proponemos que la aldosterona al unirse al receptor GPR30 desencadena una activación de la vía intracelular no genómica.

En este trabajo se utilizaron dos inhibidores del MR, la eplerrenona y la espironolactona. Recientemente la especificidad de estos inhibidores del MR ha sido fuertemente cuestionada. Gross et al. propusieron a la eplerrenona como un antagonista parcial del GPR30. Este concepto fue criticado ya que farmacológicamente si un antagonista es parcial también debería ser un agonista parcial lo que no fue demostrado por Gross. Otra posibilidad es que en realidad la eplerrenona es un antagonista del GPR30 pero con una mayor $K_{i}$ siendo necesarias concentraciones superiores para su total inhibición. De todos modos estas posibilidades deberán ser corroboradas empíricamente. 
Es conocido el incremento en las concentraciones intracelulares de $\mathrm{Na}^{+} \mathrm{y} \mathrm{Ca}^{2+}$ en la hipertrofia y en la insuficiencia cardíaca [118-122]. La activación del NBC por la aldosterona podría explicar al menos en parte el aumento de la concentración de estos iones, ya que el aumento de $\mathrm{Na}^{+}$conduce a un consecuente aumento de $\mathrm{Ca}^{2+}$ por la activación del modo reverso del NCX.

La activación del NBC por la aldosterona podría explicar al menos en parte las implicancias fisiopatológicas que posee esta hormona en el músculo cardíaco.

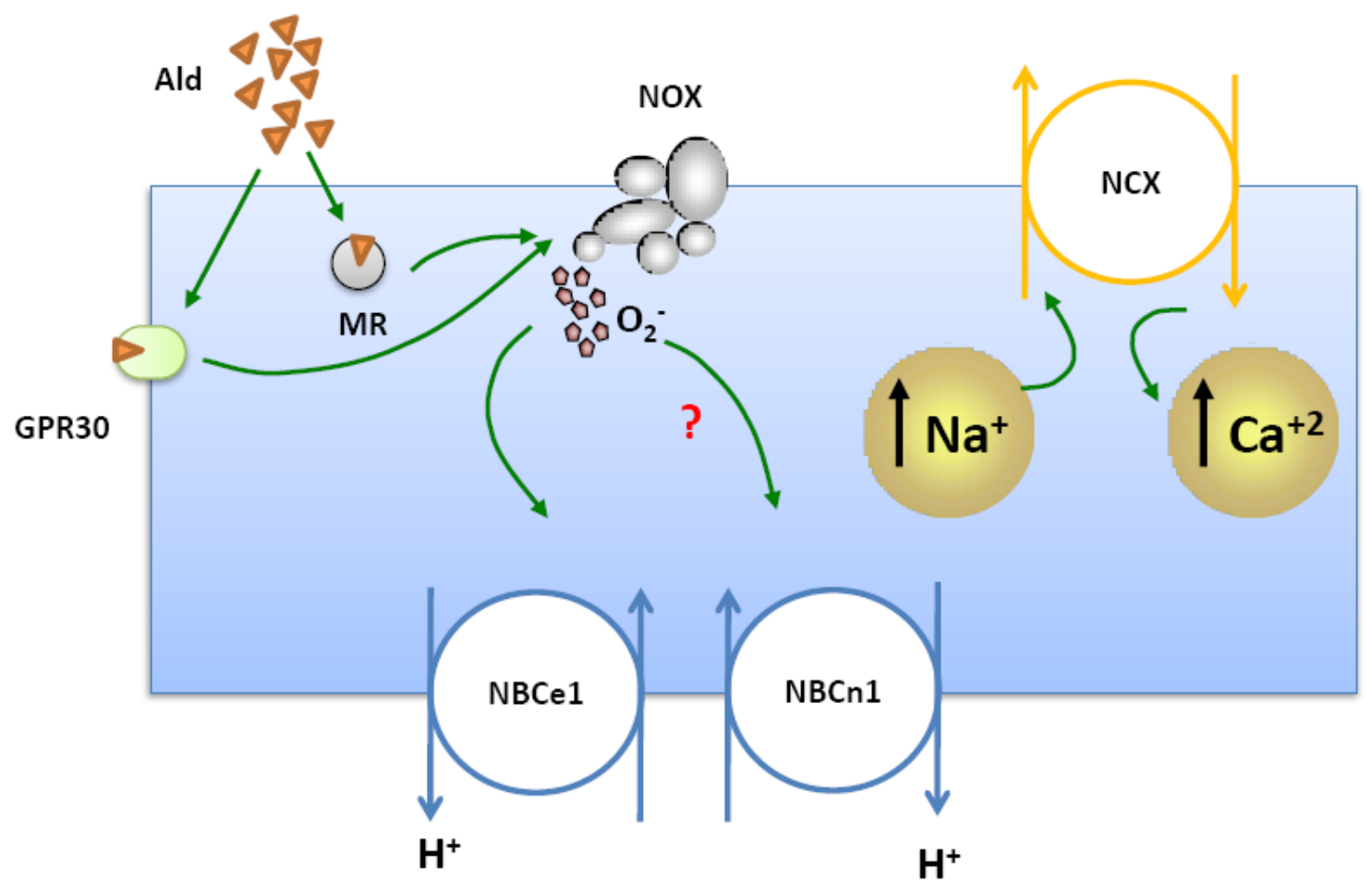

Figura III.12. Esquema de la vía de señalización por la cual la aldosterona activa al NBC. La aldosterona a través de su clásico receptor MR o del receptor GPR30 incrementa la actividad de la NOX aumentando la producción de las especies reactivas del $\mathrm{O}_{2}$, las cuales a través de una mecanismo aún no dilucidado activa el transporte mediado por NBC. Al aumentar la concentración de $\mathrm{Na}^{+}$provoca que la fuerza impulsora del NCX disminuya, reduciendo la salida del $\mathrm{Ca}^{2+}$. Inclusive si la concentración de $\mathrm{Na}^{+}$aumenta significativamente puede revertir la dirección del $\mathrm{NCX}$, transportando $\mathrm{Ca}^{2+}$ al interior y sacando $\mathrm{Na}^{+}$. Esto resulta en un aumento del $\mathrm{Ca}^{2+}$ citosólico el cual es el precursor de señales hipertróficas y de arritmias. 


\section{IV}

\section{Regulación del cotransporte NBCn1 por la presión de $\mathrm{CO}_{2}$}

\section{IV.1 Introducción}

El riñón mantiene el balance ácido-base gracias a la capacidad de secretar $\mathrm{H}^{+}$y por la reabsorción de $\mathrm{HCO}_{3}{ }^{-}$. Las células del túbulo proximal reabsorben $\mathrm{HCO}_{3}{ }^{-}$debido a la expresión del NHE3 que se encuentra localizado en la zona apical de la célula y la expresión basolateral del cotransportador electrogénico $\mathrm{Na}^{+} / \mathrm{HCO}_{3}{ }^{-}$de riñón (kNBC1). $(8,17,30,31)$. Se han descripto otros miembros de la familia SLC4 los cuales jugarían un rol muy importante en el transporte acido-base y/o en el mantenimiento del pH intracelular. [29, 123-127].

El NBC electroneutro (NBCn1) ha sido clonado por primera vez en células del músculo liso vascular [29] y su expresión ha sido descripta en células de túbulo distal del riñón [128]. Consistentemente, se demostró la existencia de un transportador dependiente de $\mathrm{Na}^{+}$en células aisladas del túbulo distal, el cual es responsable de la recuperación del $\mathrm{pH}_{\mathrm{i}}$ luego de una acidosis en presencia de $\mathrm{HCO}_{3}{ }^{-}$en el medio extracelular [129]. Además, fue descripta su localización tisular mediante ensayos de inmunofluorescencia [129]. 
La acidosis metabólica crónica incrementa la expresión del cotransportador electroneutro NBCn1 en el riñón de rata, manteniendo inalterado la expresión del cotransportador electrogénico NBCe1. Además, se ha descripto un aumento en la expresión del NBCn1 en células de la médula ascendente expuestas a condiciones ácidas, las cuales modificaron la concentraciones de $\mathrm{HCO}_{3}{ }^{-}$del medio extracelular [130].

En este capítulo se estudiará la regulación por $\mathrm{CO}_{2}$ de la expresión del NBCn1 en células embrionarias de riñón humano (HEK293) y cómo se encuentra alterada su función. Adicionalmente describiremos la contribución que posee el NBCn1 en la regulación del $\mathrm{pH}_{\mathrm{i}}$ en células HEK luego de una acidificación intracelular. 


\section{IV.2 Objetivo general 3}

En la tercera parte de la presente tesis doctoral se estudió la regulación del NBC en células HEK293 por el incremento de la presión de $\mathrm{CO}_{2}$.

\section{Objetivos específicos}

- Demostrar la presencia endógena de un transporte dependiente de $\mathrm{Na}^{+}$y $\mathrm{HCO}_{3}{ }^{-}$en células HEK293.

- Describir la isoforma del NBC responsable del transporte endógeno en células HEK293.

- Evaluar la expresión y correlacionarla con la función del NBC en células HEK293 luego de 24 horas de cultivo al $5 \%, 10 \%$ y $15 \%$ de $\mathrm{CO}_{2}$. 


\section{IV.3 Regulación del pH intracelular en células HEK293}

Células HEK293 cargadas con el indicador fluorescente sensible a $\mathrm{pH}_{\mathrm{i}}, \mathrm{BCECF-AM}$, fueron sometidas a un pulso de $\mathrm{NH}_{4}{ }^{+}$con el fin de lograr una acidificación intracelular. Se analizó la velocidad inicial de recuperación del $\mathrm{pH}_{\mathrm{i}}$ en un buffer conteniendo $\mathrm{HCO}_{3}{ }^{-}, \mathrm{Na}^{+}$y bloqueantes del intercambiador $\mathrm{Na}^{+} / \mathrm{H}^{+}$. En presencia de los inhibidores del NHE (EIPA, 10-50 $\mu \mathrm{M}$ ), o $1 \mu \mathrm{M}$ de Amiloride, se halló un descenso de $60 \%$ de la velocidad de recuperación del $\mathrm{pH}_{\mathrm{i}}$, evidenciando la existencia de un mecanismo regulador del $\mathrm{pH}_{\mathrm{i}}$ independiente al NHE (figura IV.1. A y B).

A

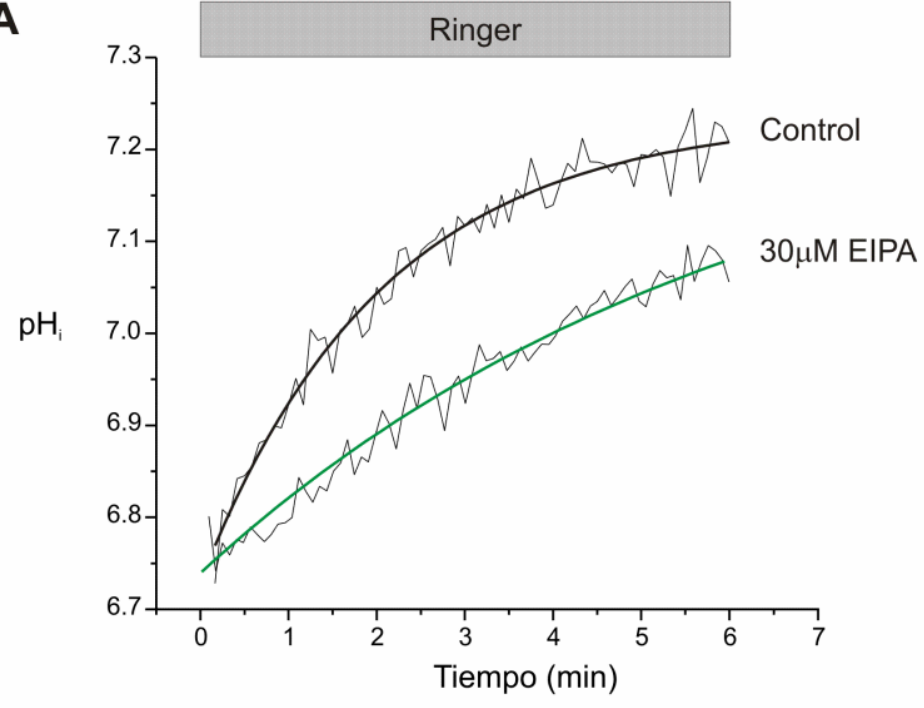

B

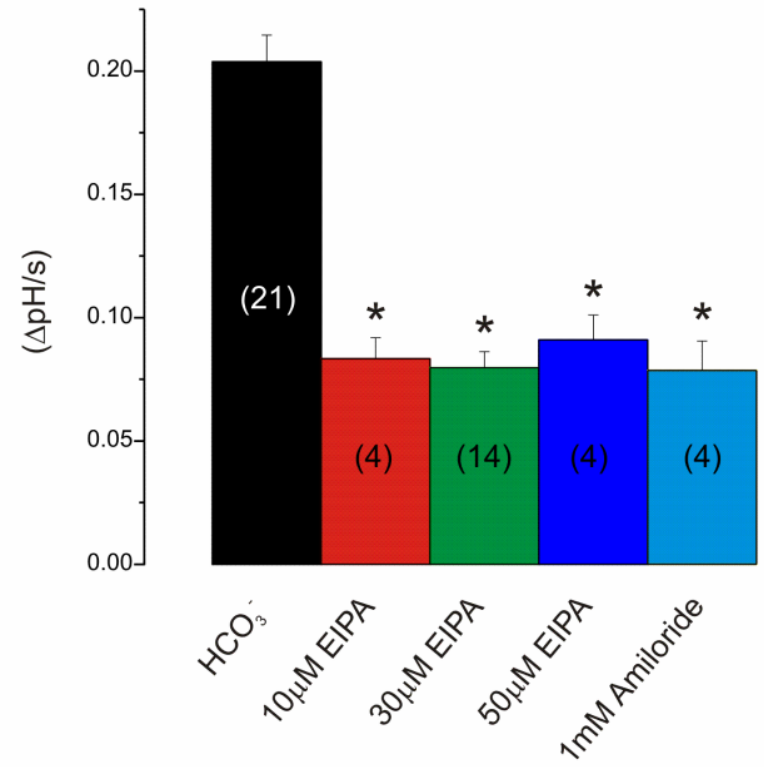

Figura IV.1: Transporte endógeno EIPA-insensible en células HEK293. A. Trazos representativos del $\mathrm{pH}_{\mathrm{i}}$ luego de una acidificación por un pulso de $\mathrm{NH}_{4}{ }^{+}$en condición control con y sin $30 \mu \mathrm{M}$ de EIPA para inhibir al intercambiador $\mathrm{Na}^{+} / \mathrm{H}^{+}$. Existe una recuperación que es insensible a los bloqueantes del NHE demostrando la presencia de otro mecanismo regulador de $\mathrm{pH}_{\mathrm{i}}$. B. Datos promedio de la velocidad inicial de recuperación en condición control y con Amiloride o diferentes concentraciones de EIPA. Entre paréntesis se detallan el número de experimentos realizados. $\left({ }^{*} p<0.05\right)$.

En un buffer sin $\mathrm{HCO}_{3}^{-}$(HBS), $30 \mu \mathrm{M}$ de EIPA anuló totalmente la recuperación del $\mathrm{pH}_{\mathrm{i}}$ luego de la sobrecarga ácida, demostrando que el mecanismo EIPA-insensible es además dependiente $\mathrm{HCO}_{3}^{-}$(figura IV.2. A y B). 
A

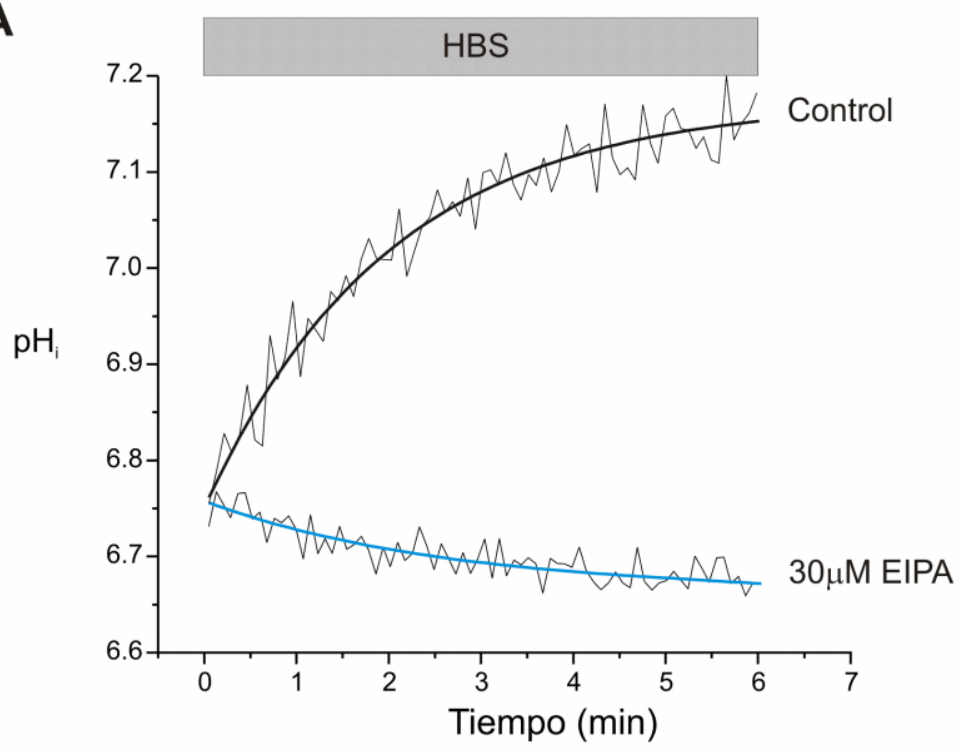

\section{HBS}

B

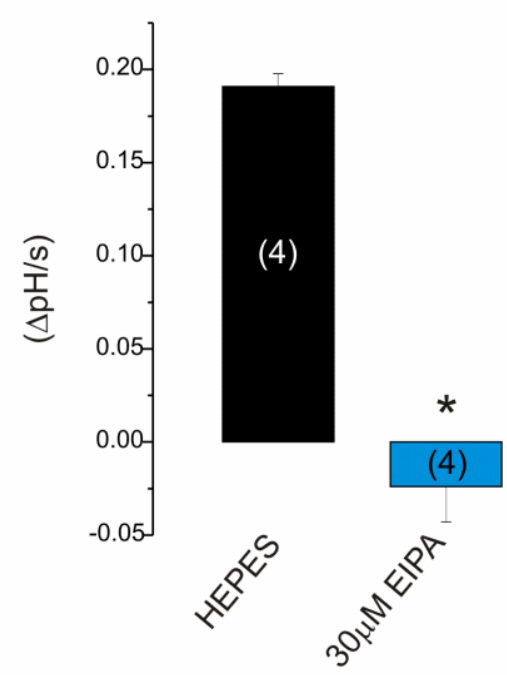

Figura IV.2: El transporte EIPA-insensible es dependiente de $\mathbf{H C O}_{3}{ }^{-}$. A. Trazos representativos del $\mathrm{pH}_{\mathrm{i}}$ luego de una acidificación por un pulso de $\mathrm{NH}_{4}{ }^{+}$sin bicarbonato extracelular (HBS, Hepes Buffer Salino) con y $\sin 30 \mu \mathrm{M}$ de EIPA para bloquear el intercambiador $\mathrm{Na}^{+} / \mathrm{H}^{+}$. En ausencia de $\mathrm{HCO}_{3}{ }^{-}$y con el $\mathrm{NHE}$ inhibido no se evidencia recuperación del $\mathrm{pH}_{\mathrm{i}}$ demostrando necesidad de la presencia de $\mathrm{HCO}_{3}{ }^{-}$ extracelular para el mecanismo regulador del $\mathrm{pH}_{\mathrm{i}}$ EIPA-insensible. B. Datos promedio de la velocidad inicial de recuperación en condición control o en presencia de EIPA. Entre paréntesis se detallan el número de experimentos realizados. ( $\left.{ }^{*} p<0.05\right)$.

Con el fin de estudiar la posible dependencia con el $\mathrm{Na}^{+}$se lo removió totalmente de la solución extracelular reemplazándolo por Colina (ColinaCl, ColinaHCO${ }_{3}$ ). Como se muestra en la figura IV.3 la ausencia de $\mathrm{Na}^{+}$extracelular evita la recuperación del $\mathrm{pH}_{\mathrm{i}}$, demostrando la dependencia del transportador por la concentración de $\mathrm{Na}^{+}$extracelular. Cuando se reemplazó el $\mathrm{Cl}^{-}$por gluconato la recuperación fue mayor inclusive a la condición control. El transporte es independiente de $\mathrm{Cl}^{-}$y además, debido al incremento en la recuperación de la acidosis se podría especular con la existencia de un intercambiador $\mathrm{Cl}^{-} / \mathrm{HCO}_{3}{ }^{-}$(AE) funcionando en su modo reverso. 
A

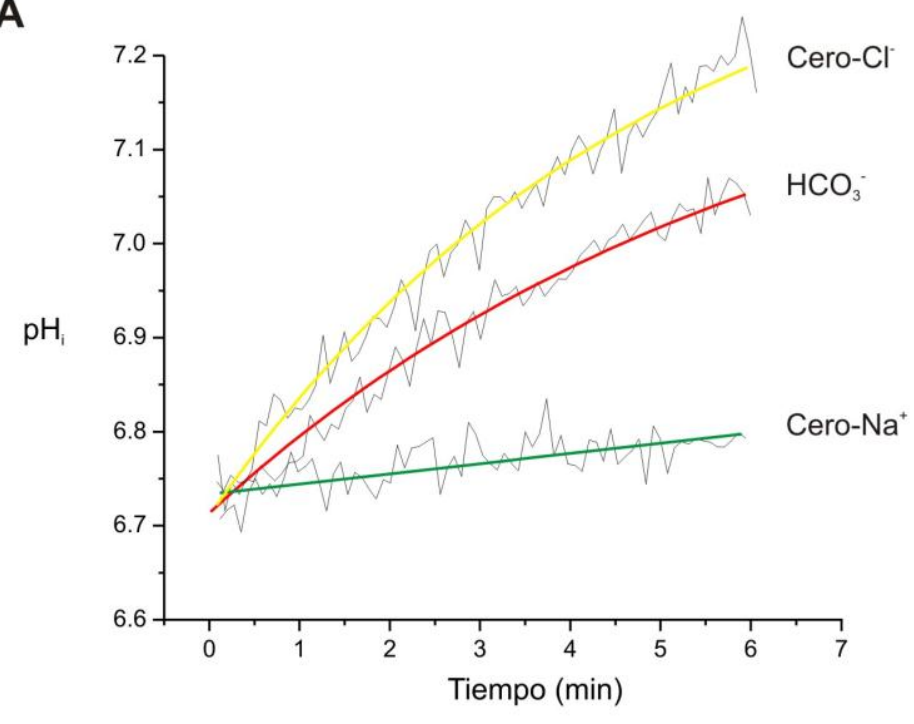

B

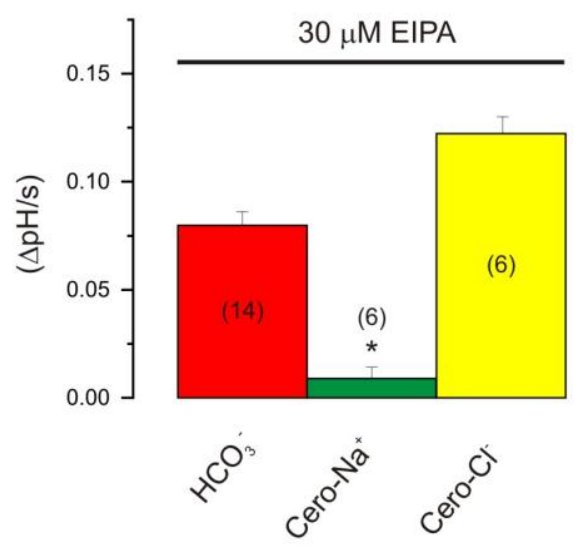

Figura IV.3: Transporte endógeno $\mathrm{Na}^{+}$dependiente y $\mathrm{Cl}^{-}$independiente. A. Trazos representativos de la recuperación del $\mathrm{pH}_{\mathrm{i}}$ luego de un pulso de $\mathrm{NH}_{4}{ }^{+}$en ausencia de $\mathrm{Na}^{+}$o $\mathrm{Cl}^{-}$extracelular, o condición control (Ringer). B. Datos promedio de la velocidad inicial de recuperación para cada una de las 3 condiciones. Entre paréntesis se detallan el número de experimentos realizados. $\left({ }^{*} \mathrm{p}<0.05\right.$, con respecto a $\left.\mathrm{HCO}_{3}{ }^{-}\right)$.

Se comprobó la afinidad que posee el transporte dependiente de $\mathrm{Na}^{+}$y $\mathrm{HCO}_{3}{ }^{-}$con el inhibidor farmacológico específico para el NBC, el S0859 [131, 132]. Se realizó la acidificación intracelular a través del pulso de $\mathrm{NH}_{4}{ }^{+}$en presencia de diferentes concentraciones de $\mathrm{S0859}$ y se determinó la velocidad inicial de recuperación, siempre en presencia de EIPA [30 $\mu \mathrm{M}]$ para descartar la actividad del $\mathrm{Na}^{+} / \mathrm{H}^{+}$.

En la Figura IV.4.A se muestra la recuperación de $\mathrm{pH}_{\mathrm{i}}$ en presencia o ausencia de $\mathrm{S} 0859$ $[60 \mu \mathrm{M}]$ mientras el NHE se encuentra inhibido por EIPA [30 $\mu \mathrm{M}]$. Se realizó la curva dosisrespuesta (Figura IV.4.B) obteniendo para la inhibición del NBCn1 por S0859 un IC50 de $30 \pm 3$ $\mu \mathrm{M}$. Dosis mayores a 60 $\mu \mathrm{M}$ de $\mathrm{S} 0859$ provocó un bloqueo total del transporte. 
A

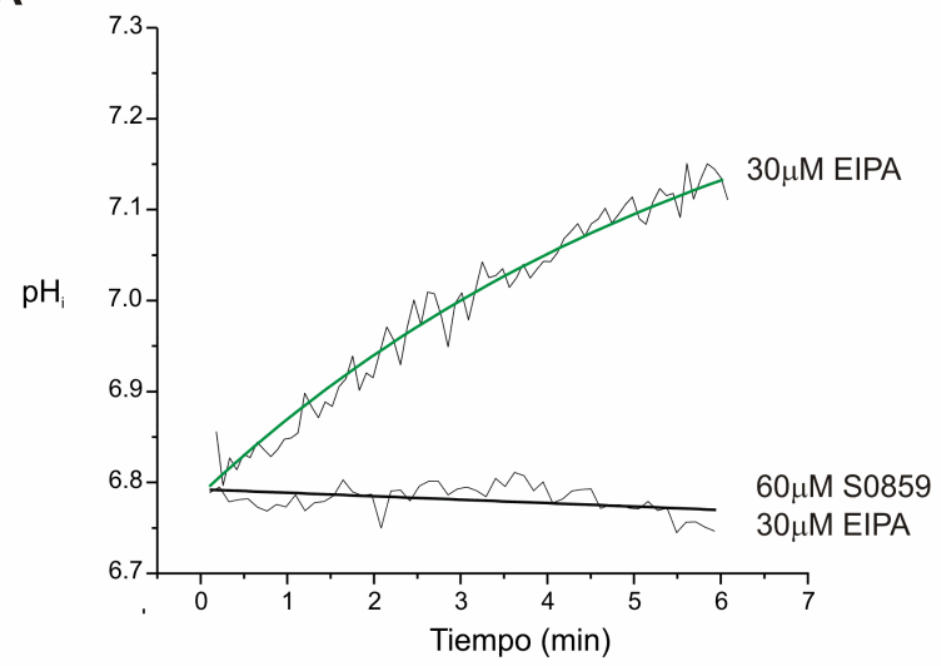

B

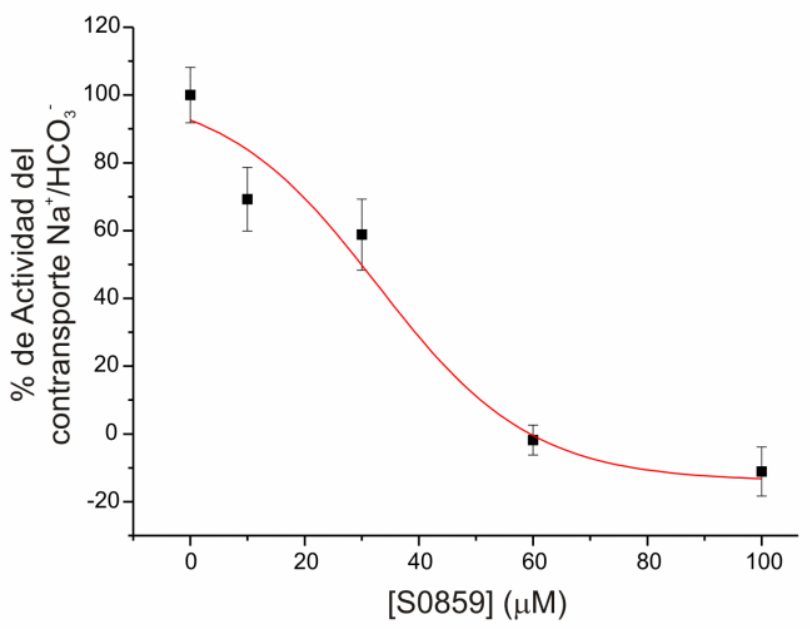

Figura IV.4: Sensibilidad al S0859, inhibidor selectivo del NBC. A. Trazos representativos de la recuperación del $\mathrm{pH}_{\mathrm{i}}$ luego de un pulso de $\mathrm{NH}_{4}{ }^{+}$en un buffer $\mathrm{HCO}_{3}{ }^{-}$en presencia de EIPA con o sin S0859. Se observa la total inhibición del transporte al combinar los inhibidores del NHE (EIPA) y del NBC (S0859). B. Curva dosis respuesta. Se muestran los \% de actividad del NBC para 0, 10, 30, 60 y $100 \mu \mathrm{M}$ de S0859.

Se estudió los niveles de expresión endógena de los contransportadores NBCe1, NBCe2 y NBCn1. En la figura IV.5 se observan los inmunoblots correspondientes a cada uno de los transportadores. Las células además se transfectaron para corroborar que los anticuerpos efectivamente son capaces de detectar a los cotransportadores. Como podemos observar, se halló que en las células HEK293 se expresa endógenamente sólo el cotransportador electroneutro NBCn1. Además, mediante la técnica de RT-PCR se corroboró la presencia del transcripto únicamente correspondiente al NBCn1 (figura IV.6). Los inmunoblots y la RT-PCR indican al NBCn1 como el mecanismo de regulación de $\mathrm{pH}_{\mathrm{i}}$ dependiente de $\mathrm{Na}^{+}$y $\mathrm{HCO}_{3}{ }^{-}$ presente en células HEK293.
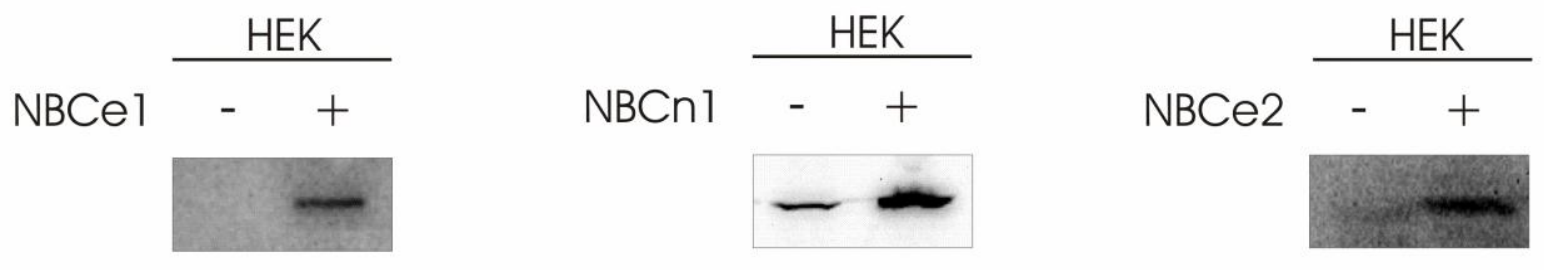

Figura IV.5: Niveles de expresión endógena de los cotransportadores NBCe1, NBCe2 y NBCn1. Inmunoblots de lisados de células HEK293 trasfectadas con NBCe1, NBCe2 y NBCn1 (+) o sin transfectar (expresión endógena) (-). 


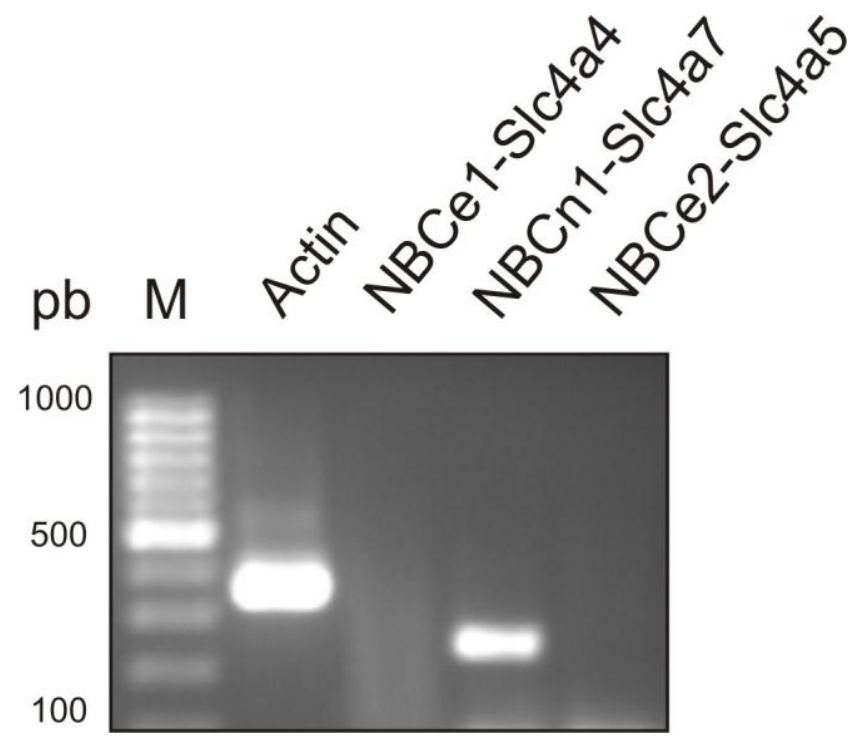

Figura IV.6: Expresión de los transcriptos correspondientes a NBCe1, NBCn1 y NBCe2.

\section{IV.4 Expresión del NBCn1 en células HEK293 expuestas altos niveles de $\mathrm{CO}_{2}$}

Para estudiar como el $\mathrm{CO}_{2}$ podría regular los niveles de expresión del NBCn1, células HEK293 se incubaron en una atmósfera al 5\%, 10\% y $15 \%$ de $\mathrm{CO}_{2}$ durante 24 horas. Mediante la técnica de Western-blot se estudió la expresión utilizando anticuerpos específicos contra NBCn1. El anticuerpo utilizado reconoce al epítope formado por 18 aminoácidos en el extremo carboxilo. Esta región es idéntica en las tres variantes de splicing para el NBCn1 (NBCn1-A, NBCn1-B y NBCn1-C) pero no comparten un grado de homología significativo con las isoformas electrogénicas NBCe1 y NBCe2.

Células HEK293 crecidas 24 horas en una atmósfera al 5\% de $\mathrm{CO}_{2}$ fueron utilizadas como control. La figura IV.7.A. muestra los inmunoblots representativos de las células cuando fueron incubadas al 5\%, $10 \%$ y $15 \%$ de $\mathrm{CO}_{2}$ por 24 horas. El análisis cuantitativo de la expresión de NBCn1 mostró un aumento de 3 veces con respecto al control para aquellas células expuestas al $10 \%$ de $\mathrm{CO}_{2}$, y 7 veces mayor para aquellas expuestas al $15 \%$ de $\mathrm{CO}_{2}$. Además, se estudió el aumento en la expresión de NBCn1 en membrana mediante la técnica de marcación con Biotina 
(ver materiales y métodos). Como era de esperar hubo una correlación positiva entre el aumento de la presión de $\mathrm{CO}_{2}$ y la expresión de $\mathrm{NBCn} 1$ en membrana (figura IV.7.B.).

A
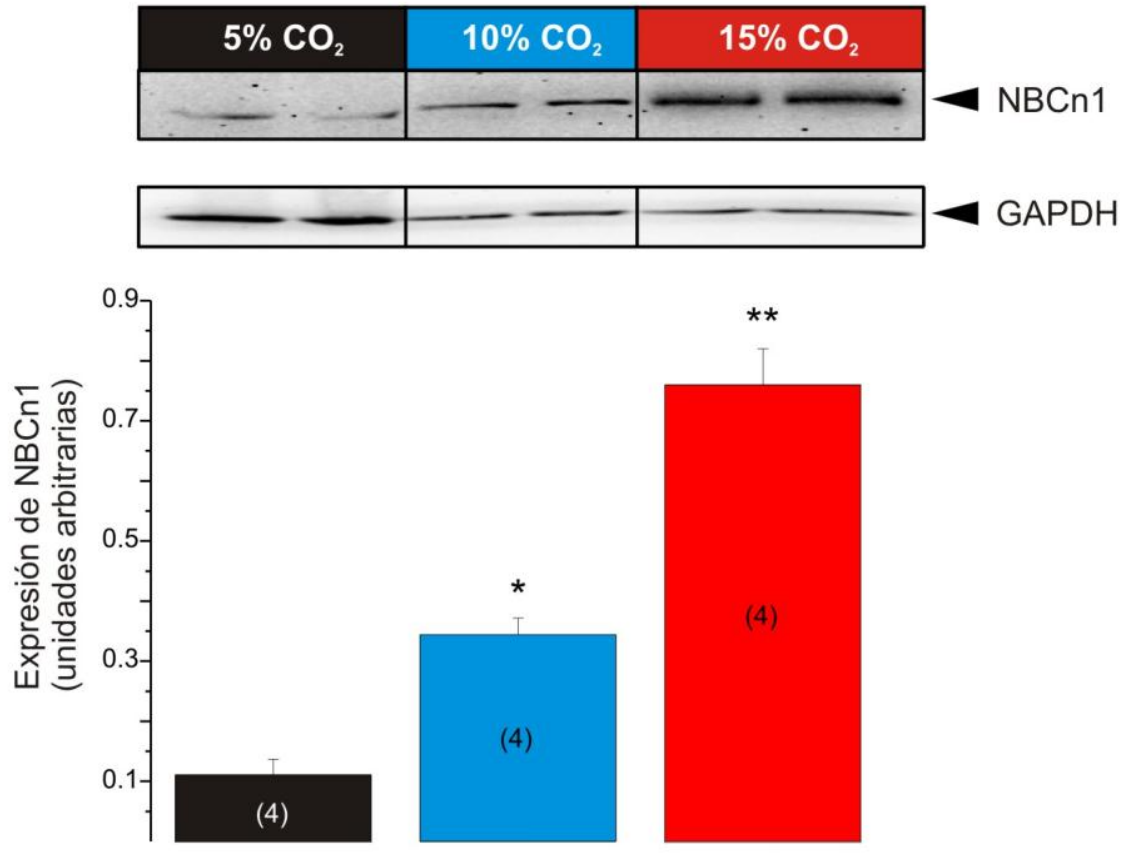

Figura IV.7: La expresión del NBCn1 se encuentra regulada positivamente por el aumento de la presión de $\mathrm{CO}_{2}$. A. Inmunoblots representativos de la expresión de NBCn1 de lisados de HEK293 luego de ser incubadas 24 horas en presencia de $5 \%, 10 \%$ y $15 \%$ de $\mathrm{CO}_{2}$. Las barras corresponden a los datos promedios de la densitometría de las bandas correspondientes a NBCn1 expresadas en unidades arbitrarias. ( $5 \%$ vs $10 \%, * p<0.05$; $10 \%$ vs $15 \% \quad * * \quad p<0.05)$. B. Inmunoblots representativos de la expresión de NBCn1 de lisados de HEK293 biotinilizadas e incubadas con la resina streptavidina/sefarosa. Las barras corresponden al \% de expresión de NBCn1 en membrana.

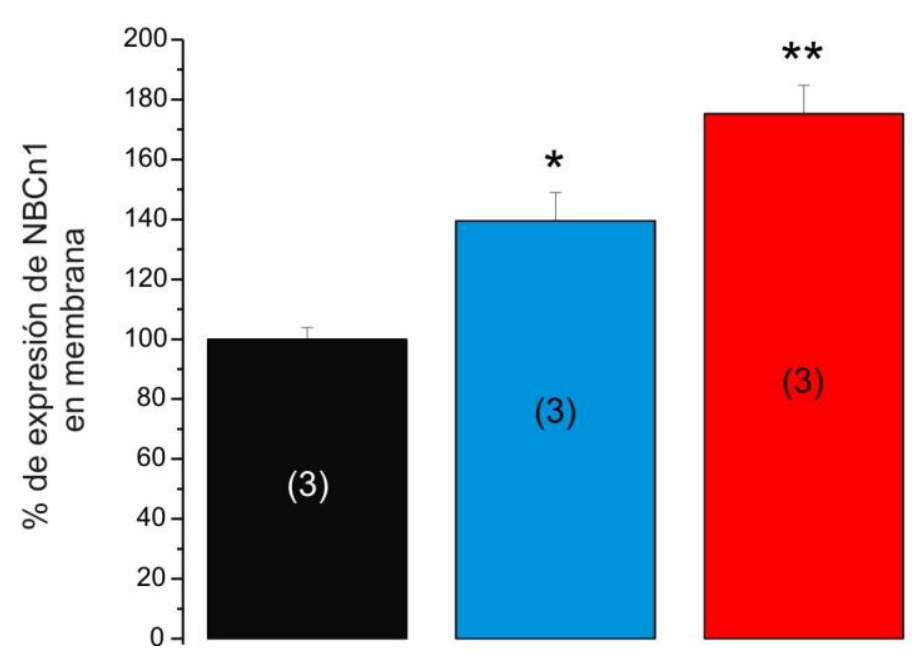

( $5 \%$ vs $10 \%,{ }^{*} p<0.05 ; 10 \%$ vs $15 \%$ ** $p<0.05)$. Entre paréntesis se detallan el número de experimentos realizados. 
Estos resultados indican que la expresión del NBCn1 se encuentra regulada positivamente por el incremento de la presión de $\mathrm{CO}_{2}$. Para detallar las implicancias fisiológicas se intentó correlacionar el aumento de la expresión del NBCn1 con la función del cotransportador.

\section{IV.5 Análisis funcional del NBCn1 en células HEK293 expuestas a altos niveles de $\mathrm{CO}_{2}$}

Se estudió la recuperación del $\mathrm{pH}_{\mathrm{i}}$ mediado por NBCn1 luego de 24 horas de incubación con diferentes presiones de $\mathrm{CO}_{2}$. Luego de las 24 horas las células fueron cargadas con el indicador fluorescente sensible a $\mathrm{pH}_{\mathrm{i}}(\mathrm{BCECF})$. Se registró la recuperación del $\mathrm{pH}_{\mathrm{i}}$ luego de un pulso de $\mathrm{NH}_{4}{ }^{+}$siempre en presencia de EIPA [30 $\left.\mu \mathrm{M}\right]$ (Figura IV.8). La velocidad de recuperación inicial en aquellas células expuestas a $10 \% \mathrm{CO}_{2}$ fue mayor con respecto al control y este aumento se incrementó aún más en aquellas expuestas a $15 \% \mathrm{CO}_{2}$.

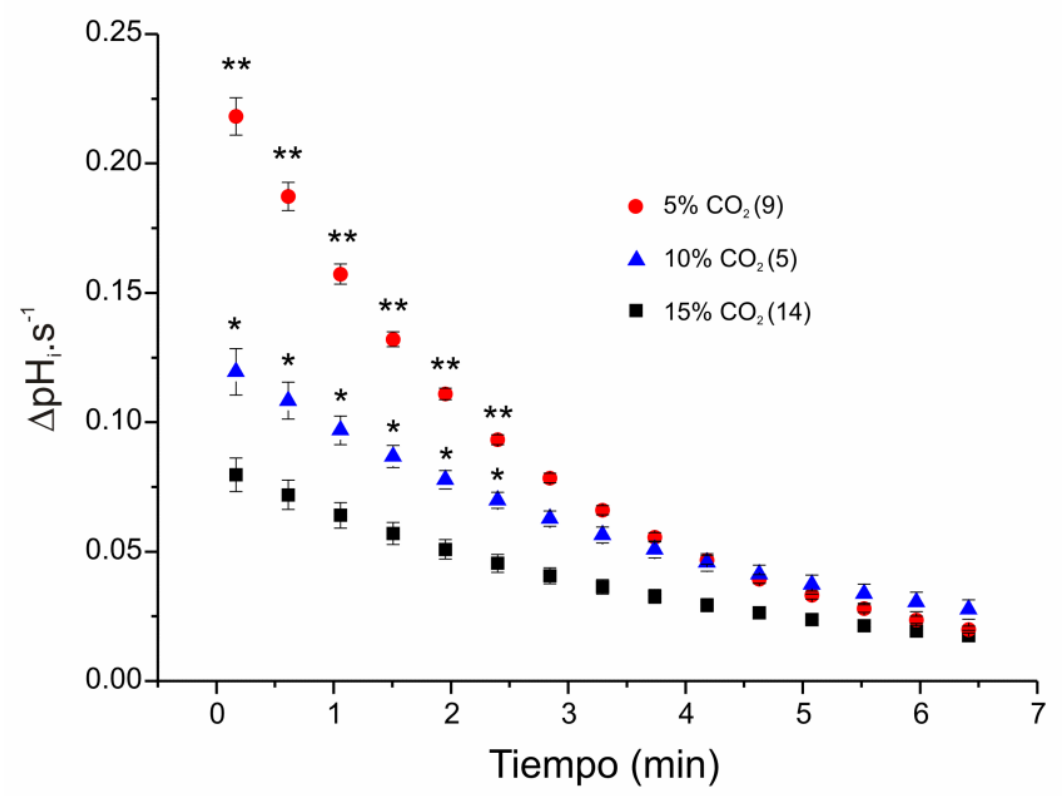

Figura IV.8: Aumento del transporte mediado por NBC por el incremento de la presión de $\mathrm{CO}_{2}$. Velocidades de recuperación del $\mathrm{pH}_{i}$ para cada una de las presiones de $\mathrm{CO}_{2}$. Se observa el aumento de las velocidades al incrementar el porcentaje de $\mathrm{CO}_{2}$. Estos resultados son consistentes con el aumento de la expresión de NBCn1. Entre paréntesis se detallan el número de experimentos realizados. (10\% vs $5 \% * p<0.05 ; 15 \%$ vs $10 \% * * p<0.05)$. 
Estos experimentos demuestran que la expresión y la función del NBCn1 se encuentran reguladas por la presión del $\mathrm{CO}_{2}$. 


\section{IV.6 Discusión}

Se demostró en células HEK293 que el 50\% de la recuperación del $\mathrm{pH}_{\mathrm{i}}$ luego de una acidosis corresponde al cotransporte $\mathrm{Na}^{+} / \mathrm{HCO}_{3}{ }^{-}$, siendo el $\mathrm{NBCn} 1$ el único transportador responsable del influjo de $\mathrm{HCO}_{3}{ }^{-}$al interior celular. El 50\% restante corresponde al $\mathrm{NHE}$ ya que puede ser inhibido por bloqueantes clásicos del intercambiador $\mathrm{Na}^{+} / \mathrm{H}^{+}$como el amiloride o el EIPA. Ha sido mostrado la expresión endógena del NHE1 [133, 134], NHE3 [135] y NH8 [136, 137] en células HEK293 como así también en diferentes tejidos de riñón.

En nuestros estudios se describió el transporte del NBC total sin diferenciar funcionalmente a qué isoforma corresponde. Sin embargo utilizando anticuerpos específicos para cada uno de los NBC obtuvimos únicamente señal para el NBCn1, descontando la presencia de NBCe1 y NBCe2. Además, la recuperación del $\mathrm{pH}_{\mathrm{i}}$ luego de la acidosis fue totalmente evitada utilizando el inhibidor selectivo para NBC, el S0859 [131, 132].

Las células HEK293 proporcionan un sistema de expresión heterólogo ampliamente utilizado en el estudio de transportadores de membrana. En la primer parte de este trabajo de tesis doctoral se utilizó este sistema de expresión para estudiar la interacción física y funcional del cotransportador NBCe1 con la AC IX siendo de gran utilidad dada su facilidad de transfección.

Demostramos en células HEK293 que el incremento de la presión de $\mathrm{CO}_{2}(10 \%, 15 \%)$ en cultivo de 24 horas, provoca el incremento de la expresión del NBCn1, correlacionado con un aumento en la actividad.

Se ha visto que ratones expuestos crónicamente a altos niveles de $\mathrm{CO}_{2}$ incrementan la expresión de proteínas encargadas de regular el $\mathrm{pH}_{\mathrm{i}}$ en cerebro, corazón y riñón [138]. Principalmente se conoce la alteración de la expresión del $\mathrm{AE} 3 \mathrm{Cl}^{-} / \mathrm{HCO}_{3}{ }^{-}$, el NHE1 $\mathrm{Na}^{+} / \mathrm{H}^{+}$así como también del NBCe1 y del NBCn1. En condiciones de hipercapnia existe una respuesta 
diferencial en cada tejido. El cerebro altera los niveles de expresión del AE3, mientras que en riñón y corazón los mayores cambios se producen con el NHE1, NBCn1 y NBCe1 [130]. Este cambio del patrón de expresión de los transportadores de $\mathrm{HCO}_{3}{ }^{-}$sugieren una respuesta adaptativa con el objetivo de atenuar los efectos deletéreos por la acidificación intracelular inducida por hipercapnia. Sin embargo, son necesarias más evidencias experimentales para examinar el mecanismo por el cual la presión de $\mathrm{CO}_{2}$ induce un aumento en la expresión del NBCn1. 


\section{Conclusiones finales}

En el presente trabajo de tesis doctoral se estudiaron tres mecanismos totalmente diferentes de regulación del cotransportador sodio/bicarbonato.

El primer mecanismo estudiado involucra la interacción física con otra proteína, la anhidrasa carbónica IX, formando lo que se denominó un metabolón de transporte iónico. Se demostró que dicha interacción es fundamental para un eficiente transporte de $\mathrm{HCO}_{3}{ }^{-}$mediado por NBCe1. Además, se sugirió una importancia fisiológica de dicho metabolón en el acoplamiento excito-contráctil del miocito cardíaco.

El segundo mecanismo estudiado corresponde a la regulación por la hormona esteroidea, aldosterona. Demostramos por primera vez la regulación postransduccional positiva del cotransportador NBC por la aldosterona y además dicha vía de activación involucra al menos dos diferentes tipos de receptores. Por un lado el clásico receptor de mineralocorticoide MR y en segundo lugar un nuevo receptor de membrana acoplado a proteína G, el GPR30. Estos hallazgos abren la puerta a futuros nuevos experimentos con el fin de dilucidar el papel fisiopatológico que ejerce la aldosterona sobre el NBC en el miocardio. 
Por último, se postuló al NBCn1 como el único mecanismo alcalinizante dependiente de $\mathrm{HCO}_{3}{ }^{-}$en la línea celular embrionaria de riñón humano (HEK293). Además, se demostró un aumento significativo en la expresión de $\mathrm{NBCn} 1$ debido al incremento de la presión de $\mathrm{CO}_{2}$ en el cultivo por 24 horas. En ensayos funcionales se halló un mayor transporte catalizado por NBCn1 debido al incremento del número de transportadores en la membrana celular. 


\section{VI}

\section{Materiales y Métodos}

\section{Vl.1 Aislamiento de miocitos cardíacos de rata}

Se utilizaron ratas Wistar machos de 4 meses de edad, a las cuales se las anestesió con una inyección intraperitoneal de pentobarbital sódico ( $35 \mathrm{mg} / \mathrm{Kg}$ de animal).

El corazón se hepariniza $(200 \mathrm{U} / \mathrm{ml})$ para evitar coágulos y se extrae rápidamente para luego ser sostenido en un sistema Langendorff (figura VI.1) y perfundido retrógradamente a través de la aorta durante 5 min con una solución HBS $(\mathrm{mM}): 146.2 \mathrm{NaCl}, 4.69 \mathrm{KCl}, 11$ glucosa, 10 HEPES, $0.35 \mathrm{NaH}_{2} \mathrm{PO}_{4} . \mathrm{H} 2 \mathrm{O}, 1.05 \mathrm{SO}_{4} \mathrm{Mg} .7 \mathrm{H}_{2} \mathrm{O}, 1 \mathrm{Cl}_{2} \mathrm{Ca}, 100 \% \mathrm{O}_{2}, \mathrm{pH} 7,4$. Una vez limpio, sin evidencia de resto de sangre, se prosigue con otra solución la cual posee el quelante de $\mathrm{Ca}^{2+}$ EGTA (0.1 mM) y en ausencia de $\mathrm{Cl}_{2} \mathrm{Ca}$. Transcurridos $5 \mathrm{~min}$, se inicia la perfusión con la solución enzimática, HEPES con $0.5 \mathrm{mM} \mathrm{Cl}{ }_{2} \mathrm{Ca}, 0,2 \mathrm{mg} / \mathrm{ml}$ de colagenasa tipo II 300U/ml (Worthington Biochemical), $0.02 \mathrm{mg} / \mathrm{ml}$ proteasa y $1 \mathrm{mg} / \mathrm{ml}$ de albúmina bovina.

Una vez finalizada la digestión, el corazón es desmontado del Langendorff, y disgregado el tejido al ser afectado mecánicamente con pinzas. 
Finalmente, se restituye progresivamente el $\mathrm{Ca}^{2+}$ de la solución con el agregado de $\mathrm{Cl}_{2} \mathrm{Ca}$ hasta lograr una concentración final de $1 \mathrm{mM}$ y de esta forma evitar la muerte celular por recalcificación rápida.
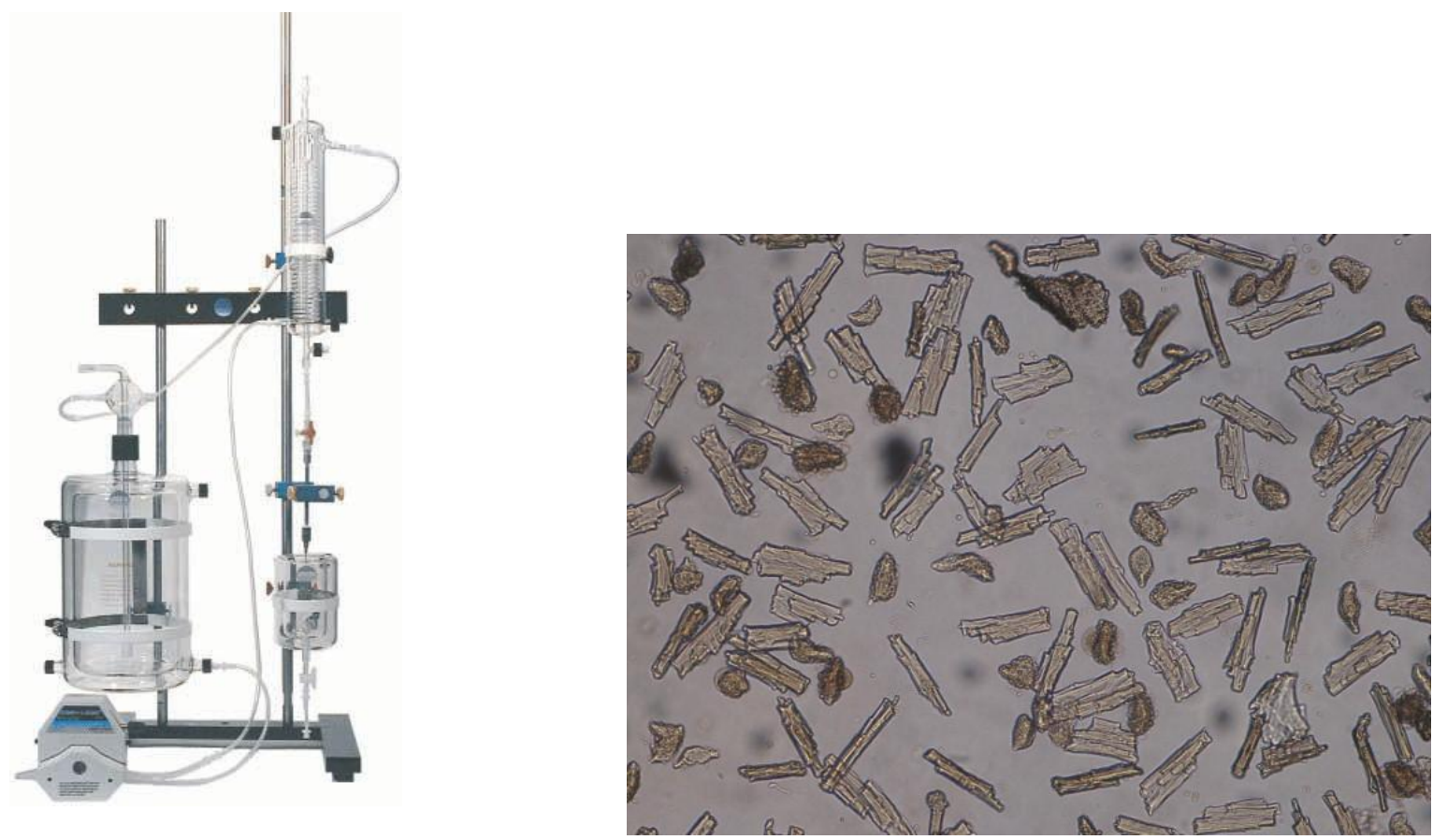

Figura VI.1: Aislamiento de miocitos cardíacos de rata. A. Sistema Langendorff de retroperfusión aórtica utilizado para el aislamiento de miocitos ventriculares de rata. B. Miocitos aislados de ventrículo de rata Wistar macho de 4 meses de edad. Fueron observados con un microscopio invertido Nikon y un objetivo de 20X acoplado a un sistema de adquisición de imágenes Nikon Digital Sight.

\section{VI.2 Cultivo de células embrionarias de riñón humano (HEK293)}

Las células HEK293 se cultivaron en recipientes T-75 (Falcón), en un medio de cultivo específico (Dulbecco's Modified Eagles Medium, DMEM, Invitrogen) suplementado con 10\% de suero fetal bovino (SFB) y en presencia de antibióticos (penicilina, estreptomicina, y gentamicina; PSG). Las células fueron mantenidas en un incubador a $37^{\circ} \mathrm{C}$, en una atmósfera 
conteniendo $5 \% \mathrm{CO}_{2}$ en aire balanceado (19:1), y se mantuvieron en cultivo hasta cumplir 25-30 pasajes.

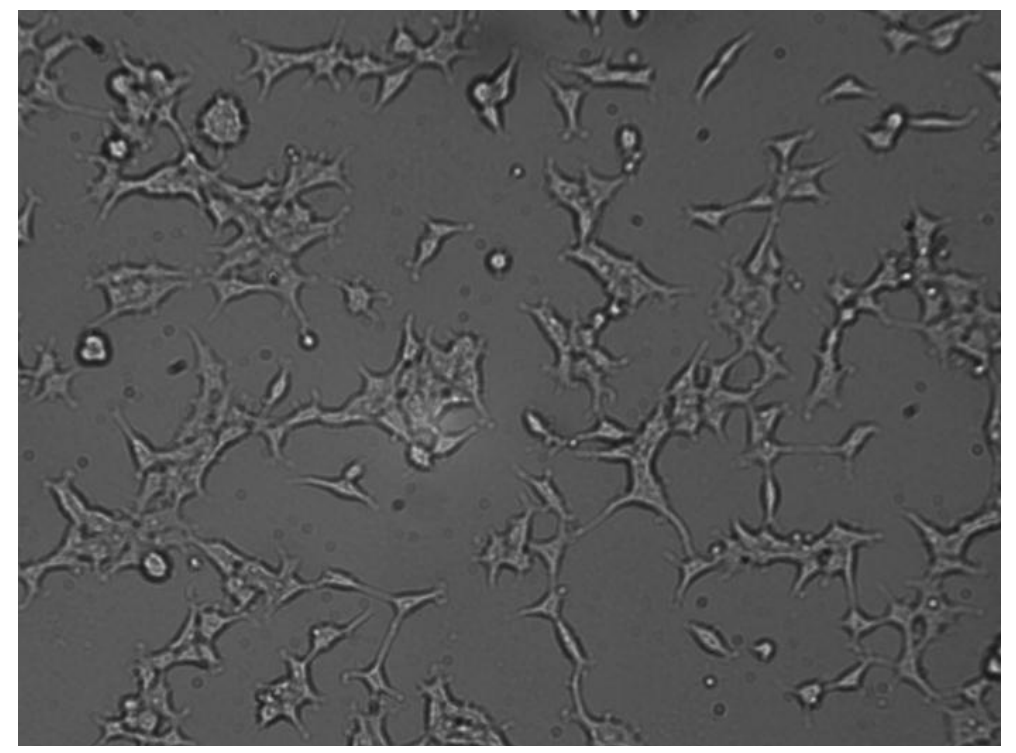

Figura VI.2: Cultivo de células HEK293. En la figura se observa un cultivo de células embrionarias de riñón humano (HEK293) crecidas en monocapa.

\section{VI.3 Determinación de $\mathrm{pH}_{\mathrm{i}}$ por epifluorescencia}

El pH intracelular $\left(\mathrm{pH}_{\mathrm{i}}\right)$ de los miocitos se midió por un sistema de epifluorescencia (Ion Optix, Milton, MA). Se utilizaron los miocitos cardíacos obtenidos en el mismo día mediante la técnica previamente descripta y mantenidos en un medio con $\mathrm{HCO}_{3}{ }^{-}$burbujeado con $\mathrm{CO}_{2} 5 \% / \mathrm{O}_{2}$

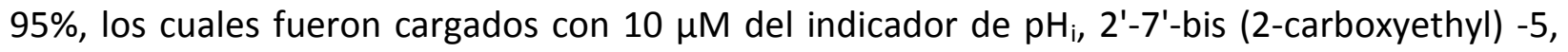
6-carboxyfluorescein (BCECF)-AM a temperatura ambiente durante 10 minutos, al cabo de los cuales se lavó el medio extracelular con solución libre de indicador.

El modo de carga del indicador se basa en que las formas "AM" o "acetoxy-metil-ester" de los indicadores fluorescentes atraviesan fácilmente la membrana, y así una vez en el citosol las esterasas intracelulares cortan la porción AM para liberar la forma ácida del indicador, que es la que posee la propiedad fluorescente cuando se combina con el ión correspondiente $\left(\mathrm{H}^{+}\right)$. 
Transcurridos 30 minutos de lavado, los miocitos fueron colocados sobre la platina de un microscopio invertido (Nikon TE 2000-U), a flujo continuo $(2 \mathrm{ml} / \mathrm{min}$ ) y estimulados a través de dos electrodos de platino a una frecuencia de $0.5 \mathrm{~Hz}$. La luz de excitación, provista por una cámara de Xenón de 75 watt, fue centrada a 440 y 490 nm y transmitida a los miocitos. La fluorescencia emitida fue colectada por un fotomultiplicador provisto de un filtro de $535 \mathrm{~nm}$. El cociente (490/440) fue digitalizado a $10 \mathrm{kHz}$ (ION WIZARD software) para análisis de fluorescencia.

Al término de cada experimento, se realizó una calibración con Nigericina y alto $\mathrm{K}^{+}$[139]. Esto permitió transformar las unidades arbitrarias de fluorescencia del cociente 490/440 en unidades de $\mathrm{pH}_{\mathrm{i}}$. Se realizó un gráfico del $\mathrm{pH}_{\mathrm{i}}$ vs el cociente 490/440, se hizo un ajuste lineal de los datos, y el valor de la ordenada al origen y la pendiente de la ecuación general de la recta fueron utilizados para reemplazar los datos de fluorescencia.

\section{VI.4 Pulso de $\mathrm{NH}_{4}{ }^{+}$en miocitos ventriculares de rata}

Se utilizó la técnica denominada Pulso de $\mathrm{NH}_{4}{ }^{+}$para determinar la actividad total del transporte mediado por NBC (NBCe1+NBCn1).

El fundamento de la técnica se resume en la figura VI.3. Inicialmente los miocitos fueron expuestos a una solución extracelular de $\mathrm{HCO}_{3}{ }^{-}$burbujeado con $\mathrm{CO}_{2} 5 \% / \mathrm{O}_{2} 95 \%$, registrándose el $\mathrm{pH}_{\mathrm{i}}$ hasta su estabilización. Al exponer los miocitos a $\mathrm{NH}_{4} \mathrm{Cl} 20 \mathrm{mM}$ durante 3 minutos se genera una alcalosis intracelular debido a la difusión rápida, a través de la membrana, del amoníaco $\left(\mathrm{NH}_{3}\right)$ y la siguiente asociación de esta molécula con los $\mathrm{H}^{+}$intracelulares.

Más lentamente a la vez difunde el $\mathrm{NH}_{4}{ }^{+}$, el cual se disocia y aporta una cantidad extra de $\mathrm{H}^{+}$al medio intracelular, produciendo una leve caída del $\mathrm{pH}_{\mathrm{i}}$. Cuando el $\mathrm{NH}_{4} \mathrm{Cl}$ es removido y los miocitos vuelven a exponerse a la solución de $\mathrm{HCO}_{3}^{-}$inicial, se evidencia una rápida 
acidificación celular debida a la generación intracelular de $\mathrm{H}^{+}$, secundaria a la disociación del $\mathrm{NH}_{4}^{+}$en $\mathrm{H}^{+}$y $\mathrm{NH}_{3}$ y al aporte de $\mathrm{H}^{+}$provenientes de la difusión lenta del $\mathrm{NH}_{4}^{+}$.

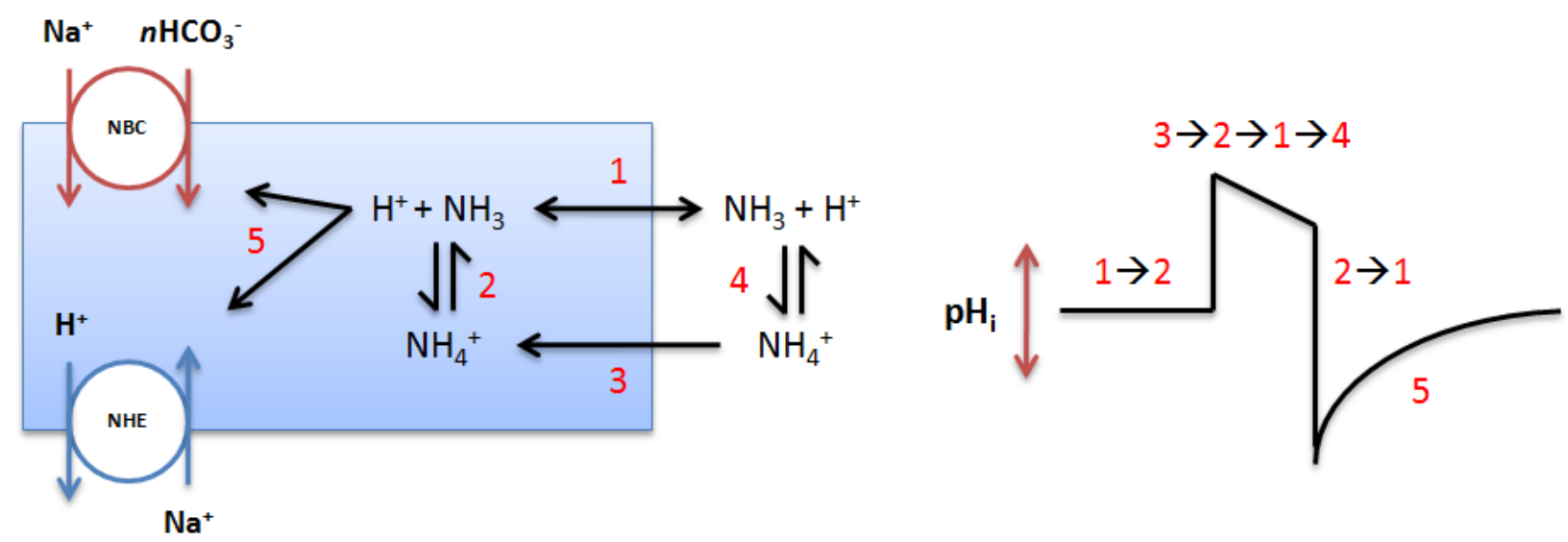

Figura VI.3: Esquema del fundamento del Pulso de Amonio. El $\mathrm{NH}_{3}$ ingresa a la célula produciendo la alcalinización. Una vez que se quita el $\mathrm{NH}_{4}{ }^{+}$del medio extracelular se genera una rápida acidificación producto de la disociación del $\mathrm{NH}_{4}{ }^{+}$. La activación de los mecanismos alcalinizantes: NBC y NHE provocan la recuperación del $\mathrm{pH}_{\mathrm{i}}$.

Dado que el $\mathrm{NH}_{3}$ es permeable, sale de la célula, y los $\mathrm{H}^{+}$que permanecen en el interior son los responsables de la disminución del $\mathrm{pH}_{\mathrm{i}}$.

Esta acidosis intracelular activa a los mecanismos celulares alcalinizantes (NHE y NBC), encargados de llevar el $\mathrm{pH}_{\mathrm{i}}$ a sus valores basales.

El análisis de los datos se realizó en el programa de computación Origin 7.0, ajustando la curva de recuperación con una función exponencial de primer orden. De este ajuste se obtuvo la velocidad $\left(\mathrm{dpH}_{\mathrm{i}} / \mathrm{dt}\right)$ de recuperación a cada $\mathrm{pH}_{\mathrm{i}}$ y luego, con este dato y conociendo la capacidad amortiguadora total ( $\beta$ tot), se calculó el flujo de protones $(\mathrm{JH})$ en $\mathrm{mM} / \mathrm{min}$ (JH= $\beta$ tot $\mathrm{dpH} / \mathrm{dt}$ ). La $\beta$ tot fue calculada a partir de la suma entre la capacidad amortiguadora del $\mathrm{CO}_{2}$ intracelular $\left(\beta \mathrm{CO}_{2}\right)$ y la capacidad amortiguadora intrínseca $\left(\beta_{\mathrm{i}}\right)$.

La $\beta \mathrm{CO}_{2}$ fue calculada como, $\beta \mathrm{CO}_{2}=2.3\left[\mathrm{HCO}_{3}^{-}\right]_{\text {i }}$, donde $\left[\mathrm{HCO}_{3}\right]_{\mathrm{i}}=\left[\mathrm{HCO}_{3}^{-}\right]_{\mathrm{o}} 10 \mathrm{pH}_{\mathrm{i}}-\mathrm{pH}_{\mathrm{o}}$ [129]. La $\beta_{\mathrm{i}}$ de los miocitos fue calculada exponiendo las células a diferentes concentraciones de $\mathrm{NH}_{4} \mathrm{Cl}(20,15,12,9,5$ y $3 \mathrm{mmol} / \mathrm{L})$ en buffer HEPES $\sin \mathrm{Na}^{+}$y registrando el $\mathrm{pH}_{\mathrm{i}}$ obtenido para 
cada concentración de $\mathrm{NH}_{4} \mathrm{Cl}$ durante 3 minutos, utilizando luego el promedio de los valores del último minuto en cada situación. Sabiendo que: $\mathrm{NH}_{4}{ }^{+}{ }_{\mathrm{i}}=\mathrm{NH}_{4}{ }^{+} \times 10\left(\mathrm{pH}_{0}-\mathrm{pH}_{\mathrm{i}}\right) / 1+10\left(\mathrm{pH}_{\mathrm{o}}-\mathrm{pK}\right)$, la $\beta_{\mathrm{i}}$ se calculó como $\beta_{\mathrm{i}}=\Delta\left[\mathrm{NH}_{4}^{+}\right]_{\mathrm{i}} / \Delta \mathrm{pH}_{\mathrm{i}}$, y referida al punto medio de las medidas de $\mathrm{pH}_{\mathrm{i}}$. $\mathrm{pK}$ del $\mathrm{NH}_{4}{ }^{+}=9.21 \mathrm{y}$ el $\mathrm{pH}_{\mathrm{o}}=7.4$ [140]. La $\beta_{\mathrm{i}}$ a diferentes valores de $\mathrm{pH}_{\mathrm{i}}$ fue estimada sobre un ajuste lineal obtenido de la gráfica entre la $\beta_{\mathrm{i}}$ en función del $\mathrm{pH}_{\mathrm{i}}$.

\section{VI.5 Pulsos de $\mathrm{NH}_{4}{ }^{+}$en células HEK293}

Células HEK293 fueron crecidas en cultivo hasta un 80\% de confluencia en un flask T75. Se les remueve el medio de cultivo y luego de ser lavadas con un buffer fosfato salino (PBS) son resuspendidas utilizando una solución $0.25 \%$ de tripsina y $1 \mathrm{mM}$ de EDTA.

La suspensión de células es cargada con $10 \mathrm{mg} / \mathrm{ml}$ de BCECF-AM, el indicador fluorescente sensible a $\mathrm{pH}_{\mathrm{i}}$, por $20 \mathrm{~min}$ a $37^{\circ} \mathrm{C}$ en un $1 \mathrm{ml}$ de buffer HBS. Luego de un lavado, se mantienen por $10 \mathrm{~min}$ a $37{ }^{\circ} \mathrm{C}$ para completar la hidrólisis del indicador. Se procede a realizar el pulso de $\mathrm{NH}_{4}{ }^{+}$para generar la acidosis intracelular (ver pulso de $\mathrm{NH}_{4}{ }^{+}$en miocitos ventriculares de rata). Las células son incubadas con $10 \mathrm{mM}$ de $\mathrm{NH}_{4}{ }^{+}$por $4 \mathrm{~min}$, luego centrifugadas $\mathrm{y}$ resuspendidas en una solución HBS cero sodio para mantener las células acidificadas. Se toman $100 \mu \mathrm{l}$ de las células acidificadas y se resuspenden en $2 \mathrm{ml}$ de un buffer $\mathrm{HCO}_{3}{ }^{-}$. Las células cargadas y acidificadas cuando se encuentran con buffer en presencia de $\mathrm{Na}^{+}$inician la recuperación del $\mathrm{pH}_{\mathrm{i}}$, registrándose mediante la excitación alternativamente con haces luminosos de 503 y $440 \mathrm{~nm}$, y la luz emitida se mide a $535 \mathrm{~nm}$. El pH $\mathrm{pH}_{\mathrm{i}}$ se calcula a partir de una curva de calibración en $\mathrm{HBS} / \mathrm{K} /$ nigericina. La nigericina permite el intercambio iónico libre a través de la membrana celular igualando el $\mathrm{pH}_{\mathrm{i}}$ con el $\mathrm{pH}_{\mathrm{e}}$, al modificar este último por agregados de $\mathrm{KOH} 2 \mathrm{M}$ o $\mathrm{HCl} 0.1 \mathrm{M}$ y registrando la fluorescencia del indicador en cada punto obtendremos una relación lineal entre la fluorescencia 503/440 y el pH intracelular. 

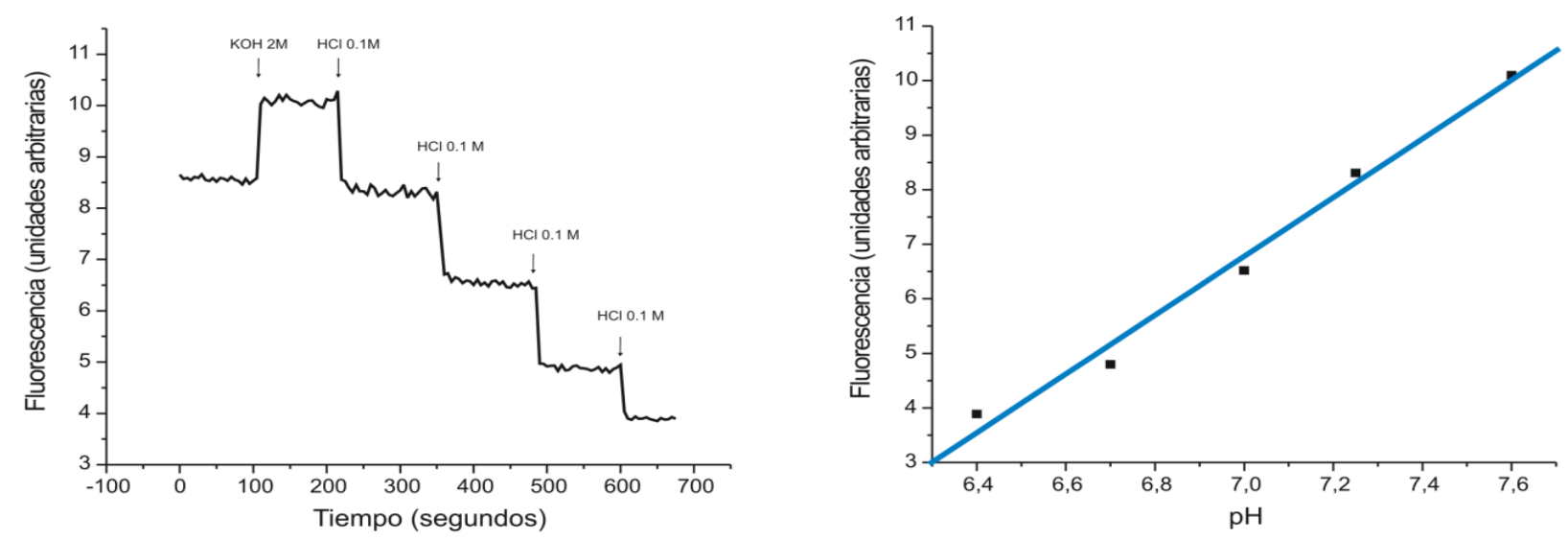

Figura VI.4: Construcción de la curva de calibración de pH en función de la fluorescencia emitida para un experimento típico.

\section{VI.6 Despolarización por alto $\mathrm{K}^{+}$}

Se estudió la actividad del NBC electrogénico (NBCe1) con un protocolo experimental denominado "Despolarización por alto $\mathrm{K}^{+}$", donde los miocitos aislados son expuestos a una solución que contiene: (mM) $118 \mathrm{NaCl}, 5 \mathrm{KCl}, 1 \mathrm{MgSO}_{4}, 0.35 \mathrm{NaH}_{2} \mathrm{PO}_{4}, 10$ glucosa, 40 cloruro de colina, $20 \mathrm{NaHCO}_{3}, \mathrm{pH} 7.45 \mathrm{mM}$, y una vez estabilizado el registro de $\mathrm{pH}_{\mathrm{i}}$, se modifica a una solución isosmótica pero con $45 \mathrm{mM}$ de $\mathrm{K}^{+}$manteniéndose por 14 minutos.

La mayor concentración de $\mathrm{K}^{+}$de la solución produce una despolarización de la célula de aproximadamente $60 \mathrm{mV}$, activando todos los mecanismos electrogénicos, entre ellos el NBCe1. La activación del NBCe1 se traducirá como un incremento del $\mathrm{pH}_{\mathrm{i}}$. Al volver a la solución inicial, el $\mathrm{pH}_{\mathrm{i}}$ disminuye a los valores basales. 

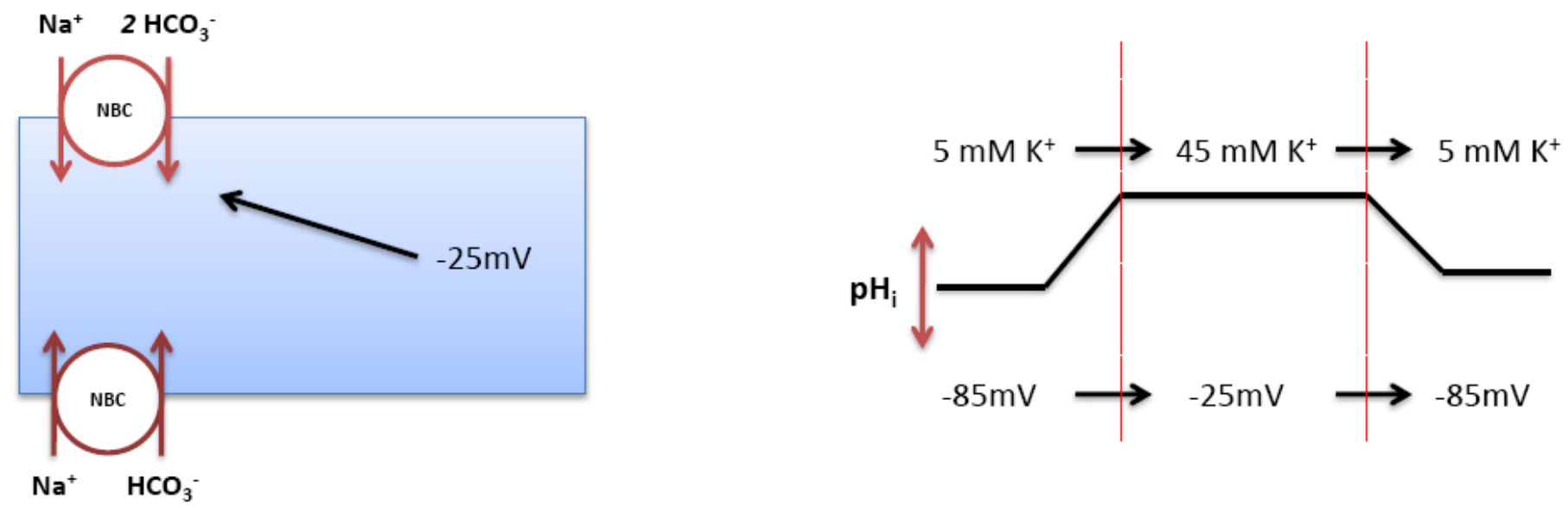

Figura VI.5: Esquema de la despolarización con alto $\mathrm{K}^{+}$. El aumento de $\mathrm{K}^{+}$extracelular produce una despolarización de aproximadamente $60 \mathrm{mV}$ activando únicamente los mecanismos electrogénicos, entre ellos el NBCe1. La activación provoca que el $\mathrm{pH}_{\mathrm{i}}$ aumente.

\section{VI.7 Expresión transitoria de ADNc en sistemas heterólogos}

Los clones de cADN de interés utilizados en esta tesis han sido insertados en vectores de expresión de células de mamífero (pCDNA3 o similares), los cuales tienen la particularidad de tener un gen promotor del citomegalovirus humano, con alta expresión en células de mamíferos. Células HEK293 cultivadas al $20 \%$ de confluencia en cajas de petri de $10 \mathrm{~cm}$ fueron transfectadas mediante el método del fosfato de calcio descripto por Ruetz el al. [141]. Se utiliza una solución taponada con HEPES e iones fosfato la cual al combinarse con otra solución que tiene $\mathrm{Cl}_{2} \mathrm{Ca}$ y el plásmido con el cADN de interés se forma un precipitado dado por el $\mathrm{Ca}_{3}\left(\mathrm{PO}_{4}\right)_{2}$. Esta suspensión es agregada a las células en cultivo y por un mecanismo aun no del todo comprendido las células incorporan el precipitado conjuntamente con el ADN [141]. 


\section{VI.8 Análisis de proteínas por Western-blots}

Células HEK transfectadas con los CADN codificantes de las proteínas de interés (NBCs, AC) se mantuvieron en cultivo por 36-48 horas post-transfección. Luego de este período, tanto las células, como homogenatos preparados de corazón entero, o bien de ventrículos aislados de corazones de rata (previa disrupción del tejido con un Polytron o equivalente), fueron lavados con PBS (mM) $\left.140 \mathrm{CINa}, 3 \mathrm{ClK}, 6.5 \mathrm{HPO}_{4} \mathrm{Na}_{2}, 1.5 \mathrm{H}_{2} \mathrm{PO}_{4} \mathrm{~K}, \mathrm{pH} 7.4\right)$ y los lisados de células o tejidos, preparados por adición de buffer de carga SDS/PAGE ((10\% (v/v) de glicerol, 1-3\% (v/v) 2-mercaptoetanol, 2\% (p/v) SDS, 0.5\% (p/v) de azul de bromofenol, $75 \mathrm{mM}$ Tris, pH 6.8)) conteniendo inhibidores de proteasas (MiniComplete Tablets, Roche).

Las muestras fueron resueltas en geles de $7.5-12 \%$ de poliacrilamida, dependiendo del peso molecular de la proteína en estudio, luego se transfirieron a membranas de PVDF por electroforesis (SDS-PAGE). Las membranas son bloqueadas con una solución que contiene leche al $10 \%$ para luego ser incubadas toda la noche con los anticuerpos específicos para cada una de las proteínas de interés. Al día siguiente se incuba por 1 hora con los anticuerpos secundarios los cuales están conjugados con una peroxidasa de rabanito. La detección de las proteínas inmunoreactivas se hizo por quimioluminiscencia (Amersham) y las señales se cuantificaron mediante análisis densitométrico. Los blots serán visualizados por quimioluminiscencia con $E C L^{\circledR}$ y cuantificados en una Estación de Imagen de Bio-Rad.

\section{VI.9 Coinmunoprecipitaciones}

Corazones de rata o células HEK293 transfectadas con NBCs y/o ACs fueron lisados en un buffer IP: 10mM Tris-HCl, pH 7.5 1\% NP40, 5 mM EDTA, 0.15 M NaCl, 0.5\% Deoxicolato, inhibidores de proteasas (Roche), e inmunoprecipitados con anticuerpos específicos contra AC II, AC IV, AC IX o con suero no-inmune (suero no relevante). El lisado se incuba en agitación con 
proteína-A-sefarosa y el anticuerpo especifico de la proteína a precipitar, luego, la muestra se centrifuga a 9000 rpm para bajar la sefarosa y se descarta el sobrenadante, el cual es lavado consecutivamente con 3 soluciones (Sol1: 10 mM Tris- $\mathrm{HCl}, \mathrm{pH}$ 7.5, 0.1\% NP40, 1mM EDTA, 0.15 M CINa. Sol2: 10mM Tris- $\mathrm{HCl}, \mathrm{pH}$ 7.5, 2 mM EDTA, 0.05\% SDS. Sol3: 10mM Tris- $\mathrm{HCl}, \mathrm{pH} 7.5,2$ mM EDTA), para luego ser resuspendido en el buffer de carga. Las muestras preparadas serán sometidas a electroforesis en geles de 7-8\% de acrilamida (SDS-PAGE), transferidas a membranas de PVDF, y analizadas con anticuerpos específicos contra NBC.

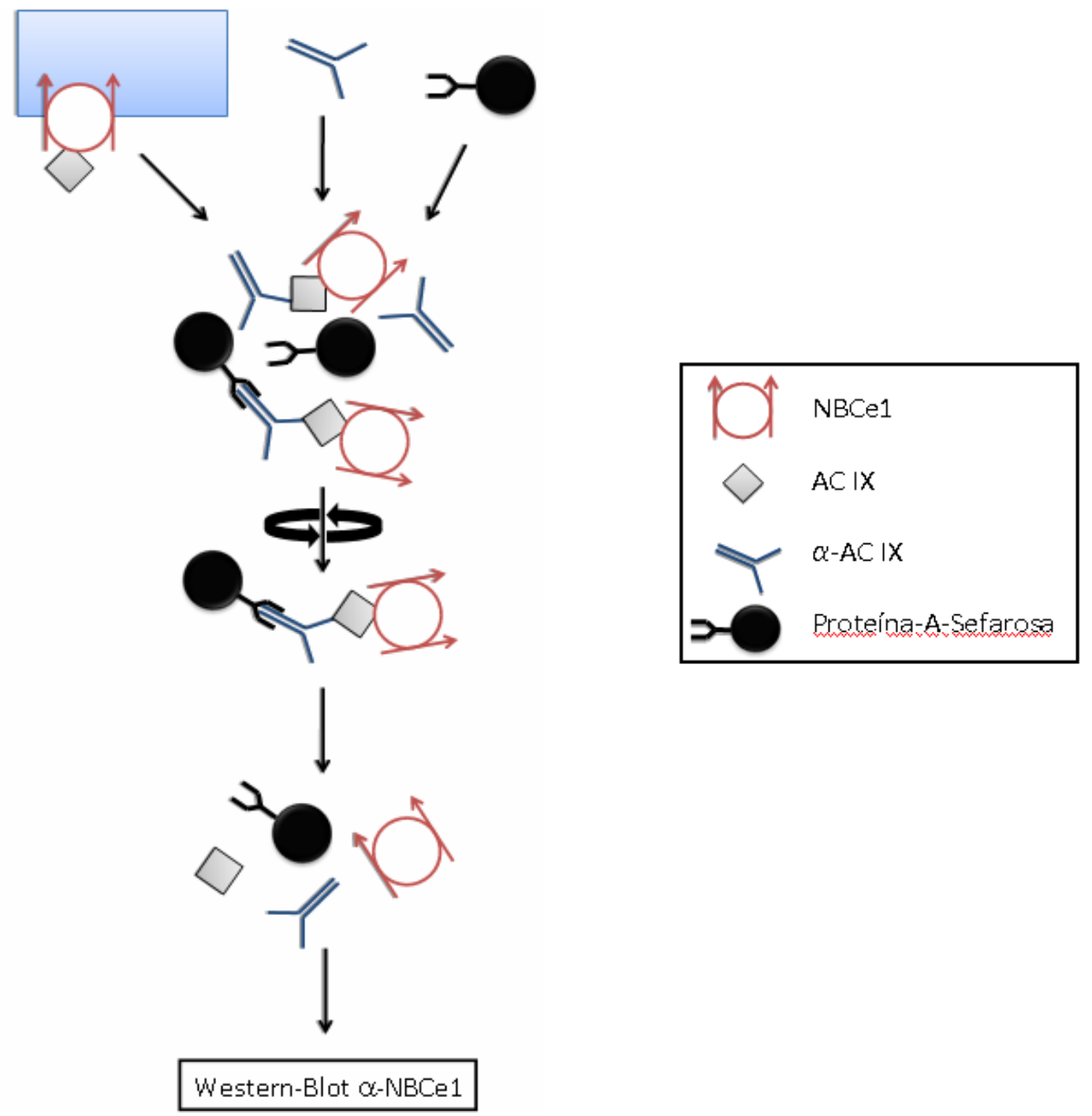

Figura VI.6: Ensayo de coinmunoprecipitación. En la figura se esquematiza el procedimiento realizado en donde se utiliza un anticuerpo unido a proteína-A-sefarosa para precipitar de un lisado de corazón o HEK una AC, luego se detecta la presencia en el precipitado de NBC mediante la técnica de Western-blot y utilizando un anticuerpo especifico contra NBC. 


\section{VI.10 Ensayo de GST Pull down}

Se transformaron E. Coli (BL21 (DE3) codón plus) con los plásmidos para la producción de las siguientes proteínas de fusión: GST-AE1EC4, GST-NBC1EC3, GST-NBC1EC4. Estas proteínas corresponden a los bucles extracelulares del NBCe1 (EC3 y EC4) y del AE1 (EC4). Para su purificación, $2 \mathrm{nM}$ de cada una de las proteínas recombinantes fue incubada con $100 \mu \mathrm{L}$ de glutatión Sefarosa 4B (Amershan Biosciences)

Una vez obtenidas las proteínas purificadas se las incubó toda la noche con un lisado de células HEK293 transfectadas con AC IX, para luego ser lavadas con PBS y eluídas con buffer SDS-PAGE a $65 \mathrm{C}$ por $5 \mathrm{~min}$.

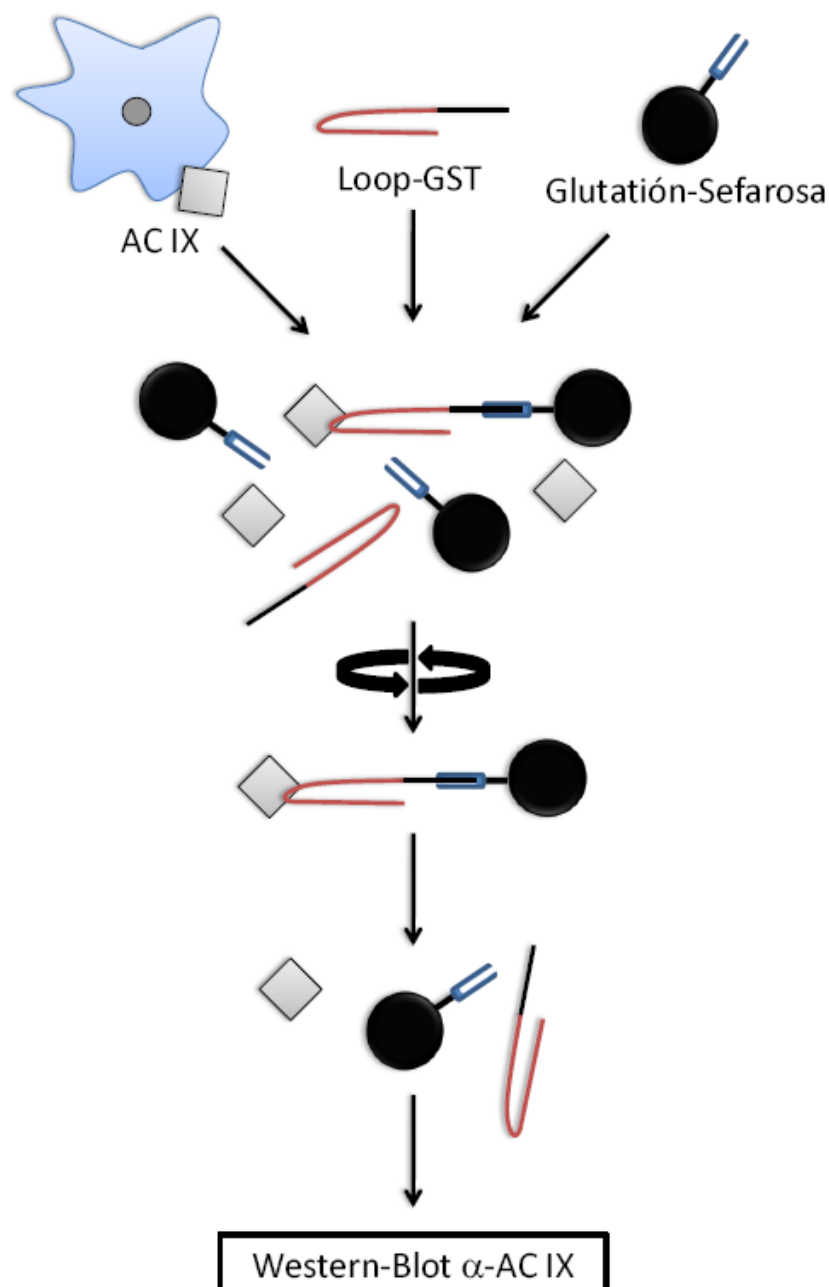

Figura VI.7: Ensayo de GST Pull down. Se esquematiza el procedimiento en el cual un pequeño péptido fusionado a GST es utilizado para precipitar aquellas proteínas que interaccionan con éste, debido a la capacidad de GST a unirse a Glutatión.

Western-Blot $\alpha$-AC IX 


\section{VI.11 Análisis de expresión de proteínas de membrana.}

Se utilizaron células HEK293 crecidas en cultivo a $37{ }^{\circ} \mathrm{C}$ bajo condiciones normales (5\%) o en altas presiones de $\mathrm{CO}_{2}$ (10\%-15\%). Las células fueron incubadas con Sulpho-NHS-SS-biotina (Thermo Scientific) y posteriomente lisadas en buffer RIPA el cual contiene inhibidores de proteasas (MiniComplet Tablet, Roche). Luego de una centrifugación a $14.000 \mathrm{~g}$ por $15 \mathrm{~min}$ y descartado el precipitado se cuantificó la cantidad de proteína total obtenida. $1000 \mu \mathrm{g}$ de proteína fue incubada con $100 \mu$ de la resina sefarosa asociada con estreptavidina (Thermo Scientific) y se incubó toda la noche a $4{ }^{\circ} \mathrm{C}$ con agitación para favorecer la unión entre la biotina y la estreptavidina. La resina es lavada repetidas veces con el buffer RIPA con el fin de eliminar aquellas proteínas unidas inespecíficamente. Las proteínas se eluyeron por la adición del buffer de muestra. La expresión de NBCn1 en membrana se determinó por Western-blot utilizando anticuerpos específicos. Se cuantificó la expresión de proteínas mediante densitometría usando la estación de imágenes BioRad.

\section{VI.12 Determinación de la expresión de transcriptos por RT-PCR}

Se aisló el ARN total de un cultivo de células HEK293 utilizando el kit commercial RNeasy Min Kits (Qiagen, USA). Se obtuvo el ADNc a través de la reacción catalizada por la transcriptasa reversa $(2 \mathrm{U} / \mu \mathrm{l})$ Superscript /I Reverse Transcriptase (Invitrogen). Para la reacción de PCR (HotStar Taq Master Mix, Qiagen) se utilizó 10\% del cDNA y 1 pmol de cada uno de los primers (tabla VI.1). El protocolo del termociclador consistió en un único calentamiento por 15 min a 95 ${ }^{\circ} \mathrm{C}$ seguido de 30 ciclos de $30 \mathrm{seg}$. a $60^{\circ} \mathrm{C}$ de hibridización, 1 min de elongación a $72{ }^{\circ} \mathrm{C}, 30 \mathrm{seg}$. a $95{ }^{\circ} \mathrm{C}$ de desnaturalización. Se utilizó $\beta$-actin como un control positivo del ADNc molde obtenido. Los productos de PCR fueron separados por electroforesis en un gel de agarosa al $2 \%$. Para su visualización se utilizó GelRed Nucleic Acid Satín (Invitrogen) y se fotografió bajo un transiluminador ultravioleta. 


\begin{tabular}{|c|c|c|c|}
\hline Transcripto & Dirección & Secuencia & $\begin{array}{l}\text { Tamaño del } \\
\text { producto }\end{array}$ \\
\hline NBCe1 & $\begin{array}{l}\text { Forward } \\
\text { Reverse }\end{array}$ & $\begin{array}{l}\text { GGTGTGCAGTTCATGGATCGTC } \\
\text { GTCACTGTCCAGACTTCCCTTC }\end{array}$ & $336 \mathrm{pb}$ \\
\hline NBCe2 & $\begin{array}{l}\text { Forward } \\
\text { Reverse }\end{array}$ & $\begin{array}{l}\text { ATCTTCATGGACCAGCAGATCAC } \\
\text { TGCTTGGCTGGCATCAGGAAG }\end{array}$ & $468 \mathrm{pb}$ \\
\hline $\mathrm{NBCn} 1$ & $\begin{array}{l}\text { Forward } \\
\text { Reverse }\end{array}$ & $\begin{array}{l}\text { CAGATGCAAGCAGCCTTGTGTG } \\
\text { GGTCCATGATGACCACAAGCTG }\end{array}$ & $328 \mathrm{pb}$ \\
\hline$\beta$-Actina & $\begin{array}{l}\text { Forward } \\
\text { Reverse }\end{array}$ & $\begin{array}{l}\text { AGAAGAGCTACGAGCTGCCTG } \\
\text { CTCCTGCTTGCTGATCCACATC }\end{array}$ & 373 pb \\
\hline
\end{tabular}

Tabla VI.1: Secuencia de los primers utilizados en la reacción de PCR.

\section{VI.13 Inmunofluorescencia y análisis por microscopía confocal}

Se adhirieron miocitos ventriculares de rata a cubreobjetos tratados con laminina (30ug/ml). Las células luego son fijadas con paraformaldehído al $4 \%$ y permeabilizadas con $0.1 \%$ de tritón X-100. Luego de varios lavados con PBS se bloquea con una solución 5\% de Albúmina + $2 \%$ de Suero de pollo. Se incuba por toda la noche con el anticuerpo primario (1:100). Al día siguiente, se lava repetidas veces con PBS + 0.2\% de gelatina, y se prosigue por la incubación del anticuerpo secundario, AlexaFluor 488 o AlexaFluor 594 (1:200) por 90 min. Se lavan 3 veces con PBS $+0.2 \%$ gelatina y se montan en portaobjetos para poder ser visualizados en un microscopio confocal. Las imágenes fueron obtenidas utilizando un objetivo de inmersión en aceite X60 1.4, y capturadas de manera secuencial para luego ser analizadas con el programa Image Pro Plus. 


\section{VI.14 Soluciones}

\section{Ringer}

En mmol/L: $20.2 \mathrm{NaHCO}_{3}, 128.3 \mathrm{NaCl}, 11$ glucosa, $4.5 \mathrm{KCl} ; 0.35 \mathrm{NaHPO}_{4} ; 1.05 \mathrm{MgSO}_{4} \mathrm{CaCl}_{2} 1$ equilibrado a $\mathrm{pH} 7.4$ con una mezcla gaseosa de $\mathrm{CO}_{2} 5 \%$ y $95 \%$ de $\mathrm{O}_{2}$

\section{HBS}

En mmol/L: $\mathrm{NaCl}$ 146.2; HEPES 10; glucosa 11; $\mathrm{KCl}$ 4.69; $\mathrm{NaHPO}_{4}$ 0.35; $\mathrm{MgSO}_{4} 1.05,1.35 \mathrm{CaCl}_{2}$ llevado a $\mathrm{pH} 7.4$ con $\mathrm{NaOH}$.

PBS

En mmol/L: $137 \mathrm{NaCl} ; 2.7 \mathrm{KCl} ; 10 \mathrm{NaHPO}_{4} ; 2 \mathrm{KH}_{2} \mathrm{PO}_{4}$.

\section{Lisis Buffer}

En mmol/L: 50 Tris-HCl, 5 EGTA, 2 EDTA, 100 FNa, $1 \mathrm{NaVO}_{4}, 0.05 \%$ Tritón X-100 a pH 7.5

\section{Buffer de muestra}

$20 \%$ glicerol; 4\% SDS; $10 \% \beta$-mercaptoetanol; $0.004 \%$ azul de bromofenol; $0.125 \mathrm{mM} \mathrm{Tris-Cl} \mathrm{a}$ $\mathrm{pH} 6.8$.

\section{VI.15 Análisis estadístico}

Los datos fueron expresados como la media \pm el error estándar (ES), siendo comparados con el test de Student o con ANOVA, seguido de un test de Student-Newman- Keuls. Se consideró un valor $\mathrm{p}<0.05$ estadísticamente significativo. 


\section{VII}

\section{Referencias}

1. Harrison, S.M., et al., Contraction and intracellular $\mathrm{Ca2+}+\mathrm{Na}+$, and $\mathrm{H}+$ during acidosis in rat ventricular myocytes. Am J Physiol, 1992. 262(2 Pt 1): p. C348-57.

2. Orchard, C.H. and J.C. Kentish, Effects of changes of $\mathrm{pH}$ on the contractile function of cardiac muscle. Am J Physiol, 1990. 258(6 Pt 1): p. C967-81.

3. Choi, H.S., et al., The effect of acidosis on systolic Ca2+ and sarcoplasmic reticulum calcium content in isolated rat ventricular myocytes. J Physiol, 2000. 529 Pt 3: p. 661-8.

4. Orchard, C.H. and H.E. Cingolani, Acidosis and arrhythmias in cardiac muscle. Cardiovasc Res, 1994. 28(9): p. 1312-9.

5. Vaughan-Jones, R.D., K.W. Spitzer, and P. Swietach, Intracellular pH regulation in heart. J Mol Cell Cardiol, 2009. 46(3): p. 318-31.

6. Orlowski, J. and S. Grinstein, Diversity of the mammalian sodium/proton exchanger SLC9 gene family. Pflugers Arch, 2004. 447(5): p. 549-65.

7. Sardet, C., A. Franchi, and J. Pouyssegur, Molecular cloning, primary structure, and expression of the human growth factor-activatable $\mathrm{Na}+/ \mathrm{H}+$ antiporter. Cell, 1989. 56(2): p. 271-80.

8. Romero, M.F., C.M. Fulton, and W.F. Boron, The SLC4 family of HCO 3 - transporters. Pflugers Arch, 2004. 447(5): p. 495-509.

9. Alvarez, B.V., et al., Slc26a6: a cardiac chloride-hydroxyl exchanger and predominant chloridebicarbonate exchanger of the mouse heart. J Physiol, 2004. 561(Pt 3): p. 721-34.

10. Niederer, S.A., et al., Measuring and modeling chloride-hydroxyl exchange in the Guinea-pig ventricular myocyte. Biophys J, 2008. 94(6): p. 2385-403.

11. Shcheynikov, N., et al., Coupling modes and stoichiometry of $\mathrm{Cl}-/ \mathrm{HCO}$ - exchange by s/c26a3 and slc26a6. J Gen Physiol, 2006. 127(5): p. 511-24.

12. Boron, W.F. and E.L. Boulpaep, Intracellular $p H$ regulation in the renal proximal tubule of the salamander. Basolateral HCO3- transport. J Gen Physiol, 1983. 81(1): p. 53-94.

13. Romero, M.F., et al., Expression cloning and characterization of a renal electrogenic $\mathrm{Na}+$ /HCO3- cotransporter. Nature, 1997. 387(6631): p. 409-13. 
14. Burnham, C.E., et al., Cloning and functional expression of a human kidney $\mathrm{Na+}$ :HCO3cotransporter. J Biol Chem, 1997. 272(31): p. 19111-4.

15. Romero, M.F., et al., Cloning and functional expression of $r \mathrm{NBC}$, an electrogenic $\mathrm{Na}(+)-\mathrm{HCO}-$ cotransporter from rat kidney. Am J Physiol, 1998. 274(2 Pt 2): p. F425-32.

16. Abuladze, N., et al., Molecular cloning, chromosomal localization, tissue distribution, and functional expression of the human pancreatic sodium bicarbonate cotransporter. J Biol Chem, 1998. 273(28): p. 17689-95.

17. Choi, I., et al., Cloning and characterization of a human electrogenic Na+-HCO-3 cotransporter isoform (hhNBC). Am J Physiol, 1999. 276(3 Pt 1): p. C576-84.

18. Bevensee, M.O., et al., An electrogenic $\mathrm{Na}(+)-\mathrm{HCO}(-)(3)$ cotransporter (NBC) with a novel COOH-terminus, cloned from rat brain. Am J Physiol Cell Physiol, 2000. 278(6): p. C1200-11.

19. Sciortino, C.M. and M.F. Romero, Cation and voltage dependence of rat kidney electrogenic $\mathrm{Na}(+)-H C O(-)(3)$ cotransporter, rkNBC, expressed in oocytes. Am J Physiol, 1999. 277(4 Pt 2): p. F611-23.

20. Muller-Berger, S., et al., The renal Na-HCO3-cotransporter expressed in Xenopus laevis oocytes: change in stoichiometry in response to elevation of cytosolic Ca2+ concentration. Pflugers Arch, 2001. 442(5): p. 718-28.

21. Gross, E., et al., The stoichiometry of the electrogenic sodium bicarbonate cotransporter NBC1 is cell-type dependent. J Physiol, 2001. 531(Pt 3): p. 597-603.

22. Aiello, E.A., et al., Evidence for an electrogenic Na+-HCO3- symport in rat cardiac myocytes. J Physiol, 1998. 512 ( Pt 1): p. 137-48.

23. Villa-Abrille, M.C., M.G. Petroff, and E.A. Aiello, The electrogenic $\mathrm{Na}+\mathrm{HCO}-$ cotransport modulates resting membrane potential and action potential duration in cat ventricular myocytes. J Physiol, 2007. 578(Pt 3): p. 819-29.

24. Pushkin, A., et al., Cloning, characterization and chromosomal assignment of NBC4, a new member of the sodium bicarbonate cotransporter family. Biochim Biophys Acta, 2000. 1493(12): p. 215-8.

25. De Giusti, V.C., et al., Antibodies against the cardiac sodium/bicarbonate co-transporter (NBCe1) as pharmacological tools. Br J Pharmacol, 2011. 164(8): p. 1976-89.

26. Pushkin, A., et al., Mapping of the human NBC3 (SLC4A7) gene to chromosome 3p22. Genomics, 1999. 57(2): p. 321-2.

27. Pushkin, A., et al., Cloning, tissue distribution, genomic organization, and functional characterization of NBC3, a new member of the sodium bicarbonate cotransporter family. J Biol Chem, 1999. 274(23): p. 16569-75.

28. Tatishchev, S., et al., Identification of membrane topography of the electrogenic sodium bicarbonate cotransporter pNBC1 by in vitro transcription/translation. Biochemistry, 2003. 42(3): p. 755-65.

29. Choi, I., et al., An electroneutral sodium/bicarbonate cotransporter NBCn1 and associated sodium channel. Nature, 2000. 405(6786): p. 571-5.

30. Boron, W.F., Acid-base transport by the renal proximal tubule. J Am Soc Nephrol, 2006. 17(9): p. 2368-82.

31. Zhu, Q., D.W. Lee, and J.R. Casey, Novel topology in C-terminal region of the human plasma membrane anion exchanger, AE1. J Biol Chem, 2003. 278(5): p. 3112-20.

32. Boron, W.F., L. Chen, and M.D. Parker, Modular structure of sodium-coupled bicarbonate transporters. J Exp Biol, 2009. 212(Pt 11): p. 1697-706.

33. Zhu, Q., et al., NBCe1-A Transmembrane Segment 1 Lines the Ion Translocation Pathway. J Biol Chem, 2009. 284(13): p. 8918-29. 
34. De Giusti, V.C., C.D. Garciarena, and E.A. Aiello, Role of reactive oxygen species (ROS) in angiotensin II-induced stimulation of the cardiac $\mathrm{Na}+/ \mathrm{HCO} 3$ - cotransport. J Mol Cell Cardiol, 2009. 47(5): p. 716-22.

35. De Giusti, V.C., A. Orlowski, and E.A. Aiello, Angiotensin II inhibits the electrogenic Na+/HCO3cotransport of cat cardiac myocytes. J Mol Cell Cardiol, 2010. 49(5): p. 812-8.

36. Kohout, T.A. and T.B. Rogers, Angiotensin II activates the $\mathrm{Na}+\mathrm{HCO}-$ symport through a phosphoinositide-independent mechanism in cardiac cells. J Biol Chem, 1995. 270(35): p. 20432-8.

37. Wu, J., C.M. McNicholas, and M.O. Bevensee, Phosphatidylinositol 4,5-bisphosphate (PIP2) stimulates the electrogenic $\mathrm{Na} / \mathrm{HCO} 3$ cotransporter NBCe1-A expressed in Xenopus oocytes. Proc Natl Acad Sci U S A, 2009. 106(33): p. 14150-5.

38. Lagadic-Gossmann, D. and R.D. Vaughan-Jones, Coupling of dual acid extrusion in the guineapig isolated ventricular myocyte to alpha 1- and beta-adrenoceptors. J Physiol, 1993. 464: p. 49-73.

39. Gross, E., et al., Phosphorylation-induced modulation of pNBC1 function: distinct roles for the amino- and carboxy-termini. J Physiol, 2003. 549(Pt 3): p. 673-82.

40. Lagadic-Gossmann, D., K.J. Buckler, and R.D. Vaughan-Jones, Role of bicarbonate in pH recovery from intracellular acidosis in the guinea-pig ventricular myocyte. J Physiol, 1992. 458: p. 361-84.

41. Yamamoto, T., et al., Functional diversity of electrogenic $\mathrm{Na+-HCO3-cotransport} \mathrm{in} \mathrm{ventricular}$ myocytes from rat, rabbit and guinea pig. J Physiol, 2005. 562(Pt 2): p. 455-75.

42. Rothstein, E.C., et al., $\mathrm{H}(2) \mathrm{O}(2)$-induced $\mathrm{Ca}(2+)$ overload in NRVM involves ERK1/2 MAP kinases: role for an NHE-1-dependent pathway. Am J Physiol Heart Circ Physiol, 2002. 283(2): p. H598-605.

43. Bril, A., [Ion transporters and cardiovascular diseases: $\mathrm{pH}$ control or modulation of intracellular calcium concentration]. Ann Cardiol Angeiol (Paris), 2003. 52(1): p. 41-51.

44. Aiello, E.A., et al., Endothelin-1 stimulates the $\mathrm{Na}+\mathrm{Ca2}+$ exchanger reverse mode through intracellular $\mathrm{Na}+(\mathrm{Na}+\mathrm{i})$-dependent and $\mathrm{Na}+\mathrm{i}$-independent pathways. Hypertension, 2005. 45(2): p. 288-93.

45. Doggrell, S.A. and J.C. Hancox, Is timing everything? Therapeutic potential of modulators of cardiac Na(+) transporters. Expert Opin Investig Drugs, $2003.12(7):$ p. 1123-42.

46. Baartscheer, A. and M.M. van Borren, Sodium ion transporters as new therapeutic targets in heart failure. Cardiovasc Hematol Agents Med Chem, 2008. 6(4): p. 229-36.

47. Ennis, I.L., et al., Normalization of the calcineurin pathway underlies the regression of hypertensive hypertrophy induced by $\mathrm{Na}+\mathrm{H}+$ exchanger-1 (NHE-1) inhibition. Can J Physiol Pharmacol, 2007. 85(3-4): p. 301-10.

48. Theroux, P., et al., Inhibition of the sodium-hydrogen exchanger with cariporide to prevent myocardial infarction in high-risk ischemic situations. Main results of the GUARDIAN trial. Guard during ischemia against necrosis (GUARDIAN) Investigators. Circulation, 2000. 102(25): p. 3032-8.

49. Yamamoto, T., et al., Enhanced activity of ventricular $\mathrm{Na+-HCO3-cotransport} \mathrm{in} \mathrm{pressure}$ overload hypertrophy. Am J Physiol Heart Circ Physiol, 2007. 293(2): p. H1254-64.

50. Khandoudi, N., et al., Inhibition of the cardiac electrogenic sodium bicarbonate cotransporter reduces ischemic injury. Cardiovasc Res, 2001. 52(3): p. 387-96.

51. Dodgson, S.J., Why are there carbonic anhydrases in the liver? Biochem Cell Biol, 1991. 69(12): p. 761-3.

52. Henry, R.P., Multiple roles of carbonic anhydrase in cellular transport and metabolism. Annu Rev Physiol, 1996. 58: p. 523-38. 
53. Lindskog, S., Structure and mechanism of carbonic anhydrase. Pharmacol Ther, 1997. 74(1): $p$. 1-20.

54. Supuran, C.T., Carbonic anhydrases: novel therapeutic applications for inhibitors and activators. Nat Rev Drug Discov, 2008. 7(2): p. 168-81.

55. Fujikawa-Adachi, K., et al., Human mitochondrial carbonic anhydrase VB. cDNA cloning, mRNA expression, subcellular localization, and mapping to chromosome x. J Biol Chem, 1999. 274(30): p. 21228-33.

56. Alvarez, B.V., et al., Carbonic anhydrase inhibition prevents and reverts cardiomyocyte hypertrophy. J Physiol, 2007. 579(Pt 1): p. 127-45.

57. Scheibe, R.J., et al., Expression of membrane-bound carbonic anhydrases IV, IX, and XIV in the mouse heart. J Histochem Cytochem, 2006. 54(12): p. 1379-91.

58. Pastorek, J., et al., Cloning and characterization of $M N$, a human tumor-associated protein with a domain homologous to carbonic anhydrase and a putative helix-loop-helix DNA binding segment. Oncogene, 1994. 9(10): p. 2877-88.

59. Zavada, J., et al., Expression of MaTu-MN protein in human tumor cultures and in clinical specimens. Int J Cancer, 1993. 54(2): p. 268-74.

60. Peles, E., et al., The carbonic anhydrase domain of receptor tyrosine phosphatase beta is a functional ligand for the axonal cell recognition molecule contactin. Cell, 1995. 82(2): p. 25160.

61. Parent, A.S., et al., A contactin-receptor-like protein tyrosine phosphatase beta complex mediates adhesive communication between astroglial cells and gonadotrophin-releasing hormone neurones. J Neuroendocrinol, 2007. 19(11): p. 847-59.

62. Alterio, V., et al., Crystal structure of the catalytic domain of the tumor-associated human carbonic anhydrase IX. Proc Natl Acad Sci U S A, 2009. 106(38): p. 16233-8.

63. Potter, C. and A.L. Harris, Hypoxia inducible carbonic anhydrase IX, marker of tumour hypoxia, survival pathway and therapy target. Cell Cycle, 2004. 3(2): p. 164-7.

64. Potter, C.P. and A.L. Harris, Diagnostic, prognostic and therapeutic implications of carbonic anhydrases in cancer. Br J Cancer, 2003. 89(1): p. 2-7.

65. Holotnakova, T., et al., Induction of carbonic anhydrase IX by hypoxia and chemical disruption of oxygen sensing in rat fibroblasts and cardiomyocytes. Pflugers Arch, 2008. 456(2): p. 32337.

66. $\mathrm{Li}, \mathrm{X}$., et al., A novel carbonic anhydrase II binding site regulates NHE1 activity. Biochemistry, 2006. 45(7): p. 2414-24.

67. Srere, P.A., Complexes of sequential metabolic enzymes. Annu Rev Biochem, 1987. 56: p. 89124.

68. Vince, J.W. and R.A. Reithmeier, Carbonic anhydrase II binds to the carboxyl terminus of human band 3, the erythrocyte C1-/HCO3- exchanger. J Biol Chem, 1998. 273(43): p. 28430-7.

69. Vince, J.W. and R.A. Reithmeier, Identification of the carbonic anhydrase II binding site in the $\mathrm{Cl}(-) / \mathrm{HCO}(3)(-)$ anion exchanger AE1. Biochemistry, 2000. 39(18): p. 5527-33.

70. Sterling, D., R.A. Reithmeier, and J.R. Casey, A transport metabolon. Functional interaction of carbonic anhydrase II and chloride/bicarbonate exchangers. J Biol Chem, 2001. 276(51): p. 47886-94.

71. Alvarez, B.V., et al., Direct extracellular interaction between carbonic anhydrase IV and the human NBC1 sodium/bicarbonate co-transporter. Biochemistry, 2003. 42(42): p. 12321-9.

72. Loiselle, F.B., et al., Regulation of the human $\mathrm{NBC3} \mathrm{Na}+/ \mathrm{HCO} 3$ - cotransporter by carbonic anhydrase II and PKA. Am J Physiol Cell Physiol, 2004. 286(6): p. C1423-33.

73. Schueler, C., et al., Transport activity of the sodium bicarbonate cotransporter NBCe1 is enhanced by different isoforms of carbonic anhydrase. PLoS One, 2011. 6(11): p. e27167. 
74. Hallerdei, J., et al., $T$ tubules and surface membranes provide equally effective pathways of carbonic anhydrase-facilitated lactic acid transport in skeletal muscle. PLoS One, 2010. 5(12): p. e15137.

75. Scheibe, R.J., et al., Carbonic anhydrases IV and IX: subcellular localization and functional role in mouse skeletal muscle. Am J Physiol Cell Physiol, 2008. 294(2): p. C402-12.

76. Morgan, P.E., et al., Interactions of transmembrane carbonic anhydrase, CAIX, with bicarbonate transporters. Am J Physiol Cell Physiol, 2007. 293(2): p. C738-48.

77. Stockand, J.D., New ideas about aldosterone signaling in epithelia. Am J Physiol Renal Physiol, 2002. 282(4): p. F559-76.

78. Fuller, P.J. and M.J. Young, Mechanisms of mineralocorticoid action. Hypertension, 2005. 46(6): p. 1227-35.

79. Booth, R.E., J.P. Johnson, and J.D. Stockand, Aldosterone. Adv Physiol Educ, 2002. 26(1-4): p. 820.

80. Vallon, V., et al., SGK1 as a determinant of kidney function and salt intake in response to mineralocorticoid excess. Am J Physiol Regul Integr Comp Physiol, 2005. 289(2): p. R395-R401.

81. Zecevic, M., et al., SGK1 increases Na,K-ATP cell-surface expression and function in Xenopus laevis oocytes. Pflugers Arch, 2004. 448(1): p. 29-35.

82. Ganong, W.F. and P.J. Mulrow, Rate of change in sodium and potassium excretion after injection of aldosterone into the aorta and renal artery of the dog. Am J Physiol, 1958. 195(2): p. 337-42.

83. Spach, C. and D.H. Streeten, Retardation of Sodium Exchange in Dog Erythrocytes by Physiological Concentrations of Aldosterone, in Vitro. J Clin Invest, 1964. 43: p. 217-27.

84. Nomura, M., et al., Three forms of rat CYP11B genes: 11 beta-hydroxylase gene, aldosterone synthase gene, and a novel gene. J Biochem, 1993. 113(2): p. 144-52.

85. Shibata, H., et al., Regulation of aldosterone synthase cytochrome P-450 in rat adrenals by angiotensin II and potassium. Endocrinology, 1991. 128(5): p. 2534-9.

86. Tremblay, A., et al., Regulation of rat adrenal messenger RNA and protein levels for cytochrome P-450s and adrenodoxin by dietary sodium depletion or potassium intake. J Biol Chem, 1991. 266(4): p. 2245-51.

87. Casey, M.L. and P.C. MacDonald, Extraadrenal formation of a mineralocorticosteroid: deoxycorticosterone and deoxycorticosterone sulfate biosynthesis and metabolism. Endocr Rev, 1982. 3(4): p. 396-403.

88. Takeda, Y., et al., Production of aldosterone in isolated rat blood vessels. Hypertension, 1995. 25(2): p. 170-3.

89. Takeda, Y., et al., Synthesis of corticosterone in the vascular wall. Endocrinology, 1994. 135(5): p. 2283-6.

90. Hatakeyama, H., et al., Vascular aldosterone. Biosynthesis and a link to angiotensin II-induced hypertrophy of vascular smooth muscle cells. J Biol Chem, 1994. 269(39): p. 24316-20.

91. Silvestre, J.S., et al., Myocardial production of aldosterone and corticosterone in the rat. Physiological regulation. J Biol Chem, 1998. 273(9): p. 4883-91.

92. Dooley, R., B.J. Harvey, and W. Thomas, Non-genomic actions of aldosterone: from receptors and signals to membrane targets. Mol Cell Endocrinol, 2012. 350(2): p. 223-34.

93. Wehling, M., J. Kasmayr, and K. Theisen, Rapid effects of mineralocorticoids on sodium-proton exchanger: genomic or nongenomic pathway? Am J Physiol, 1991. 260(5 Pt 1): p. E719-26.

94. Christ, M., et al., Non-classical receptors for aldosterone in plasma membranes from pig kidneys. Mol Cell Endocrinol, 1994. 99(2): p. R31-4. 
95. Meyer, C., M. Christ, and M. Wehling, Characterization and solubilization of novel aldosterone-binding proteins in porcine liver microsomes. Eur J Biochem, 1995. 229(3): p. 73640.

96. De Giusti, V.C., et al., Aldosterone stimulates the cardiac $\mathrm{Na}(+) / H(+)$ exchanger via transactivation of the epidermal growth factor receptor. Hypertension, 2011. 58(5): p. 912-9.

97. Pitt, B., et al., Eplerenone, a selective aldosterone blocker, in patients with left ventricular dysfunction after myocardial infarction. N Engl J Med, 2003. 348(14): p. 1309-21.

98. Pitt, B., et al., The effect of spironolactone on morbidity and mortality in patients with severe heart failure. Randomized Aldactone Evaluation Study Investigators. N Engl J Med, 1999. 341(10): p. 709-17.

99. He, B.J., et al., Oxidation of CaMKII determines the cardiotoxic effects of aldosterone. Nat Med, 2011. 17(12): p. 1610-8.

100. Yamamuro, M., et al., Direct effects of aldosterone on cardiomyocytes in the presence of normal and elevated extracellular sodium. Endocrinology, 2006. 147(3): p. 1314-21.

101. Karmazyn, M., et al., Aldosterone increases NHE-1 expression and induces NHE-1-dependent hypertrophy in neonatal rat ventricular myocytes. Hypertension, 2003. 42(6): p. 1171-6.

102. Rude, M.K., et al., Aldosterone stimulates matrix metalloproteinases and reactive oxygen species in adult rat ventricular cardiomyocytes. Hypertension, 2005. 46(3): p. 555-61.

103. Johar, S., et al., Aldosterone mediates angiotensin II-induced interstitial cardiac fibrosis via a Nox2-containing NADPH oxidase. FASEB J, 2006. 20(9): p. 1546-8.

104. Filardo, E.J., et al., Estrogen-induced activation of Erk-1 and Erk-2 requires the $G$ proteincoupled receptor homolog, GPR30, and occurs via trans-activation of the epidermal growth factor receptor through release of HB-EGF. Mol Endocrinol, 2000. 14(10): p. 1649-60.

105. Gros, R., et al., GPR30 expression is required for the mineralocorticoid receptor-independent rapid vascular effects of aldosterone. Hypertension, 2011. 57(3): p. 442-51.

106. Ji, T.H., M. Grossmann, and I. Ji, G protein-coupled receptors. I. Diversity of receptor-ligand interactions. J Biol Chem, 1998. 273(28): p. 17299-302.

107. Hamm, H.E., The many faces of $G$ protein signaling. J Biol Chem, 1998. 273(2): p. 669-72.

108. Revankar, C.M., et al., A transmembrane intracellular estrogen receptor mediates rapid cell signaling. Science, 2005. 307(5715): p. 1625-30.

109. Filardo, E., et al., Activation of the novel estrogen receptor $\mathrm{G}$ protein-coupled receptor 30 (GPR30) at the plasma membrane. Endocrinology, 2007. 148(7): p. 3236-45.

110. Christ, M., et al., Aldosterone, not estradiol, is the physiological agonist for rapid increases in cAMP in vascular smooth muscle cells. Circulation, 1999. 99(11): p. 1485-91.

111. Deschamps, A.M. and E. Murphy, Activation of a novel estrogen receptor, GPER, is cardioprotective in male and female rats. Am J Physiol Heart Circ Physiol, 2009. 297(5): p. H1806-13.

112. Bopassa, J.C., et al., A novel estrogen receptor GPER inhibits mitochondria permeability transition pore opening and protects the heart against ischemia-reperfusion injury. Am J Physiol Heart Circ Physiol, 2010. 298(1): p. H16-23.

113. Filice, E., et al., A new membrane G protein-coupled receptor (GPR30) is involved in the cardiac effects of 17beta-estradiol in the male rat. J Physiol Pharmacol, 2009. 60(4): p. 3-10.

114. Lindsey, S.H., et al., Chronic treatment with the $G$ protein-coupled receptor 30 agonist G-1 decreases blood pressure in ovariectomized mRen2.Lewis rats. Endocrinology, 2009. 150(8): p. 3753-8.

115. Martensson, U.E., et al., Deletion of the $\mathbf{G}$ protein-coupled receptor 30 impairs glucose tolerance, reduces bone growth, increases blood pressure, and eliminates estradiol-stimulated insulin release in female mice. Endocrinology, 2009. 150(2): p. 687-98. 
116. Terada, Y., et al., Aldosterone-stimulated SGK1 activity mediates profibrotic signaling in the mesangium. J Am Soc Nephrol, 2008. 19(2): p. 298-309.

117. Bartosz, G., Reactive oxygen species: destroyers or messengers? Biochem Pharmacol, 2009. 77(8): p. 1303-15.

118. Gray, R.P., et al., Intracellular sodium and contractile function in hypertrophied human and guinea-pig myocardium. Pflugers Arch, 2001. 442(1): p. 117-23.

119. Despa, $\mathrm{S}$., et al., Intracellular $\mathrm{Na}(+)$ concentration is elevated in heart failure but $\mathrm{Na} / \mathrm{K}$ pump function is unchanged. Circulation, 2002. 105(21): p. 2543-8.

120. Despa, S., et al., Intracellular [Na+] and $\mathrm{Na}+$ pump rate in rat and rabbit ventricular myocytes. J Physiol, 2002. 539(Pt 1): p. 133-43.

121. Verdonck, F., et al., Intracellular $\mathrm{Na}+$ and altered $\mathrm{Na}+$ transport mechanisms in cardiac hypertrophy and failure. J Mol Cell Cardiol, 2003. 35(1): p. 5-25.

122. Verdonck, F., et al., Increased $\mathrm{Na}+$ concentration and altered $\mathrm{Na} / \mathrm{K}$ pump activity in hypertrophied canine ventricular cells. Cardiovasc Res, 2003. 57(4): p. 1035-43.

123. Abuladze, N., et al., Molecular cloning, chromosomal localization, tissue distribution, and functional expression of the human pancreatic sodium bicarbonate cotransporter. J. Biol. Chem., 1998. 273(28): p. 17689-95.

124. Amlal, H., C.E. Burnham, and M. Soleimani, Characterization of $\mathrm{Na}^{+/} \mathrm{HCO}_{3}^{-}$cotransporter isoform NBC-3 [published erratum appears in Am J Physiol 1999 Sep;277(3 Pt 2):following table of contents]. Am. J. Physiol., 1999. 276(6 Pt 2): p. F903-13.

125. Pushkin, A., et al., Cloning, tissue distribution, genomic organization, and functional characterization of NBC3, a new member of the sodium bicarbonate cotransporter family. J. Biol. Chem., 1999. 274(23): p. 16569-16575.

126. Pushkin, A., et al., NBC3 expression in rabbit collecting duct: colocalization with vacuolar $\mathrm{H}^{+}$ATPase. Am. J. Physiol., 1999. 277(6 Pt 2): p. F974-981.

127. Yip, K.P., et al., Apical $\mathrm{H}^{+} /$base transporters mediating bicarbonate absorption and $\mathrm{pH}_{i}$ regulation in the OMCD. Am. J. Physiol. Renal Physiol., 2002. 283(5): p. F1098-104.

128. Vorum, $\mathrm{H}$. , et al., Immunolocalization of electroneutral $\mathrm{Na}^{+}-\mathrm{HCO}_{3}{ }^{-}$cotransporter in rat kidney. Am. J. Physiol. Renal Physiol., 2000. 279(5): p. F901-9.

129. Roos, A. and W.F. Boron, Intracellular pH. Physiol Rev, 1981. 61(2): p. 296-434.

130. Kanaan, A., et al., Effect of chronic elevated carbon dioxide on the expression of acid-base transporters in the neonatal and adult mouse. Am J Physiol Regul Integr Comp Physiol, 2007. 293(3): p. R1294-302.

131. Ch'en, F.F., et al., S0859, an N-cyanosulphonamide inhibitor of sodium-bicarbonate cotransport in the heart. Br J Pharmacol, 2008. 153(5): p. 972-82.

132. Avkiran, M., Blowing off acid: a new tool to study Na+/HCO3- co-transport. Br J Pharmacol, 2008. 153(5): p. 844-5.

133. Morgan, P.E., et al., Silencing of sodium/hydrogen exchanger in the heart by direct injection of naked siRNA. J Appl Physiol, 2011. 111(2): p. 566-72.

134. Villa-Abrille, M.C., et al., Silencing of cardiac mitochondrial NHE1 prevents mitochondrial permeability transition pore opening. Am J Physiol Heart Circ Physiol, 2011. 300(4): p. H123751.

135. Biemesderfer, D., et al., NHE3: a Na+/H+ exchanger isoform of renal brush border. Am J Physiol, 1993. 265(5 Pt 2): p. F736-42.

136. Goyal, S., S. Mentone, and P.S. Aronson, Immunolocalization of NHE8 in rat kidney. Am J Physiol Renal Physiol, 2005. 288(3): p. F530-8.

137. Goyal, S., G. Vanden Heuvel, and P.S. Aronson, Renal expression of novel $\mathrm{Na}+/ \mathrm{H}+$ exchanger isoform NHE8. Am J Physiol Renal Physiol, 2003. 284(3): p. F467-73. 
138. Kanaan, A., et al., Effect of chronic elevated carbon dioxide on the expression of acid-base transporters in the neonatal and adult mouse. Am. J. Physiol. Regul. Integr. Comp. Physiol., 2007. 293(3): p. R1294-302.

139. Perez, N.G., et al., pHi regulation in myocardium of the spontaneously hypertensive rat. Compensated enhanced activity of the $\mathrm{Na(+)-H+} \mathrm{exchanger.} \mathrm{Circ} \mathrm{Res,} \mathrm{1995.} \mathrm{77(6):} \mathrm{p.} \mathrm{1192-200.}$

140. Zaniboni, M., et al., Intracellular proton mobility and buffering power in cardiac ventricular myocytes from rat, rabbit, and guinea pig. Am J Physiol Heart Circ Physiol, 2003. 285(3): p. H1236-46.

141. Ruetz, S., et al., Functional activation of plasma membrane anion exchangers occurs in a preGolgi compartment. J Cell Biol, 1993. 121(1): p. 37-48. 